\title{
البهث الناسع:
}

درجة همارسة هديري المدارس الفاصة في همافظة هسقط للإسمكين

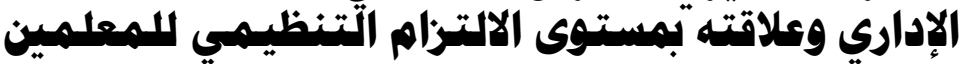

\section{:}

$$
\begin{aligned}
& \text { الباحثتش/ ساميتّ ربحي سالم حسن }
\end{aligned}
$$

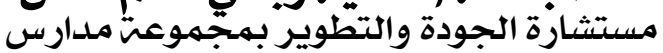

$$
\begin{aligned}
& \text { تبارك الخاصتِ فِّ مسقط سلطنت عمان } \\
& \text { دا حسام الدين السيد محمدل ابراهيم } \\
& \text { أستاذ مُشارك بك بكليت ألعلوم والآداب }
\end{aligned}
$$

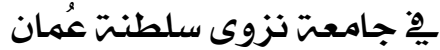





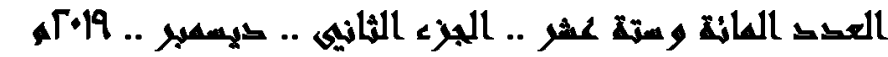
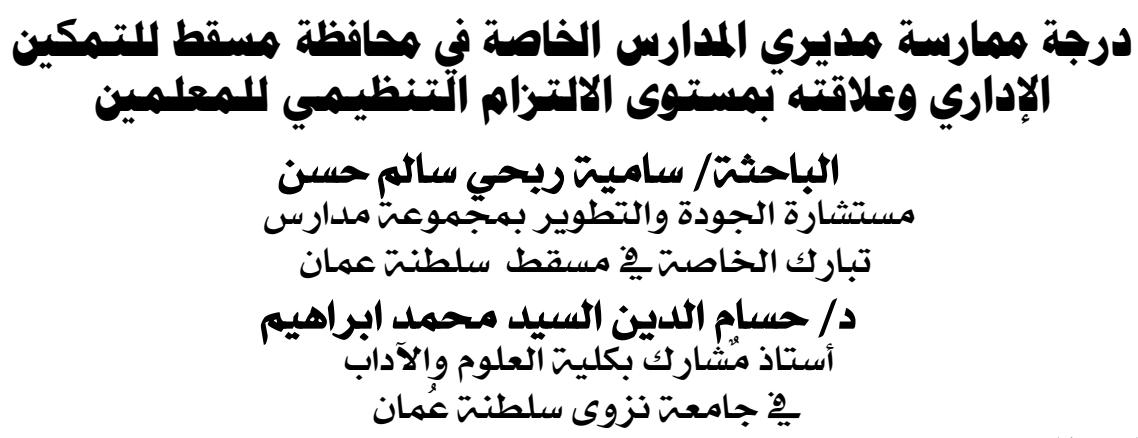

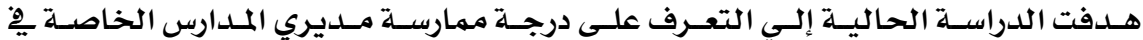

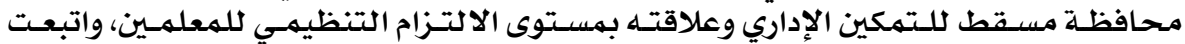

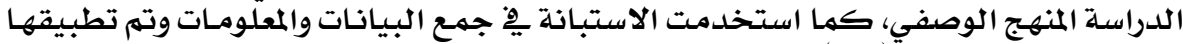

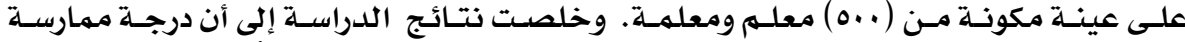

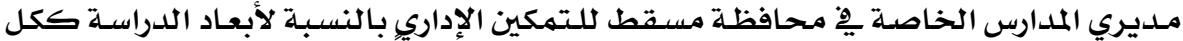

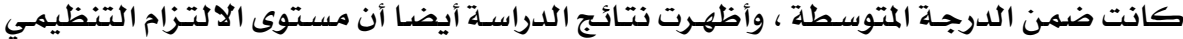

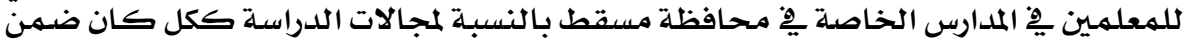

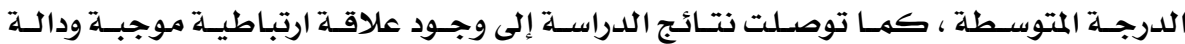

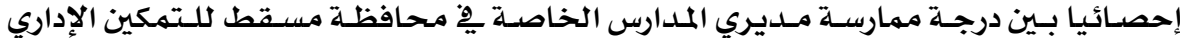

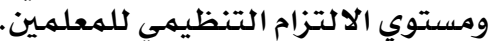

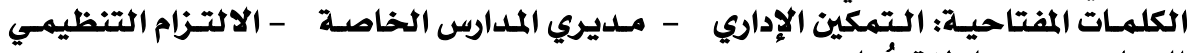
للمعلمين - سلطنة عُمان.

The Degree of Principals Practices at Administive Empowerment and its Relationship with Teachers' Commitment in Private Schools

Samia Ribhi Salem Hassan of Muscat Governorate.

Dr. Hossam El-Din El-Sayed Mohamed Ibrahim

$\underline{\text { Abstract }}$

The aim of the study is to identify the degree of Principals Practices at Administive Empowerment and its Relationship with Teachers' commitment in Private Schools of Muscat Governorate, and used questionnaire which was applied on a sample of (500) teachers. The results of the study were found the degree of Principals Practices at Administive Empowerment was medium generally, and the results also showed the level of organizational commitment of teachers was medium generally, As the results of the study found a positive correlation and statistically significant relationship between the degree of practice of private school principals in Muscat Governorate for administrative empowerment and the level of organizational commitment of teachers.

Keywords: Administive Empowerment - Principals of Private Schools - Teachers' Commitment - Sultanate of Oman . 


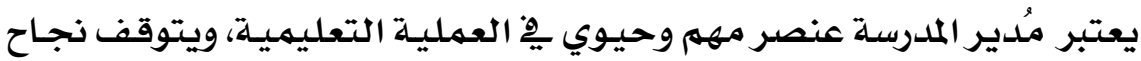

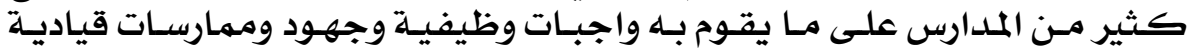

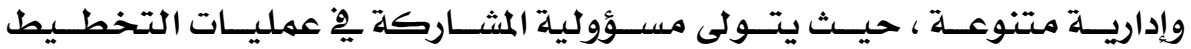

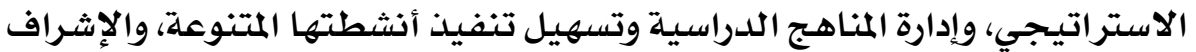

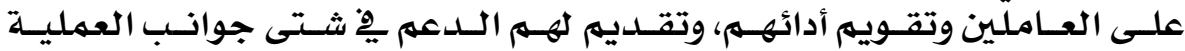
التعليمهية.

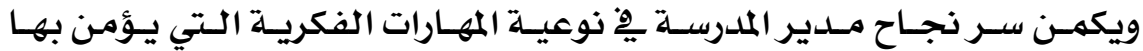

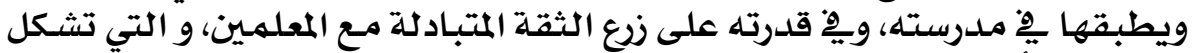

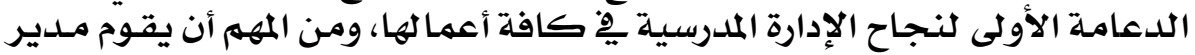

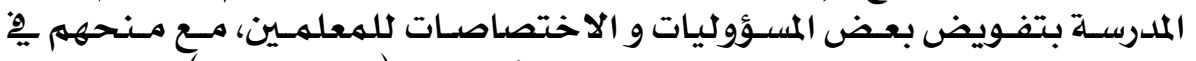

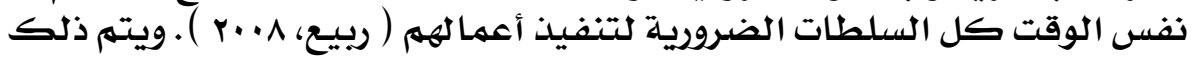

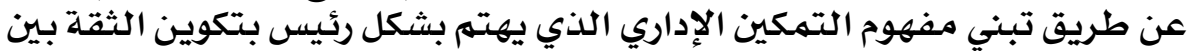

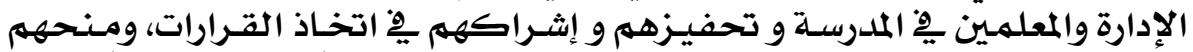

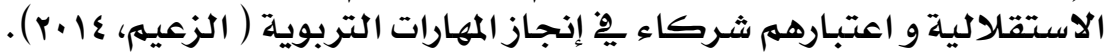

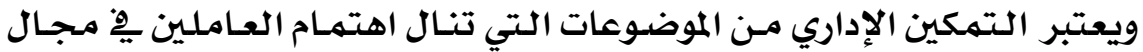

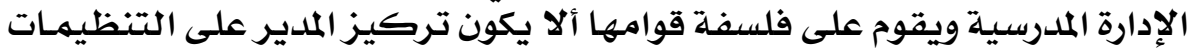

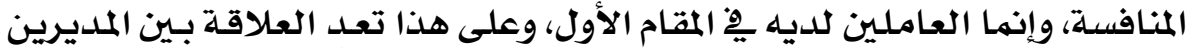

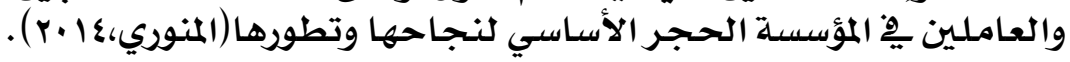

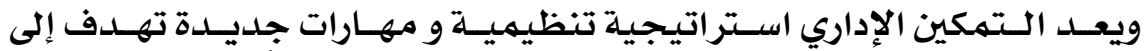

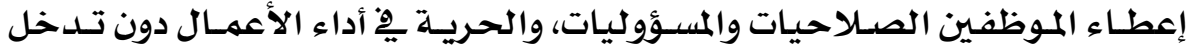

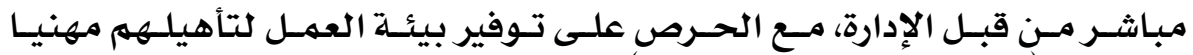

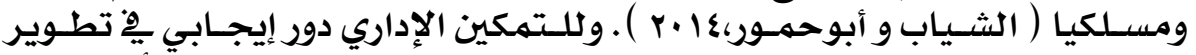

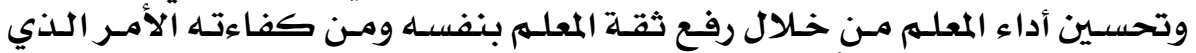

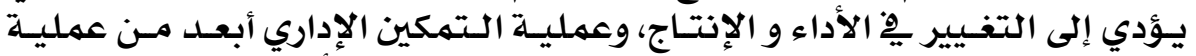

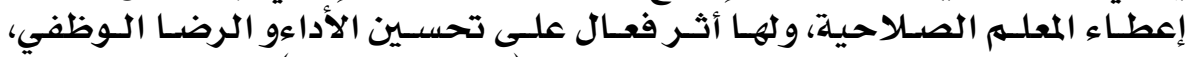

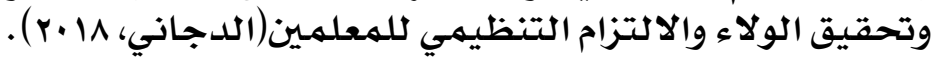

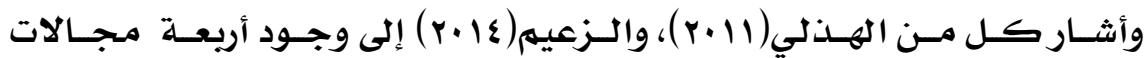

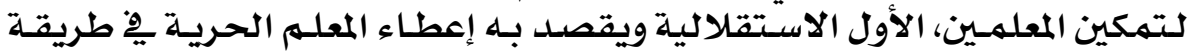

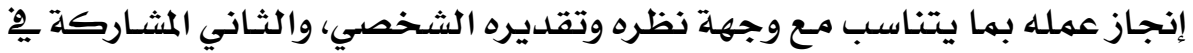

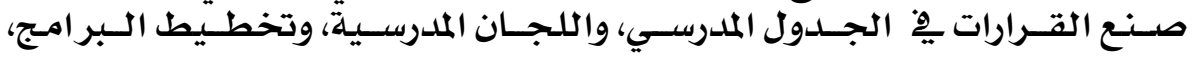

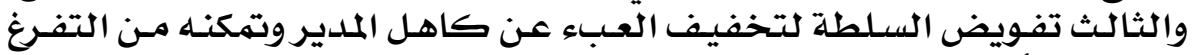

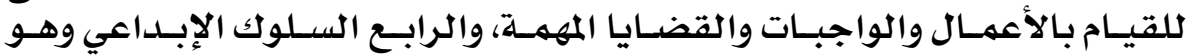

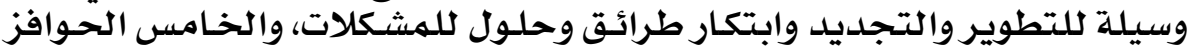

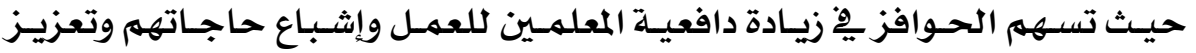




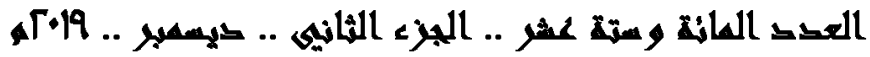

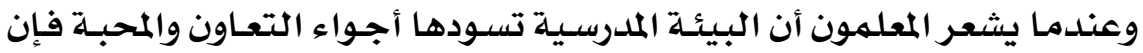

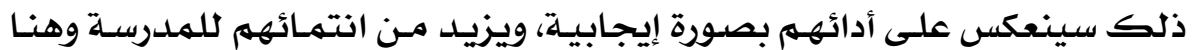

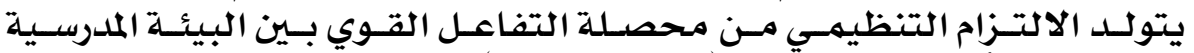

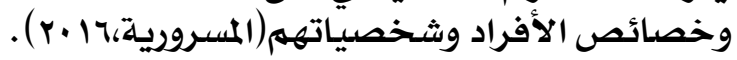

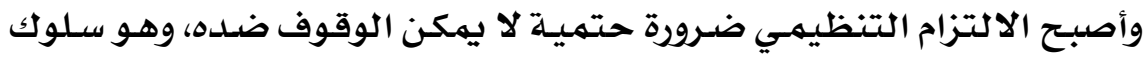

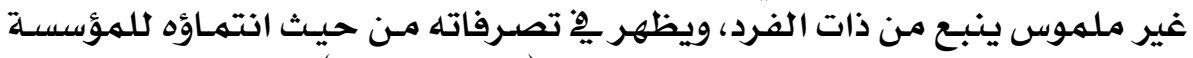

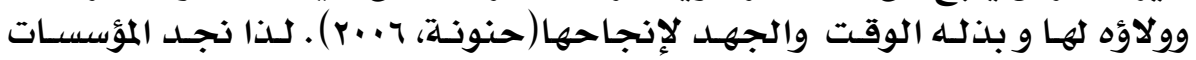

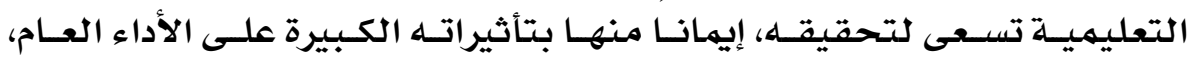

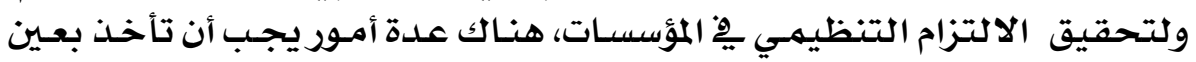

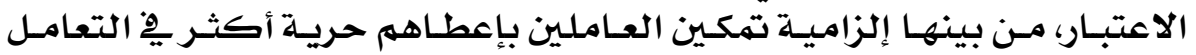

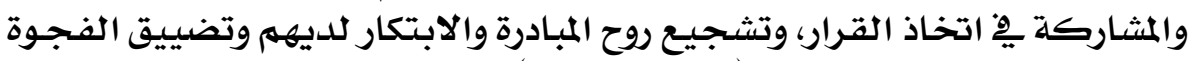

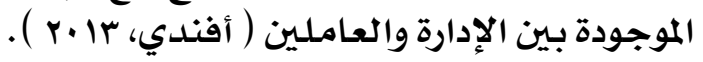

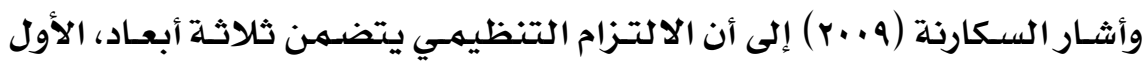

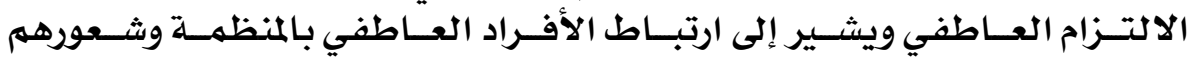

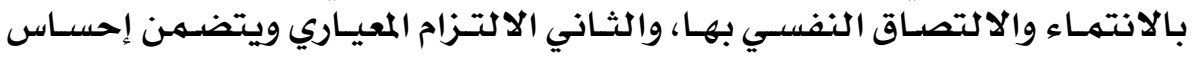

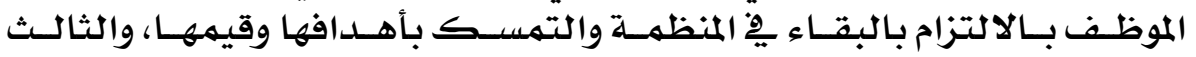

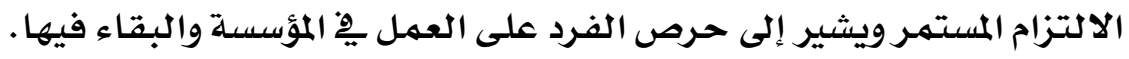

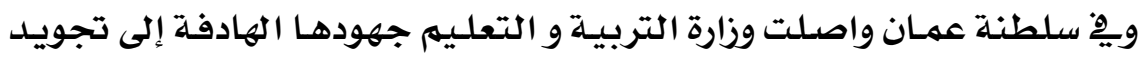

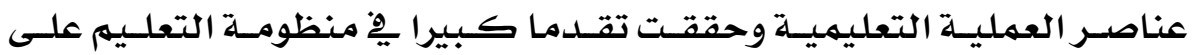

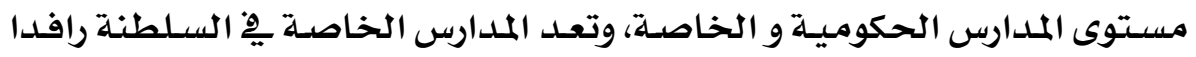

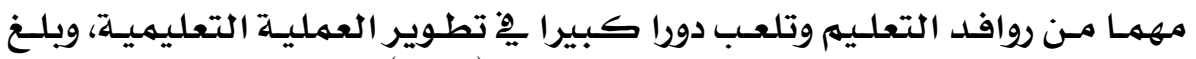

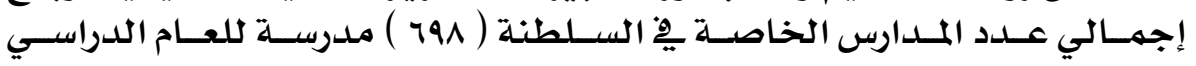

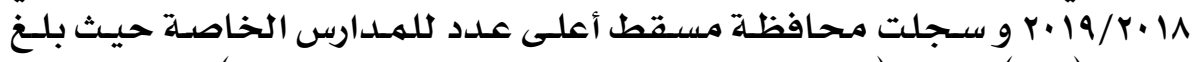

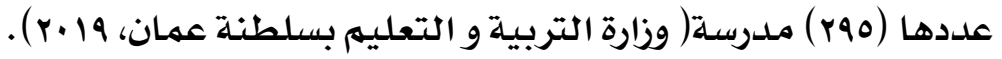

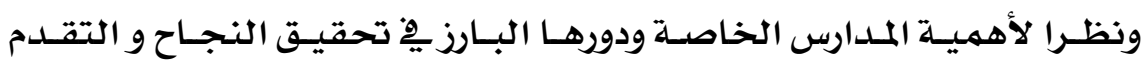

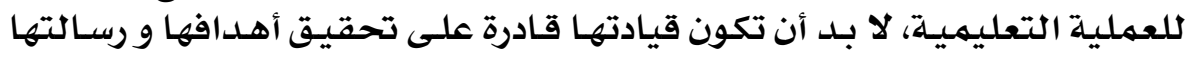

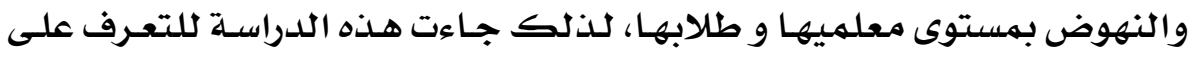

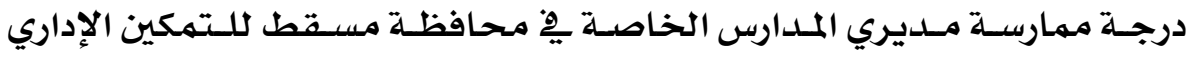
وعلاقته بمستوى الالتزام التنظيهـي للهمعلمـين.

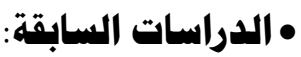

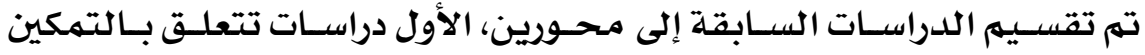

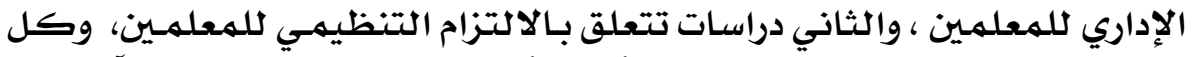

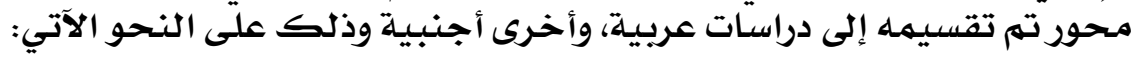




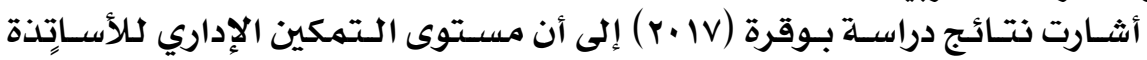

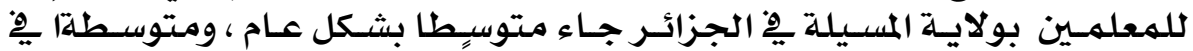

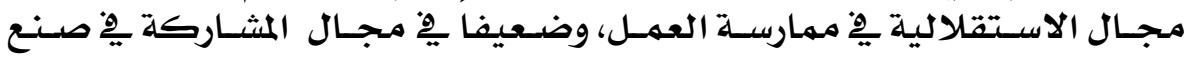

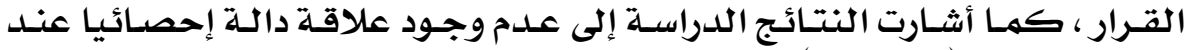

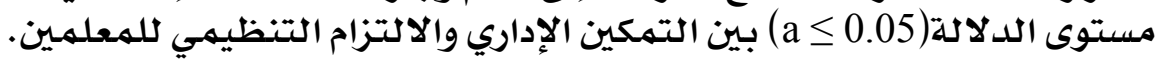

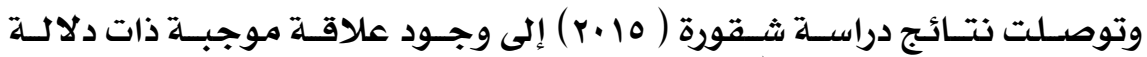
إحصائية عند مستوى دلاكله (a

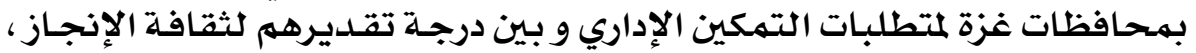

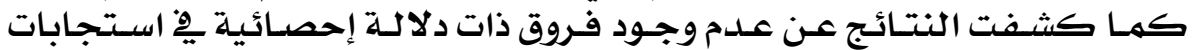

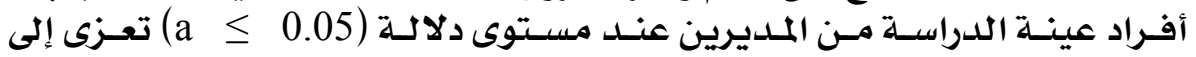

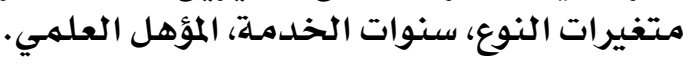

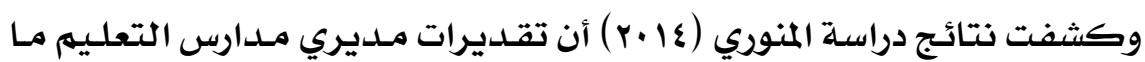

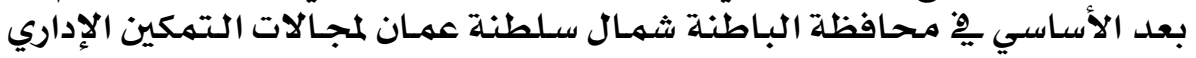

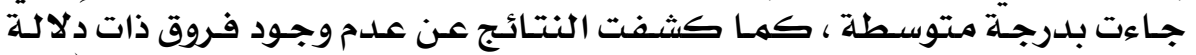

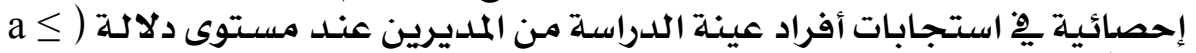

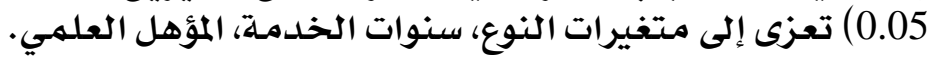

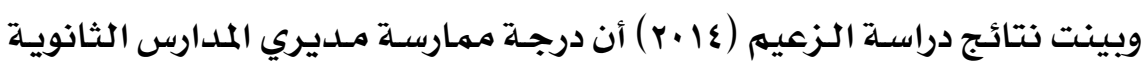

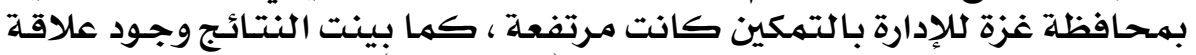

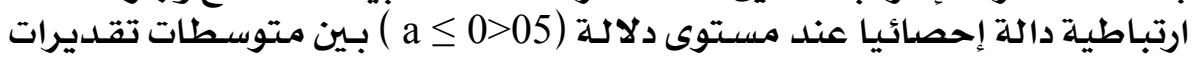

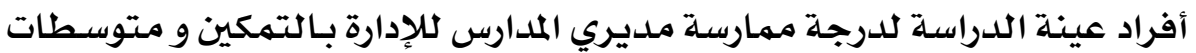

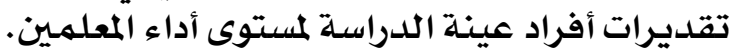



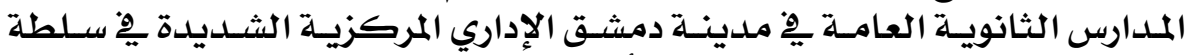

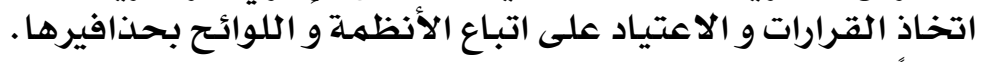

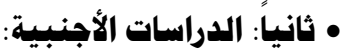

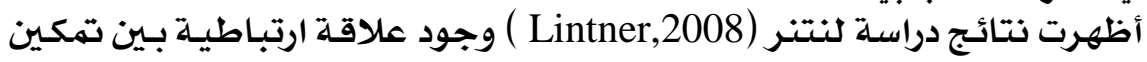

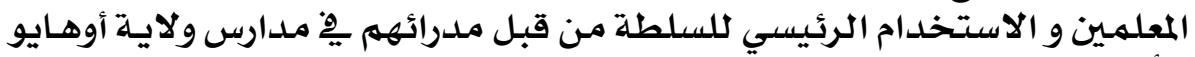
الأمـريكية.

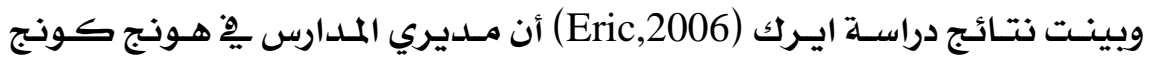

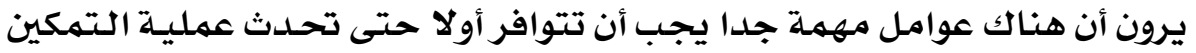

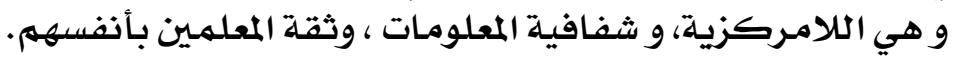

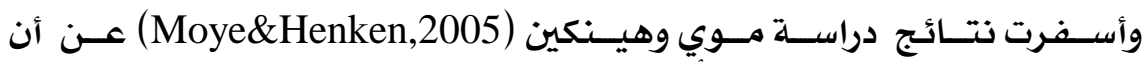

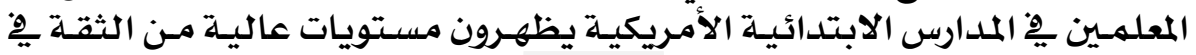




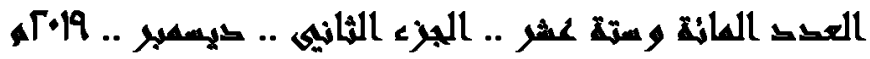

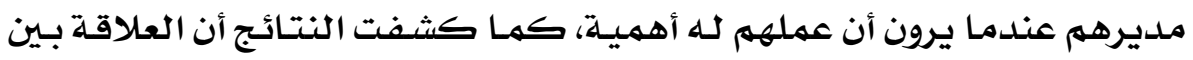

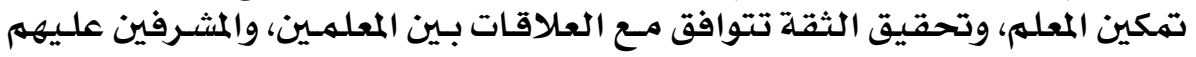

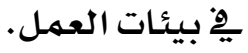



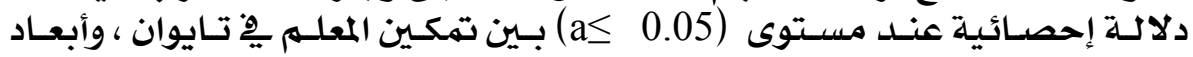
الرضا الوظيفي.

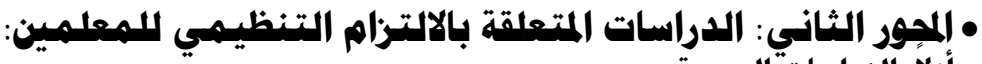

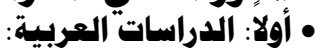

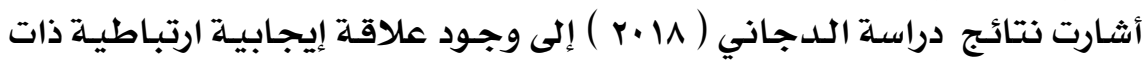

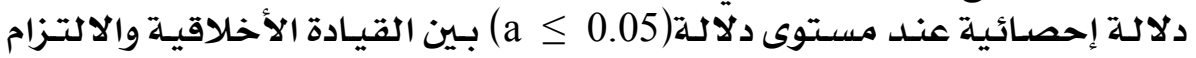

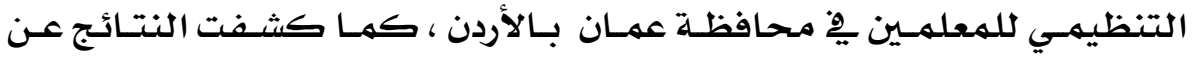

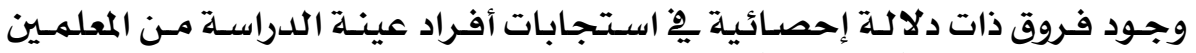

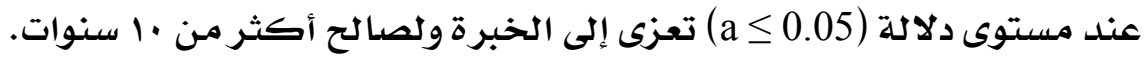

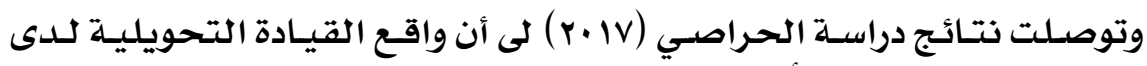

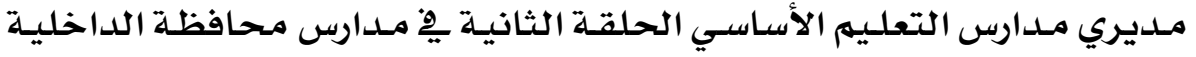

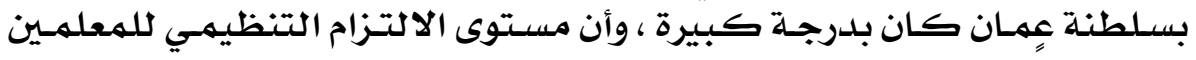

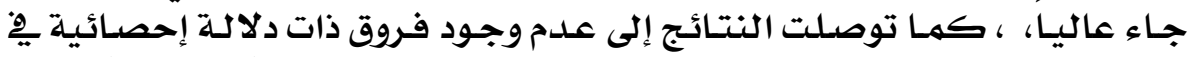

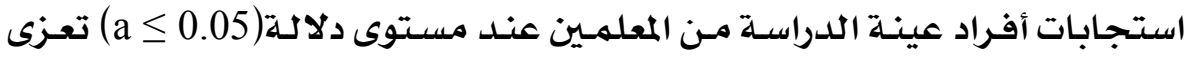

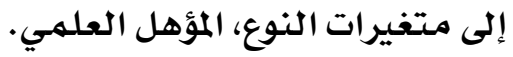

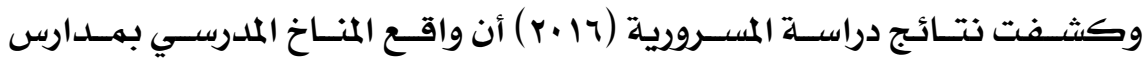

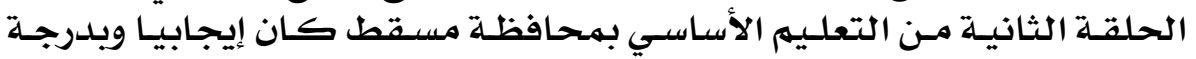

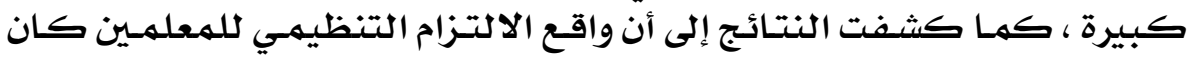
مرتفعا.

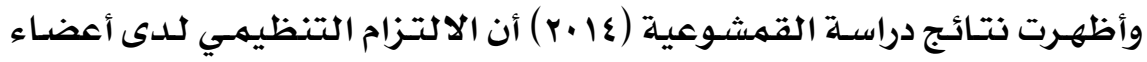

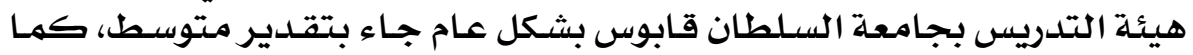

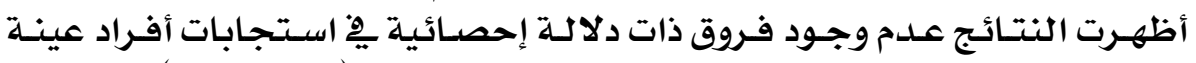

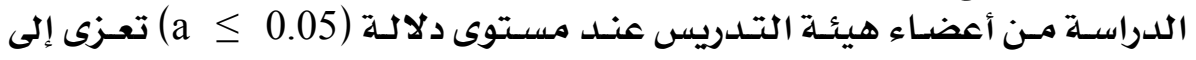
متغيرات النوع، سنوات الخبرة.

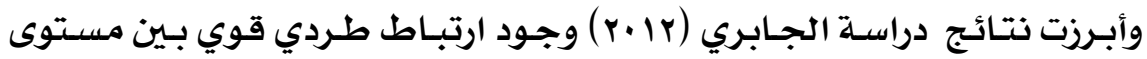

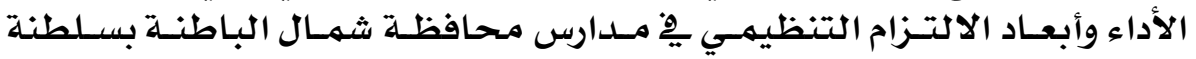

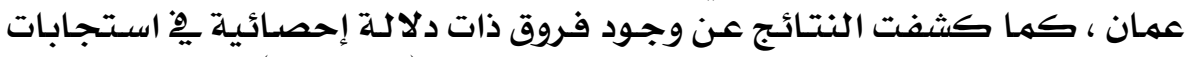

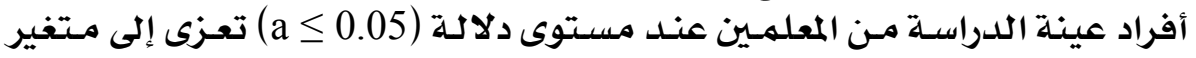

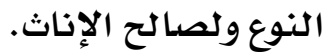

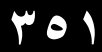




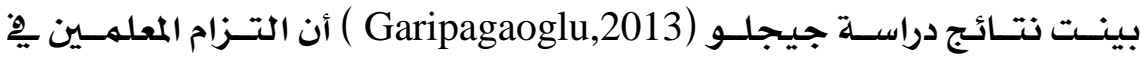

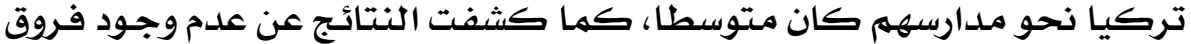

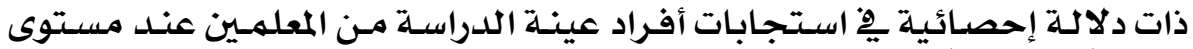

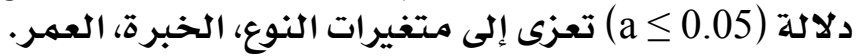

وأوضسحت نتـائج دراسـة ثـي و يـه (Yeh\&Chi,2013 ) إلى وجـود درجـة عاليـة

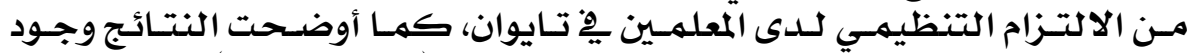

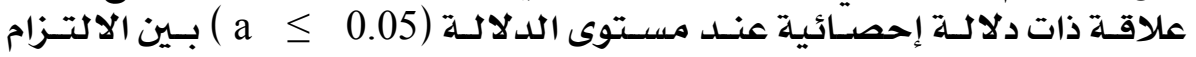
التتظيهي و فعاليـة التدريس.

وأســرت نتـائج دراسـة بـايج و رحهـن وخـان (Baig\&Rahman\&Khan,2012)

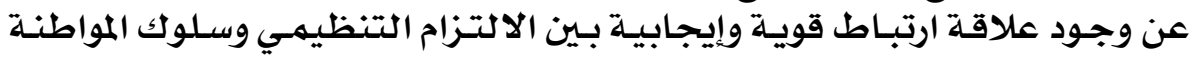

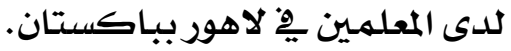

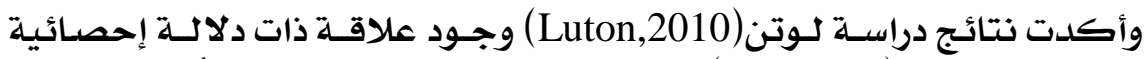

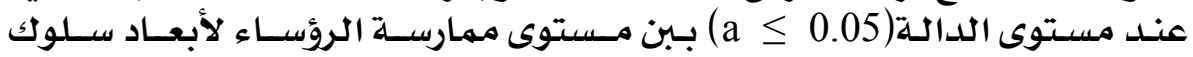

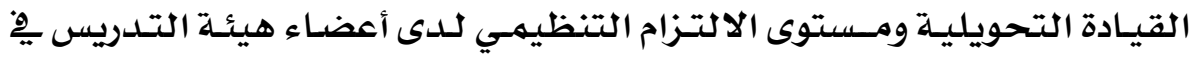

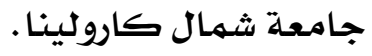

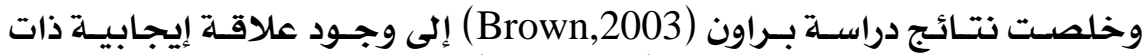

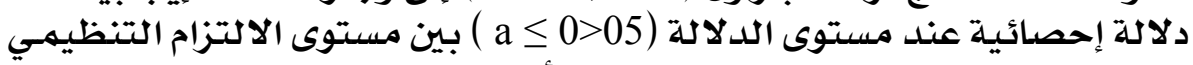

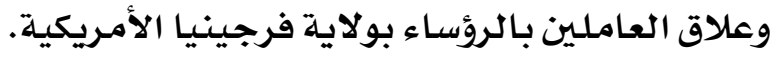

ويتضَح مـن عـرض الدراسـات السـابقة اهتهـامهـا بـالتهكين الإداري ومسـتوىى

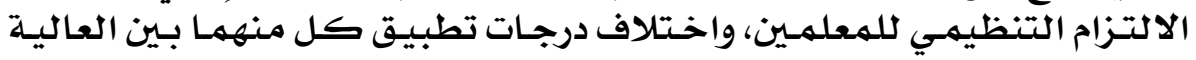

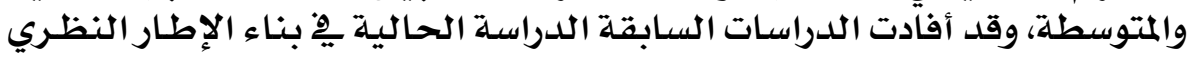

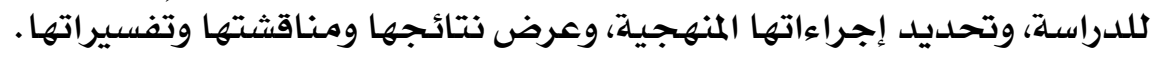

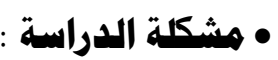

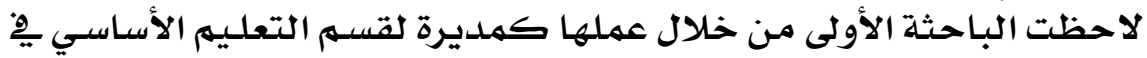

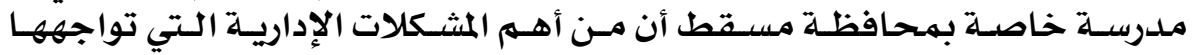

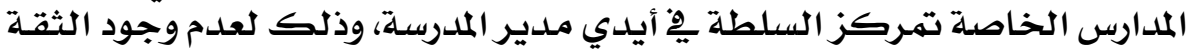

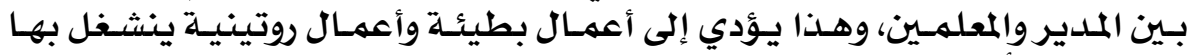

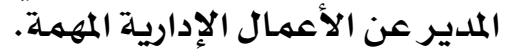

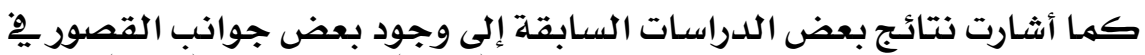

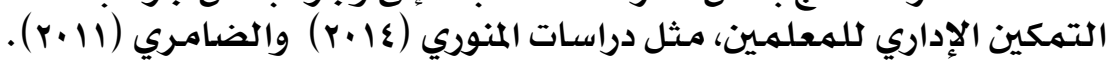

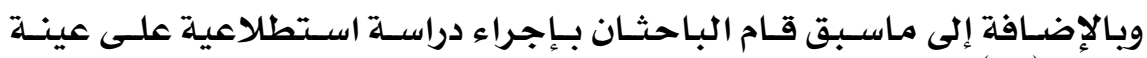

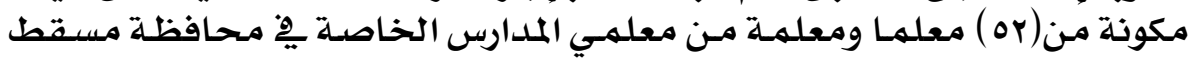

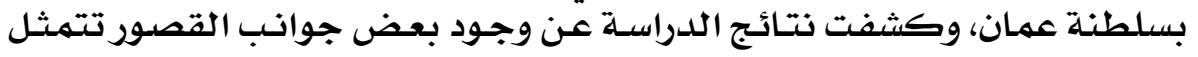




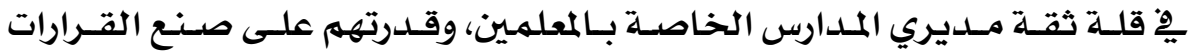

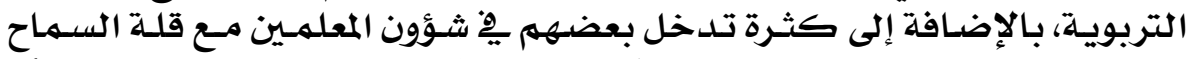

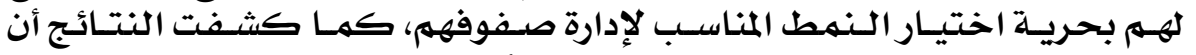

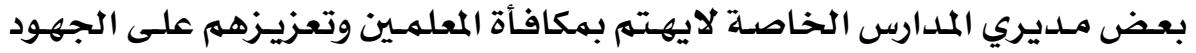

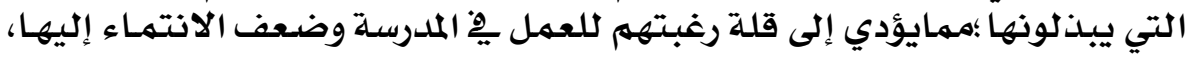

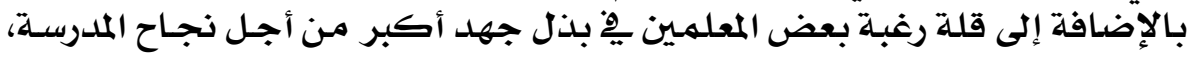

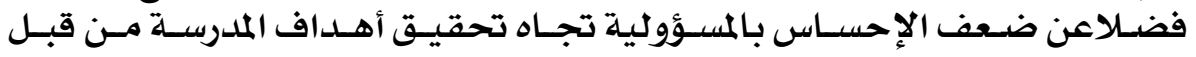
بعضهم. فئل

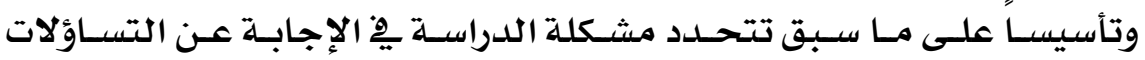
الآتية:

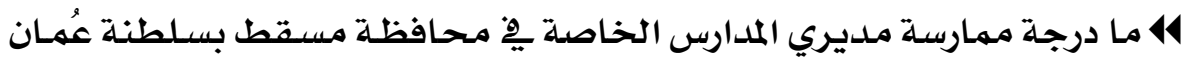

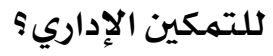

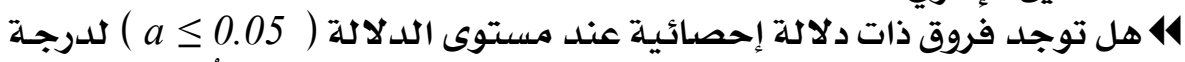

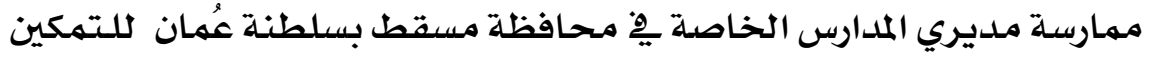

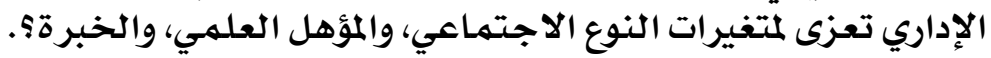

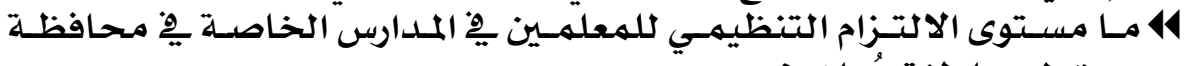

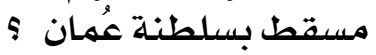

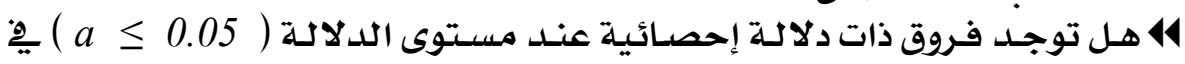

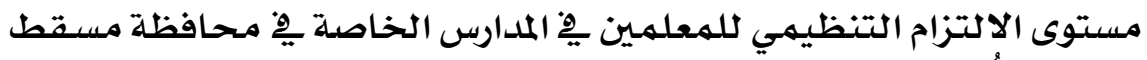

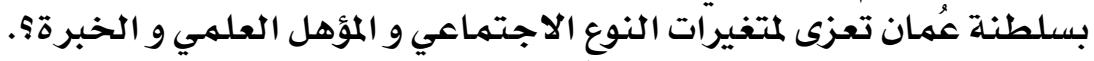

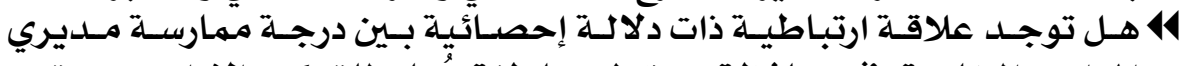

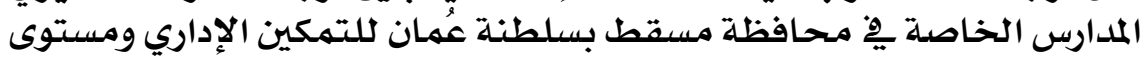

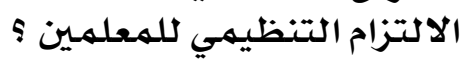

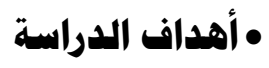

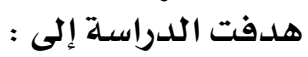

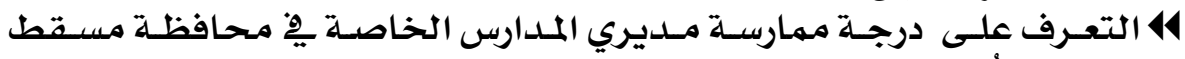
بسلطنة عُمان للتهكين الإداري.

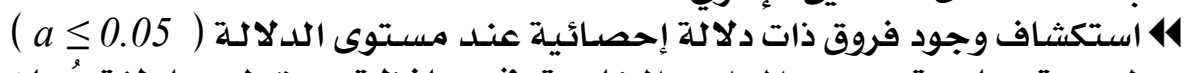

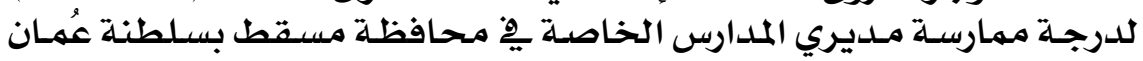

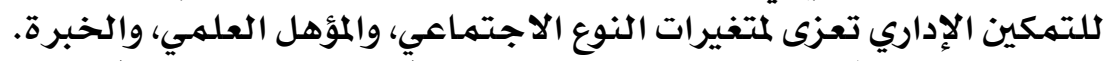

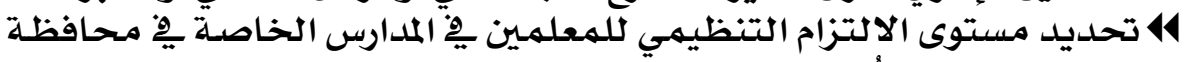
مسقط بسلطنـة عُمَان

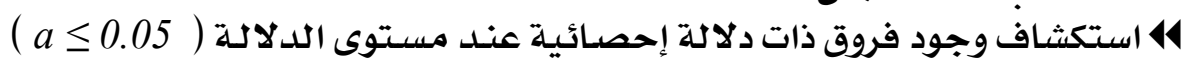

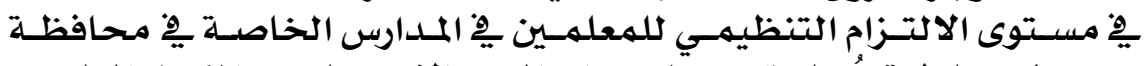

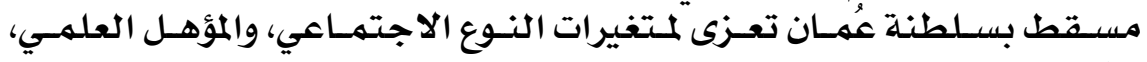
والخبرة.

\section{$\boldsymbol{Y} \odot \boldsymbol{Y}$}




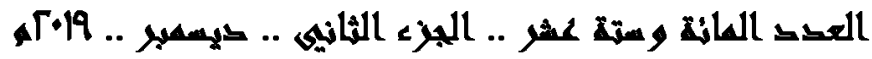

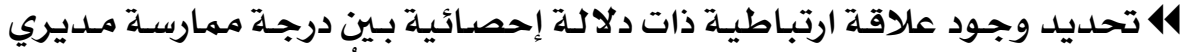

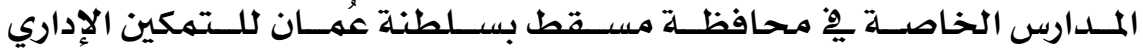

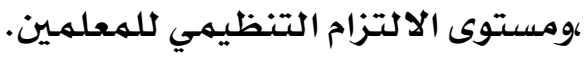

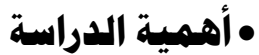

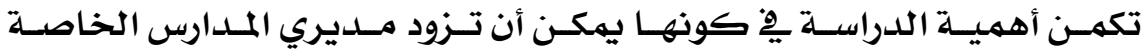

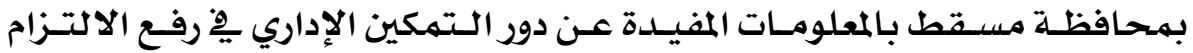

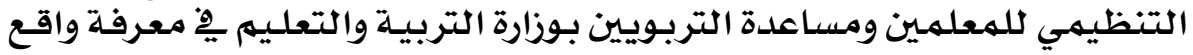

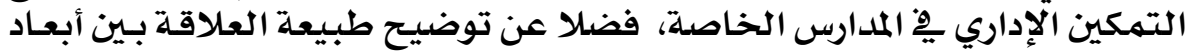

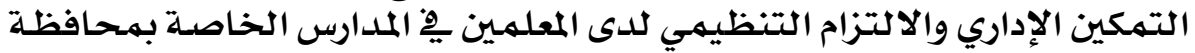
مسقط.

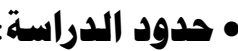

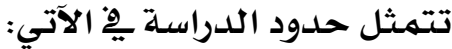

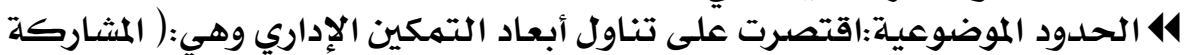

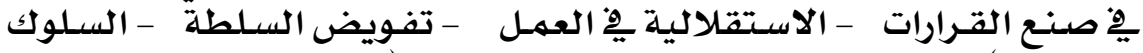

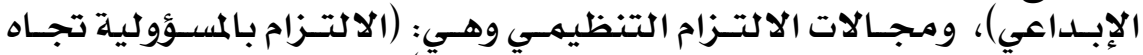

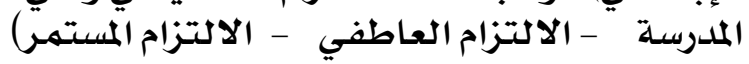

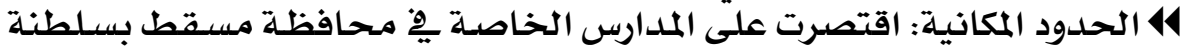
عمان.

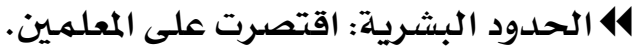

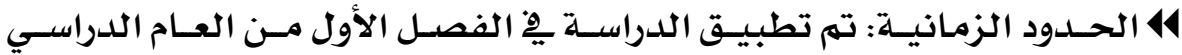
. r. r. r. r. 19

\section{• هصطالحات الدراسة}

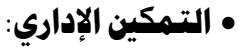

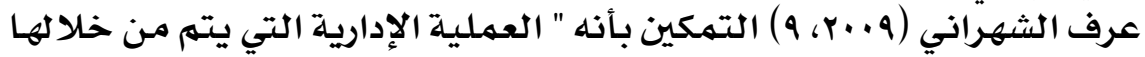

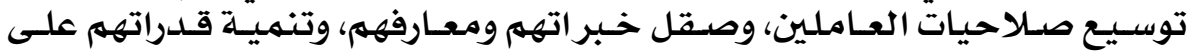

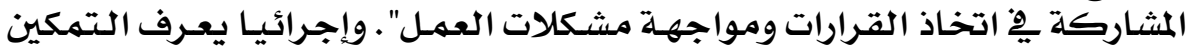

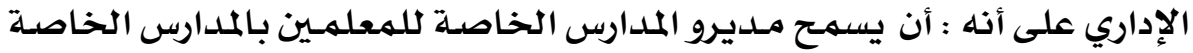

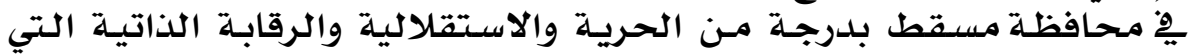

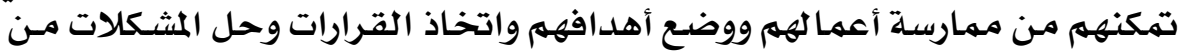

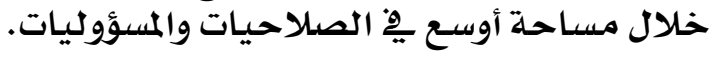

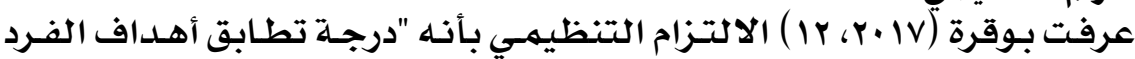

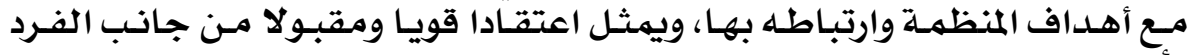

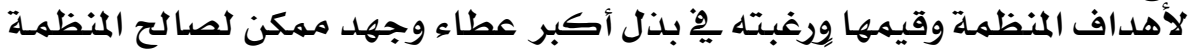

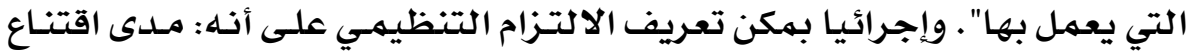

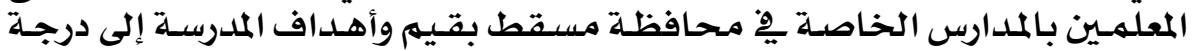

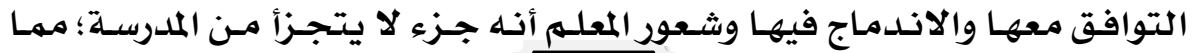




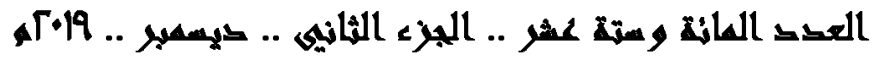

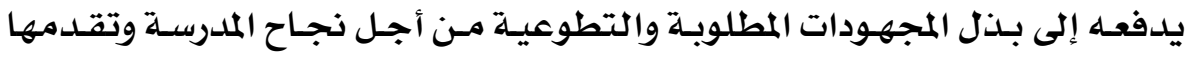

ورفاهيتها.

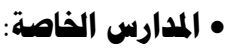

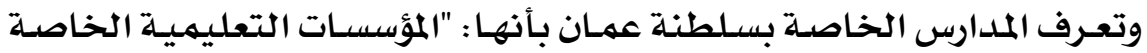

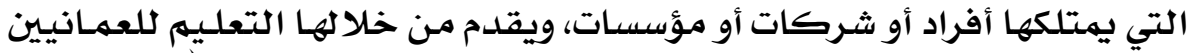

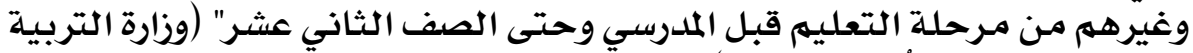

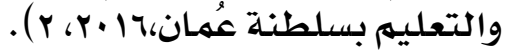

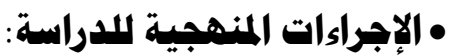
وتتضنمن تلك الإجراءاء الإتهر الآتي:

• منهج الدراسة:

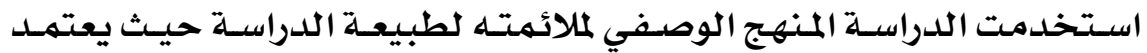

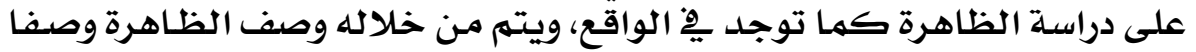

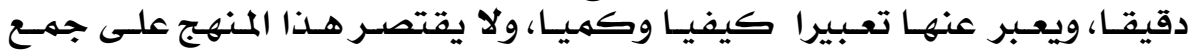

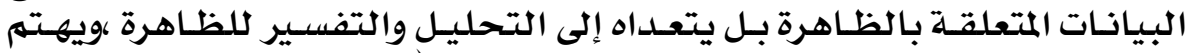

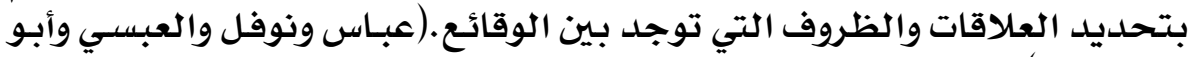

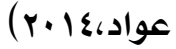

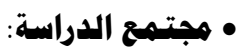

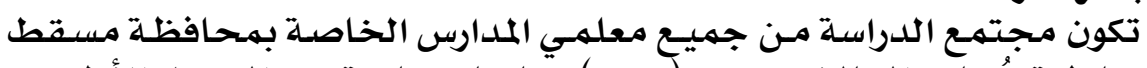

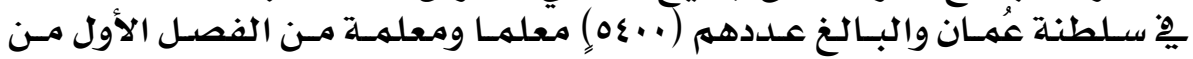

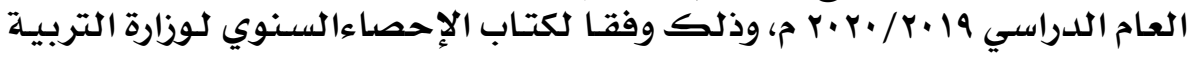

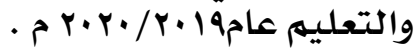
• عينة الدراسة:

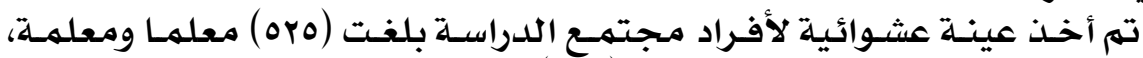

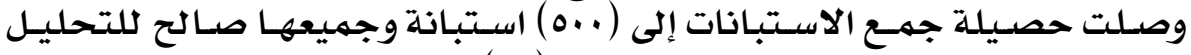

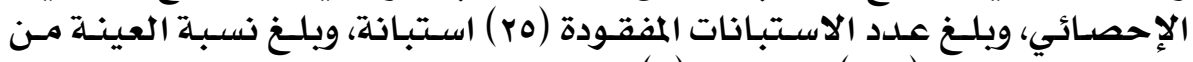

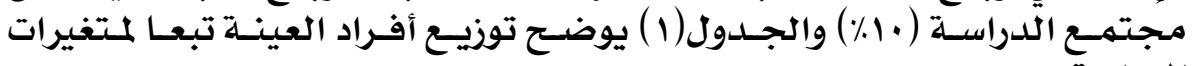
الدراسلة:

جـدول (1): توزيع عينت الدراستخ حسب المتغيرات الديموغرافيتة

\begin{tabular}{|c|c|c|c|}
\hline النسبت المئويتش/ & التكرار & الفئات & المتغير \\
\hline$v \cdot, \Lambda$ & ros & ذكر & النوع الاجتماعى \\
\hline$Y ৭, Y$ & $1 \& 4$ & انثى & \\
\hline$M, \Lambda$ & $9 \varepsilon$ & دبلوم & المؤهل العلمى \\
\hline or,A & MqE & بكالوريوس & \\
\hline$Y \wedge, \varepsilon$ & IEY & دراسات عليا & \\
\hline rr,q & 171 & ا-ه سنوات & الخبرة \\
\hline$\varepsilon 9, \cdot$ & $Y$ Yo & 1-או سنوات & \\
\hline IV, $\varepsilon$ & $\wedge \mathrm{V}$ & || سنتّ فاكثر & \\
\hline 10. & 0... & \multicolumn{2}{|c|}{ المجموع } \\
\hline
\end{tabular}




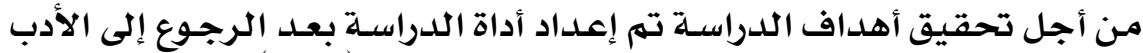

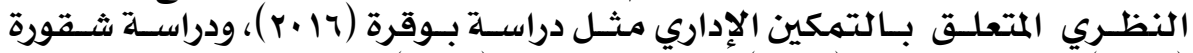

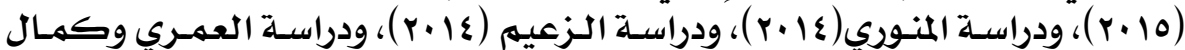

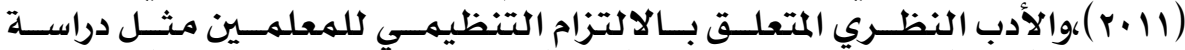

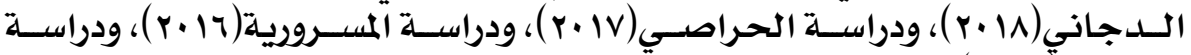

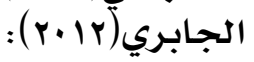

وتكونت أداة الدراسـة يخ صورتها الأوليـة مـن استبـانتين:

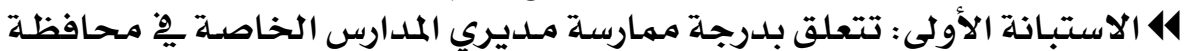

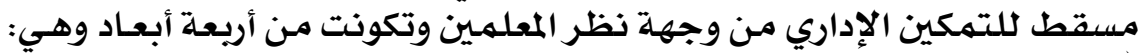

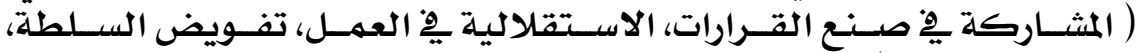

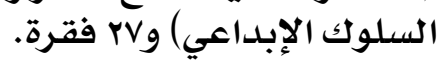

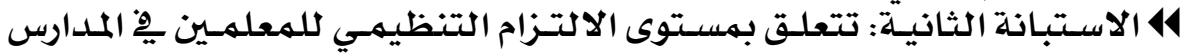

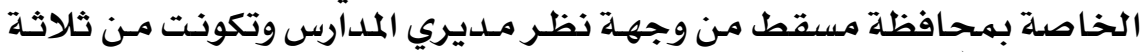

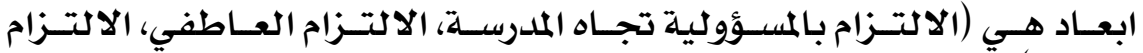

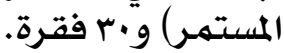
• صدق الأداة:

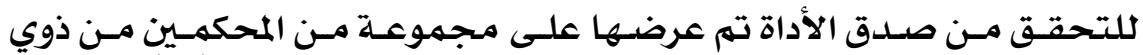

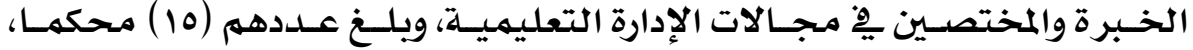

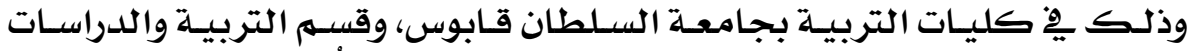

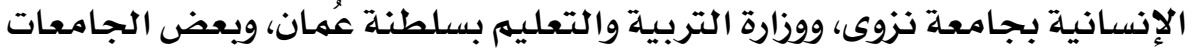

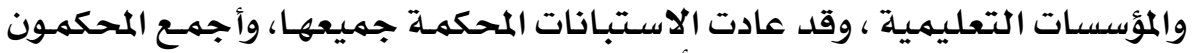

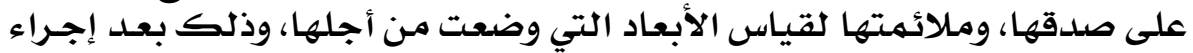

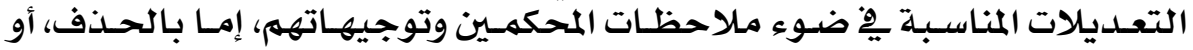

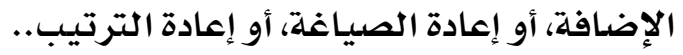

$$
\text { وتكونت الاستبانة يْ صورتها النهائية من مححورين: }
$$

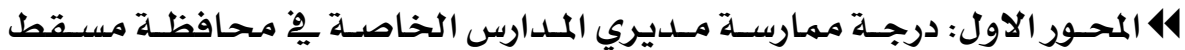

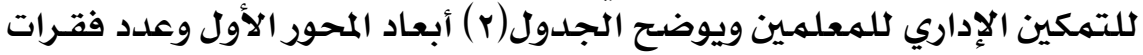

جلدول(Y) : أبعاد المحور الأول وعدد فقرات كل منها

$$
\text { كل منها. }
$$

\begin{tabular}{|c|c|c|}
\hline \multicolumn{3}{|c|}{ المحور الأول: درجت ممارست مديري المداربس الخاصت يخ محافظت مسقط للتمكين الإداري للمعلمين } \\
\hline مجموع الفقرات & البعل & م \\
\hline 5 & المشاركت فِ صنع القرارات & 1 \\
\hline 7 & الاستقلاليتيخ العمل & 2 \\
\hline 5 & تفويض السلطت & 3 \\
\hline 6 & السلوك الإبداعى & 4 \\
\hline 23 & 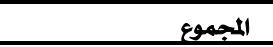 & \\
\hline
\end{tabular}




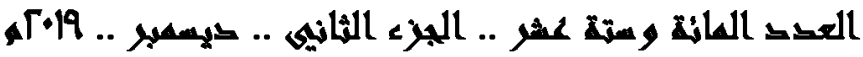

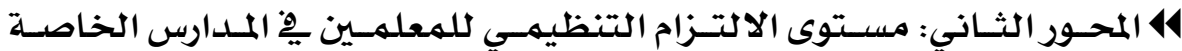

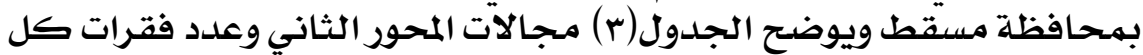

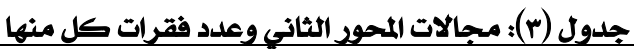

\begin{tabular}{|c|c|c|}
\hline & \multicolumn{2}{|c|}{ المحور الثانى: مستوى الالتزام التنظيمى للمعلمين - المدارس الخاصت } \\
\hline محموع الفقرات & المجال & م \\
\hline 10 & الالتزام بالمسؤوليت تجاه الملدرست & 1 \\
\hline 10 & الالتزام العاطفىى & 2 \\
\hline 10 & الالتزام المستمر & 3 \\
\hline 30 & المجموع & \\
\hline
\end{tabular}

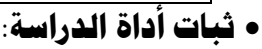

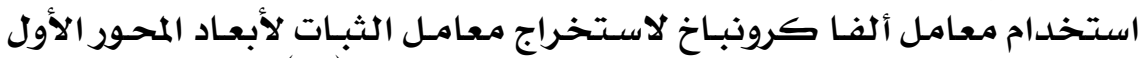

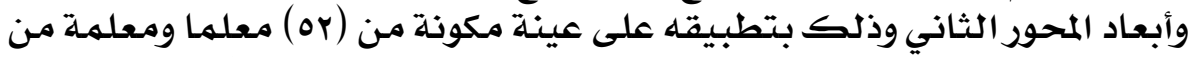

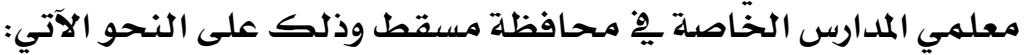

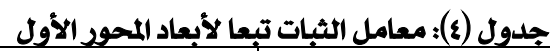

\begin{tabular}{|c|c|}
\hline قيمت ألفا كرونياخ & الأبعاد \\
\hline 0.92 & المشاركت يخ صنع القرارات \\
\hline 0.89 & تفويض السلطنة \\
\hline 0.91 & الاستقلاليت 2 العمل \\
\hline 0.96 & السلوك الابداعى \\
\hline 0.95 & الثبات الكلى \\
\hline
\end{tabular}

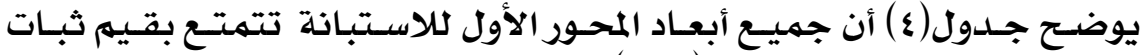

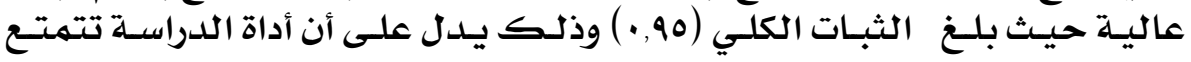

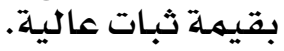
جدول (0): معامل الثبات تبعا لمجالات المحور الثاني

\begin{tabular}{|c|c|}
\hline قيمت الفا كرونباخ & المجال \\
\hline 0.96 & الالتزام بالموؤوليت تجاه المدرست \\
\hline 0.95 & الالتزام العاطفى \\
\hline 0.90 & الالتزام الستهر \\
\hline 0.96 & الثبات الكلى \\
\hline
\end{tabular}

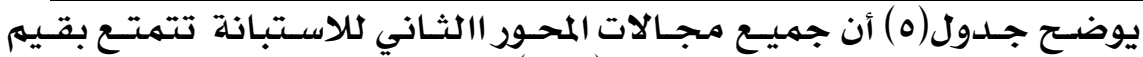

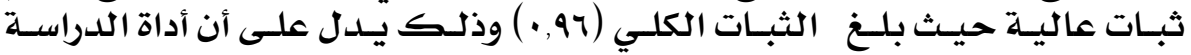
تتمتع بقيمـة ثبات عالية مالية.

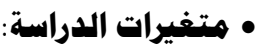
تضمنت الدراسة المتتغيرات الآتية:

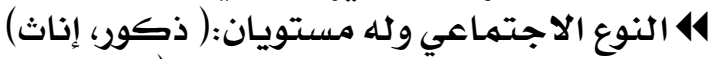

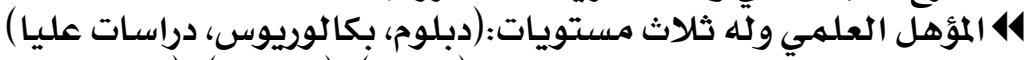

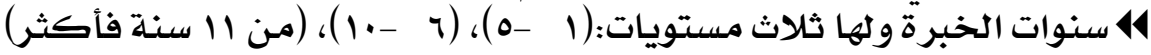

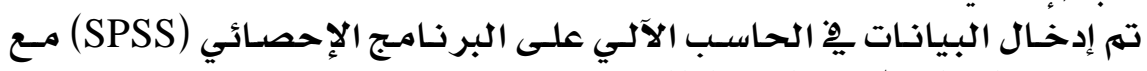
استخدام المعالجات الإحصائية التحات التالية: 


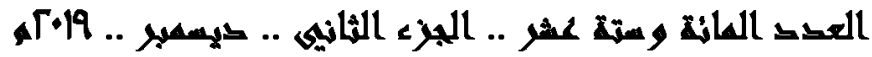

4 التوزيعـات التكراريـة، والنسـب المئويـة للتعـرف على تكرار الإجابـات لـدى أفراد

عينة الدراسلة.

414 ألفا كرو نباخ الحروابة لحساب معامل الثبات.

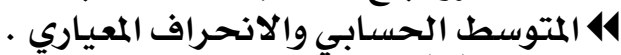

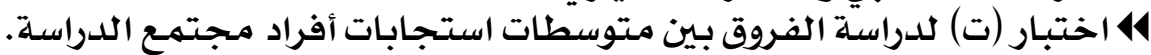

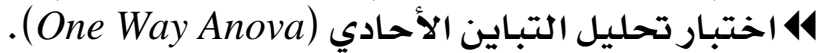

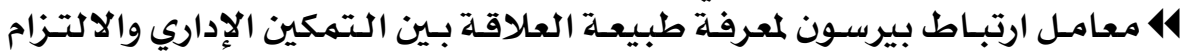
التنظيمي.

• نتائج الدراسة:

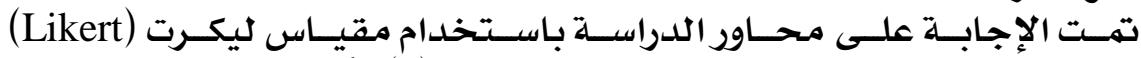

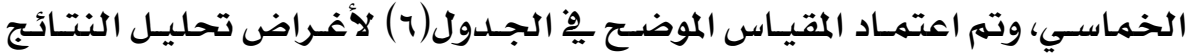

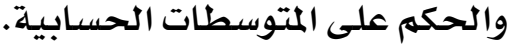

جدول(7): معيار الحكم على نتائج الدراستة

\begin{tabular}{|c|c|}
\hline درجت الاستجابة & المتوسط الحسابي(طول الخلية) \\
\hline ضعيفت & من 1 - أقل من2.34 \\
\hline متوسطت & من 2.34- أقل من3.68 \\
\hline كبيرة & من 3.68-5.00 \\
\hline
\end{tabular}

يوضح جدول(7 ) معيار الحكم على المتوسطات الحسابية لتقديرات التسات أفراد عينة

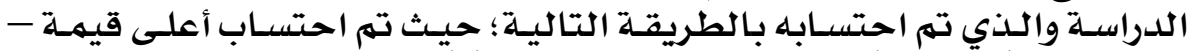

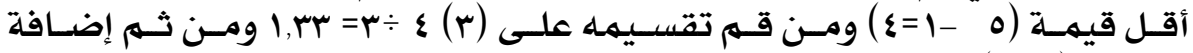

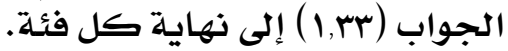

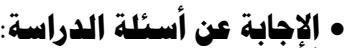

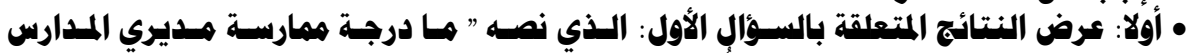

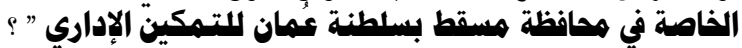

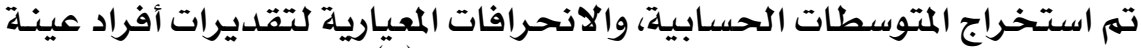

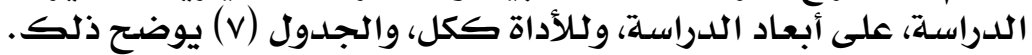

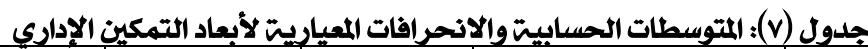

\begin{tabular}{|c|c|c|c|c|c|}
\hline اللدرجت & الانمراف المعياري & المتوسطابى & البعد & الترتيب & م \\
\hline متوسطنة & 0.92 & 3.62 & 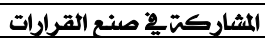 & 2 & 1 \\
\hline متوسطت & 0.89 & 3.66 & الاستقلاليت ـ2 العمل & 1 & 2 \\
\hline متوسطن & 1.01 & 3.59 & تفويض السلطت & 3 & 3 \\
\hline متوسطنة & 0.94 & 3.54 & السلوك الابداعى & 4 & 4 \\
\hline متوسطنة & 0.94 & 3.60 & \multicolumn{3}{|c|}{ المحموع الكلى } \\
\hline
\end{tabular}

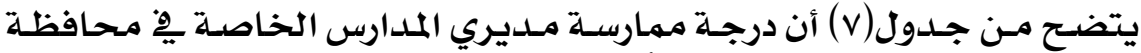

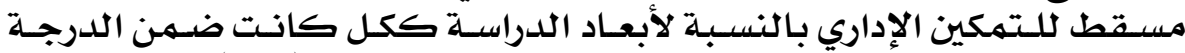

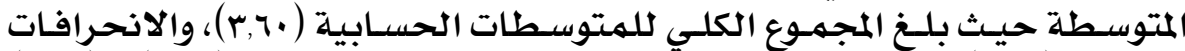

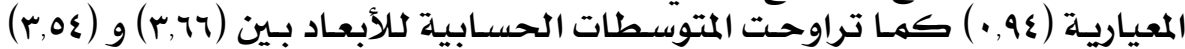

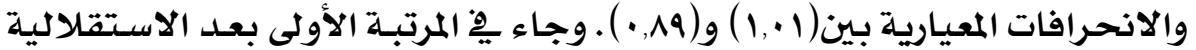




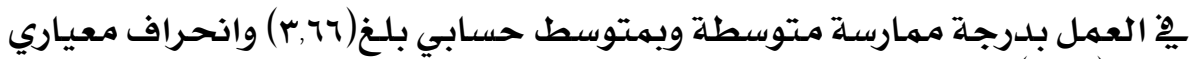

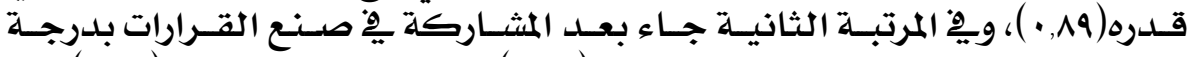

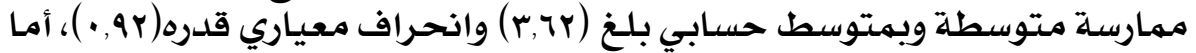

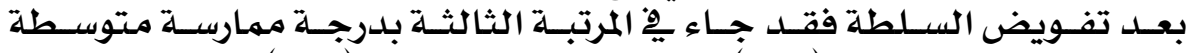

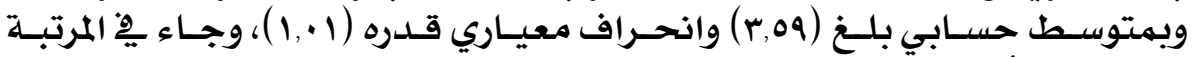

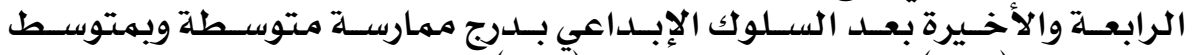

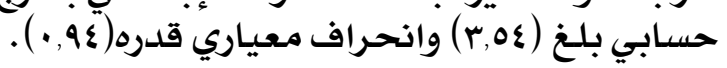

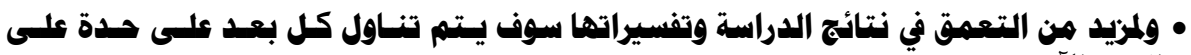

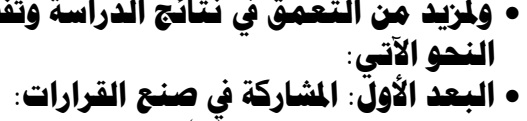

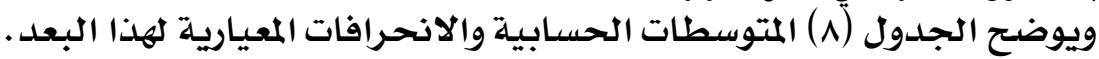

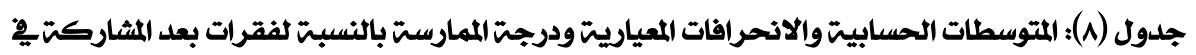

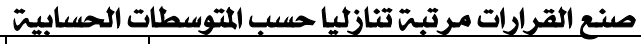

\begin{tabular}{|c|c|c|c|c|c|}
\hline اللرجةت & الالانحراف & الحسابي & الثقرة & P & الرتبت \\
\hline 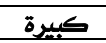 & 0.89 & 4.14 & توضيح نطاق المشاركت ف2 صنع القرارات للمعلمين & 4 & 1 \\
\hline كبيرة - كبرة & 0.94 & $\mathbf{3 . 8 0}$ & 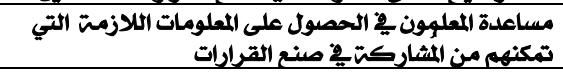 & 5 & 2 \\
\hline متوسطتة & 1.04 & 3.54 & اشراكاك المعلمين يح صنع القرارات المتعلقت بالجدول المدرسي & 2 & 3 \\
\hline متوسطة & 0.80 & 3.51 & 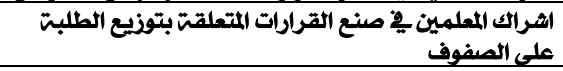 & 3 & 4 \\
\hline 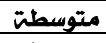 & 0.92 & 3.13 & الثقتَ بقدرات المعلمين مِ صنع القرار & 1 & 5 \\
\hline متوسطنة مترن & 0.92 & 3.62 & الم المجموع الكلرب & & \\
\hline
\end{tabular}

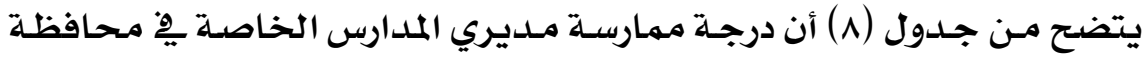

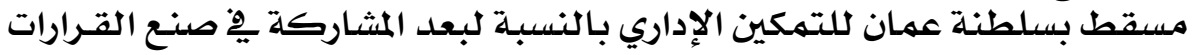

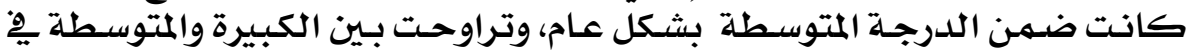

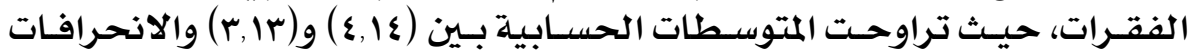

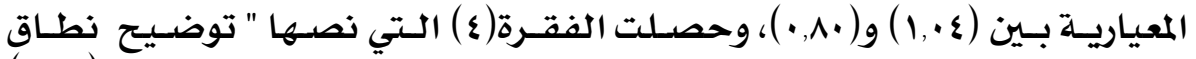

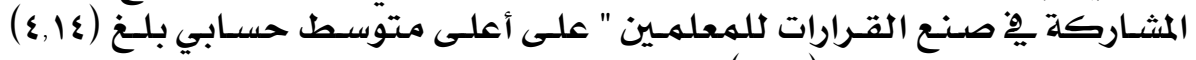

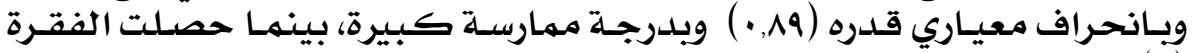

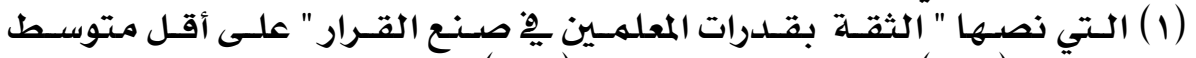

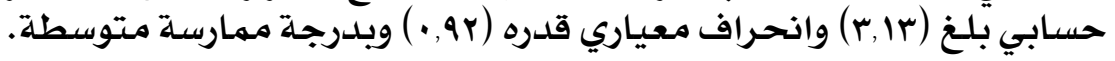

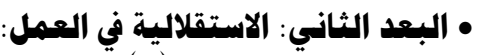

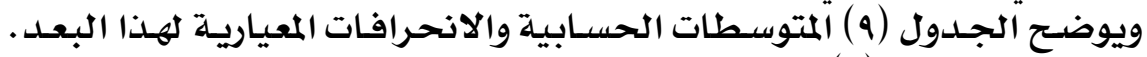

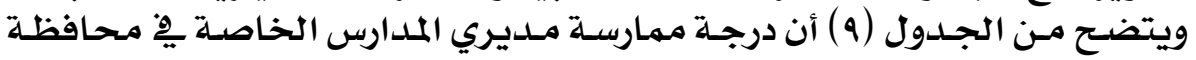

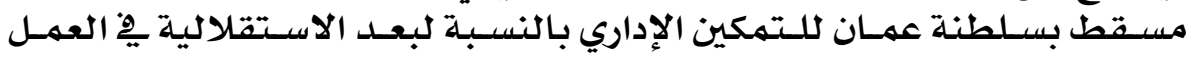

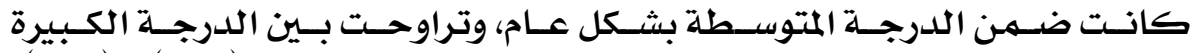

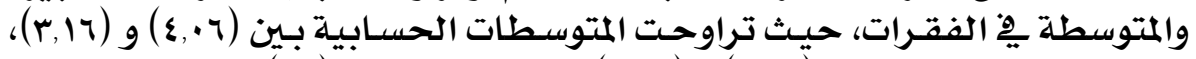

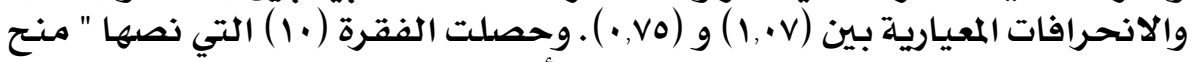

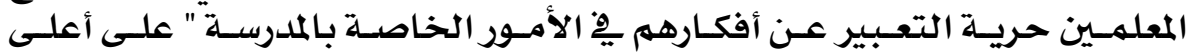

\section{$r \odot q$}




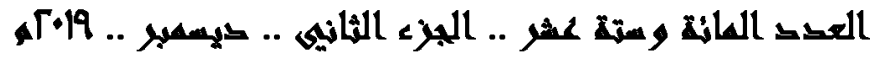

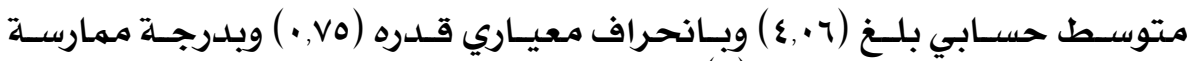

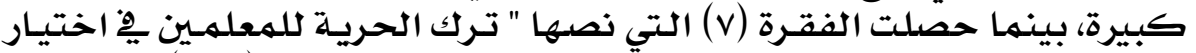

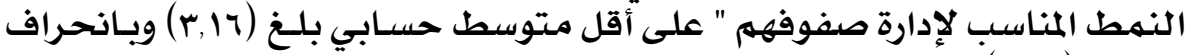

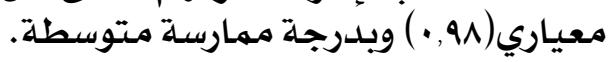

جلدول (9): المتوسطات الحسابيت والانحرافات المعياريت ودرجت الممارست بالنسبت لفقرات بعد الاستقلاليت

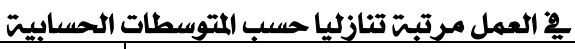

\begin{tabular}{|c|c|c|c|c|c|}
\hline الدرجتة & الالعياريري & الحسوسطى & الفقرات & $p$ & الرتبت \\
\hline كبيرة & 0.75 & 4.06 & منح المعلمين حريتيت التعبير عن أفكارهم هِ الأمور & 10 & 1 \\
\hline كبيرة & $\mathbf{0 . 8 8}$ & 4.02 & تجنب التذخل 2 ثؤون المعلمين الشخصيتة & 11 & 2 \\
\hline كبيرة & 0.80 & 3.84 & بطرقهم الخرصت للمعلمين لأداء مهامهم التربويت & 8 & 3 \\
\hline كبيرة & 0.85 & 3.71 & التغيير إِ المدرست للمعلمين لإثبات قدراتهم على إحداث & 12 & 4 \\
\hline متوسطت & 1.07 & 3.64 & تلقويم الطريتي للمعلمين يو اختيار الأسلوب المناسب & 9 & 5 \\
\hline متوسطت & 0.87 & 3.24 & تجنب إجبار المعلمين على ما لا يوافقون عليه & 6 & 6 \\
\hline متوسطت & 0.98 & 3.16 & ترفوفهم الحريت للمعلمين يخ اختيار النمط المناسب لإدارة & 7 & 7 \\
\hline متوسطت & $\mathbf{0 . 8 9}$ & 3.66 & المجموع الكلى & & \\
\hline
\end{tabular}

• البعد الثالث: تفويض السلطة:

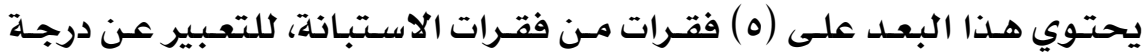

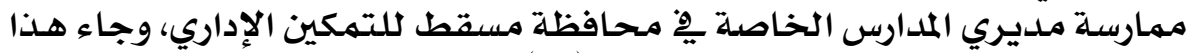

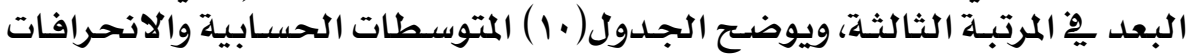
المعيارية لهذا البعد.

جلدول (.1): المتوسطات الحسابيت والانحرافات المعياريت ودرجت الممارست بالنسبت لفقرات تفويض السلطت مرتبت تنازليا حسب المتوسطات المعات الحسابيتي

\begin{tabular}{|c|c|c|c|c|c|}
\hline الدرجت & الانحراف & المستوسطي & الفقرة & p & الرتبتة \\
\hline كبيرة & 0.72 & 4.21 & 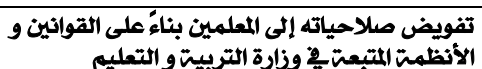 & 16 & 1 \\
\hline كبيرة & 1.00 & 3.71 & توقع النتائج الجيدة من المعلمين باستمرار & 14 & 2 \\
\hline متوسطنة & 1.03 & 3.67 & توضيح القواثين و التعليمات التي تحكم عمل & 15 & 3 \\
\hline متوسطتة & 1.10 & 3.24 & متابعت المهام المفوضت للمعلمين بشكل دوري. & 17 & 4 \\
\hline متوسطتة & 1.18 & 3.16 & 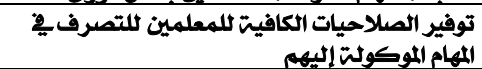 & 13 & 5 \\
\hline متوسطت & 1.01 & 3.59 & المجموع الكلى & & \\
\hline
\end{tabular}

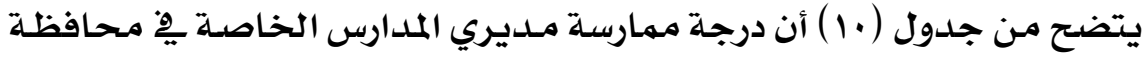

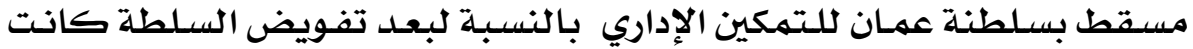

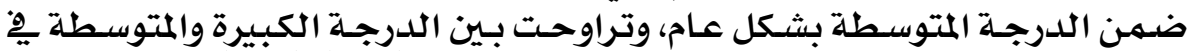

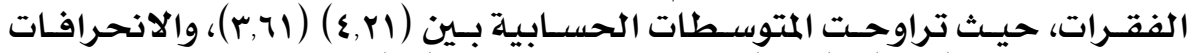

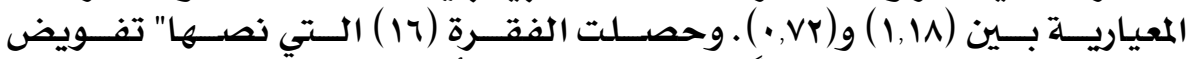

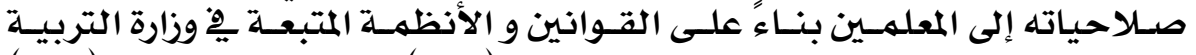

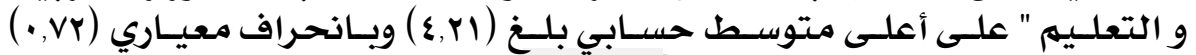




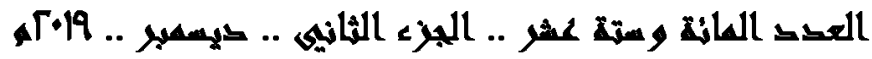

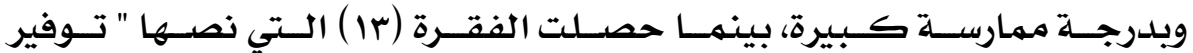

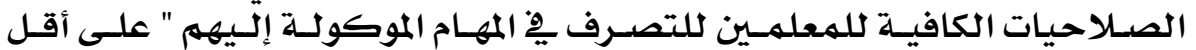

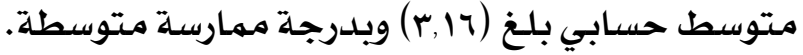

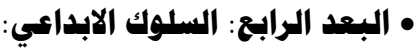

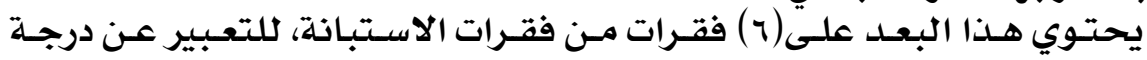

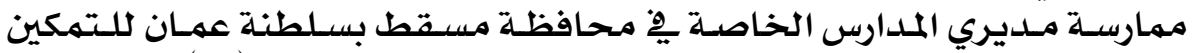

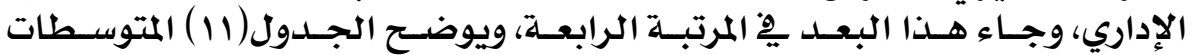

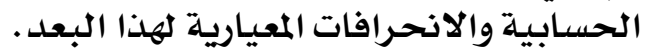

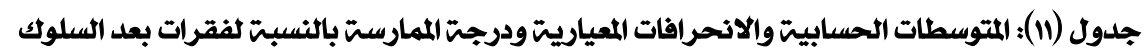
الإبباعي مرتبتَ تنازليا حسب المتوسطات الحسابيت

\begin{tabular}{|c|c|c|c|c|c|}
\hline الدرجة & الالانحراف & الحسابي & الفقرات & $p$ & 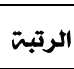 \\
\hline كبيرة & 0.93 & 3.84 & 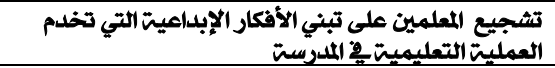 & 23 & $\mathbf{1}$ \\
\hline كبيرة & $\mathbf{0 . 8 7}$ & $\mathbf{3 . 8 3}$ & تشجيع المعلمين على التميز يـ الأداء & 22 & 2 \\
\hline كبيرة & $\mathbf{0 , 8 4}$ & 3.82 & توفير بيئت جيدة لتبنى الأفكار الجديدة بهدف الابداع & 20 & 3 \\
\hline متوسطت & $\mathbf{0 . 8 3}$ & 3.68 & الاهتمام بتجريت الأفكار الجلديدة لدى المعلمين - المدرست & 19 & 4 \\
\hline متوسطة & 0.97 & 3.30 & المدرستمام بالتغيرات الإيجابيتهِ سلوك المعلمين داخل & 21 & 5 \\
\hline متوسطة & 1.25 & 2.87 & تشجيع المعلمين الذين يفكرون خارج نطاق اختصاصهم & 18 & 6 \\
\hline متوسطتة & 0.94 & 3.54 & المحموع الكلي & & \\
\hline
\end{tabular}

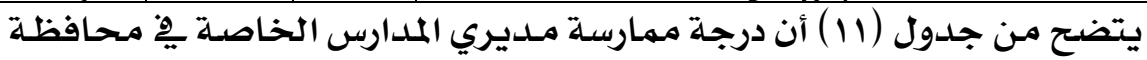

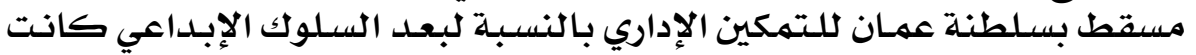



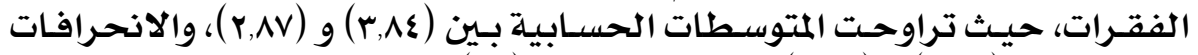

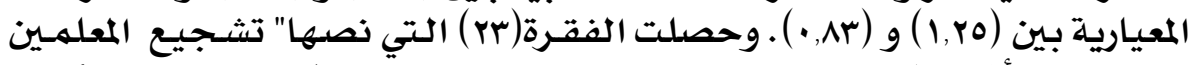

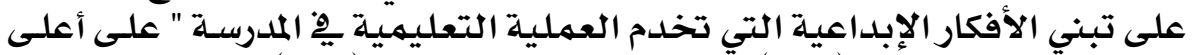

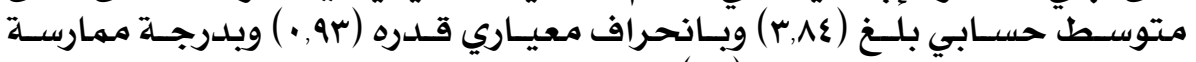

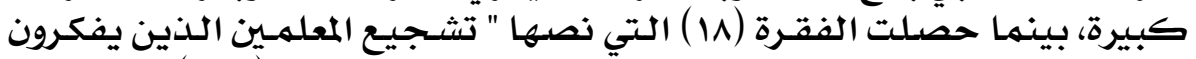

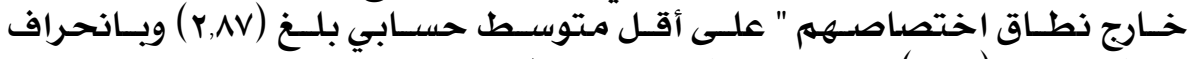

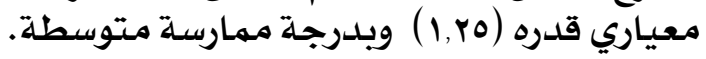

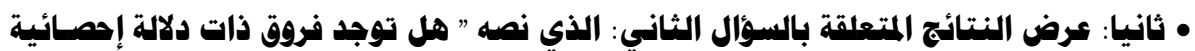

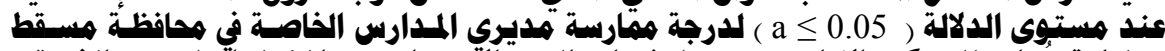

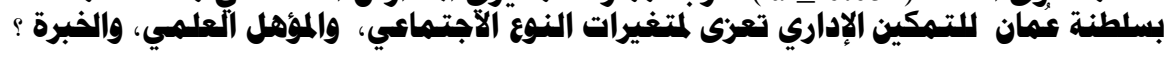

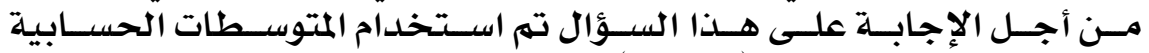

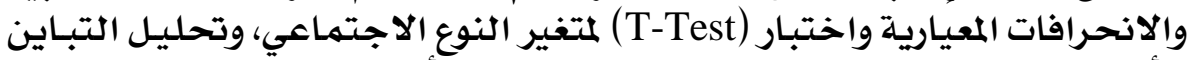

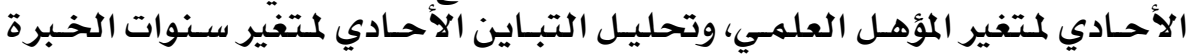

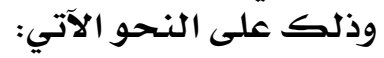

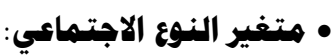

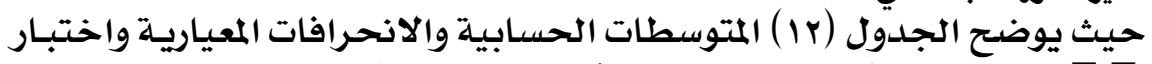
T-Test 


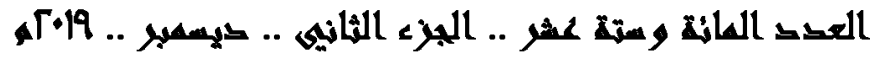
جدول (r) : المتوسطات الحسابيت والانحرافات المعياريت واختبار Test Test لمتغير النوع الاجتمامي لأبعاد

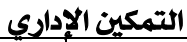

\begin{tabular}{|c|c|c|c|c|c|c|c|}
\hline دلالتة (ت)يات) & مستوى & "تيمت" & الانحريافي & الحسوسطي & العدد & النوع & البعد \\
\hline دالة & 0.01 & -2.23 & 0.93 & 4.29 & 354 & ذكر & المشاركتيْ2 صنع \\
\hline & & & 0.90 & 3.46 & 146 & انثى & القرارات \\
\hline غير دالة & 0.45 & -1.59 & 1.04 & 3.28 & 354 & ذكر & \multirow[t]{2}{*}{ الاستقلاليت_ العمل } \\
\hline & & & 1.00 & 3.49 & 146 & انثي & \\
\hline غير دالتة & 0.27 & 0.35 & 1.01 & 3.53 & 354 & ذكر & \multirow[t]{2}{*}{ تفويض السلطت } \\
\hline & & & 0.94 & 3.51 & 146 & الثي & \\
\hline غير دالتّ & 0.51 & -2.53 & 0.98 & 4.28 & 354 & ذكر & \multirow[t]{2}{*}{ السلوك الابداعي } \\
\hline & & & 0.91 & 4.39 & 146 & انثي & \\
\hline & & & 0.99 & 3.71 & 354 & ذكر & \multirow{2}{*}{ جموع الكلي } \\
\hline الة & 0.31 & 1.67- & 0.93 & 3.66 & 146 & أنثي & \\
\hline
\end{tabular}

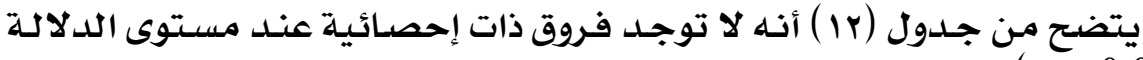

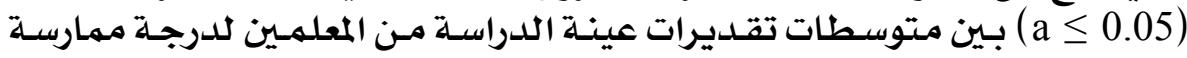

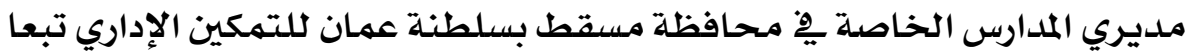

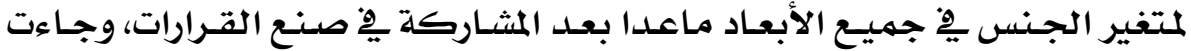
الفروق لصالح الذكور.

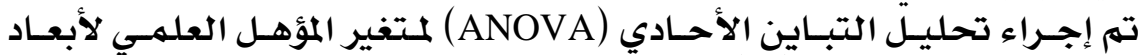

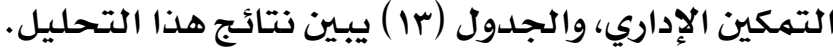
جدول (Ir): نتائج تحليل التباين الأحادي(One way ANOVA) لأبعاد التمكين الإداري تبعاً لمتفير المؤهل العلمي

\begin{tabular}{|c|c|c|c|c|c|c|}
\hline الإحصائيتي & قيمت (ف) & متوسط & الحرجية & مجموع المربعات & مصدر التباين & المحور \\
\hline 0.39 & \multirow[t]{3}{*}{1.00} & 0.59 & 2 & 0.09 & بين المجموعات & \multirow{3}{*}{ المشاركتيّ2 صنّع } \\
\hline \multirow[t]{2}{*}{ فير دالة } & & 0.40 & 497 & 43.07 & داخل المجموعات & \\
\hline & & & 499 & 43.16 & الكلى & \\
\hline 0.76 & \multirow[t]{3}{*}{0.25} & 0.38 & 2 & 0.18 & بين المحموعات & \multirow{3}{*}{ الاستقلاليت ـ2 } \\
\hline \multirow[t]{2}{*}{ فير دالت } & & 0.17 & 497 & 21.37 & داخل المحموعات & \\
\hline & & & 499 & 21.55 & الكلى & \\
\hline 0.69 & \multirow[t]{3}{*}{0.48} & 0.02 & 2 & 0.06 & بين المجموعات & \multirow{3}{*}{ السولطيّ } \\
\hline \multirow[t]{2}{*}{ غير دالت } & & 0.29 & 497 & 49.67 & داخل المجموعات & \\
\hline & & & 499 & 49.73 & الكلى & \\
\hline \multirow{3}{*}{$\begin{array}{l}0.39 \\
0.39 \\
\text { غير دالة }\end{array}$} & \multirow[t]{3}{*}{1.22} & 0.44 & 2 & 0.83 & بين المجموعات & \multirow{3}{*}{ الابلداعي } \\
\hline & & 0.18 & 497 & 29.71 & داخل المجموعات & \\
\hline & & & 499 & 30.54 & الكلى & \\
\hline
\end{tabular}

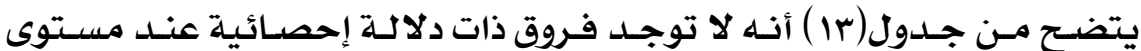

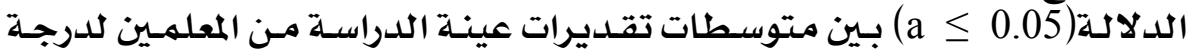

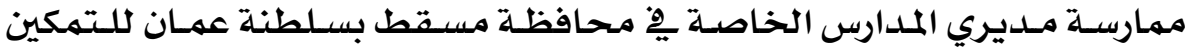

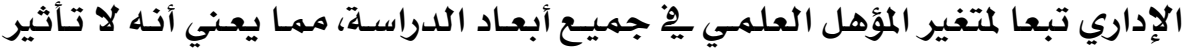

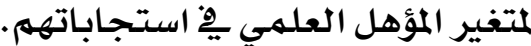

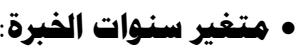

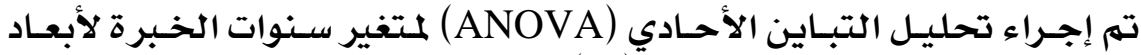
التمكين الإداري حيث يوضيث التبـاين الجدول (عادي (1) نتائج هذا التحليل. 




جلول (ع) ): نتائج تحليل التباين الأحادي) متغير سنوات الخبرة لأبعاد التمكين الإداري

\begin{tabular}{|c|c|c|c|c|c|c|}
\hline الإحصائيتي & قيمت (ف) & متوسط المربعات & الحرجيت & مجموع المربعات & مصدر التباين & المحود \\
\hline 0.64 & \multirow[t]{3}{*}{0.49} & 0.09 & 2 & 0.16 & بين المجموعات & \multirow{3}{*}{ المنع القراراتِ } \\
\hline \multirow[t]{2}{*}{ فير دالتة } & & 0.18 & 497 & 33.61 & داخل المجموعات & \\
\hline & & & 499 & 33.77 & الكلى & \\
\hline 0.32 & \multirow[t]{3}{*}{1.03} & 0.14 & 2 & 0.48 & بين المجموعات & \multirow{3}{*}{ 'الاستقلاليتة } \\
\hline \multirow{2}{*}{ فير دالت } & & 0.21 & 497 & 39.80 & داخل المجموعات & \\
\hline & & & 499 & 40.28 & الكلى & \\
\hline 0.71 & \multirow[t]{3}{*}{0.26} & 0.05 & 2 & 0.09 & بين المجموعات & \multirow{3}{*}{ تفويضت } \\
\hline \multirow[t]{2}{*}{ فير دالت } & & 0.20 & 497 & 40.11 & داخل المجموعات & \\
\hline & & & 499 & 40.20 & الكلى & \\
\hline 0.65 & \multirow[t]{3}{*}{0.47} & 0.41 & 2 & 0.85 & بين المجموعات & \multirow{3}{*}{ الابلواعي } \\
\hline \multirow[t]{2}{*}{ غير دالتة } & & 0.18 & 497 & 41.73 & داخل المجموعات & \\
\hline & & & 499 & 42.58 & الكلى & \\
\hline
\end{tabular}

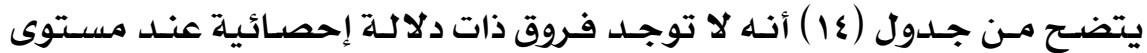

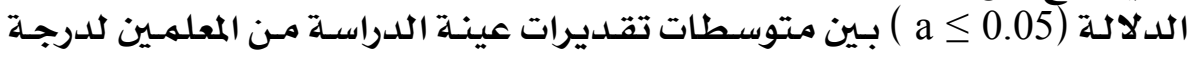

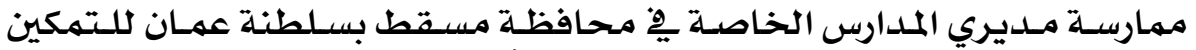

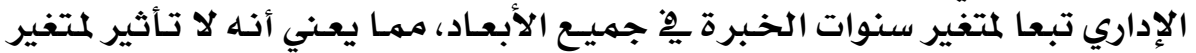

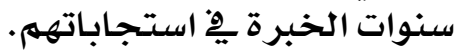

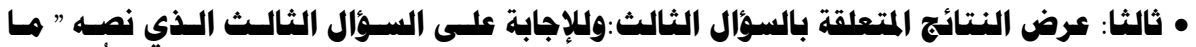

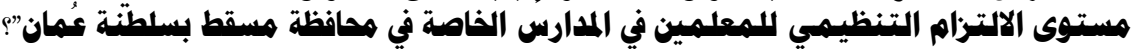

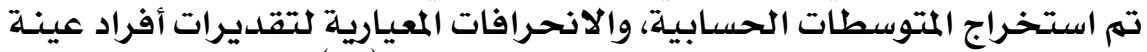

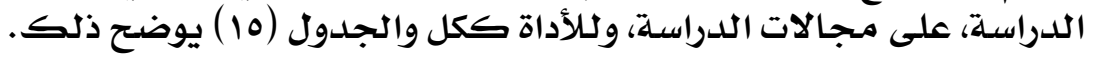
جلدول (10): المتوسطات الحسابيت والانحرافات المعياريت لمجالات مستوى الالتزام التنظيمي لمعلمي المدارس

\begin{tabular}{|c|c|c|c|c|c|}
\hline \multicolumn{6}{|c|}{ الخاصت } \\
\hline الدرجت & الالانحراف & الحسوسطي & المجال & الترتيب & $p$ \\
\hline متوسطت & 1.00 & 3.54 & الالتزام بالمسؤوليت تحاه المدرست & 2 & 1 \\
\hline كييرة & $\mathbf{1 . 0 3}$ & 3.88 & الالتزام العاطفى & 1 & 2 \\
\hline متوسطت & $\mathbf{0 . 7 7}$ & 3.40 & الالتزام المستمر & 3 & 3 \\
\hline متوسطت & 0.93 & 3.60 & لستوى الكلب & & \\
\hline
\end{tabular}

يتضح من جدول (10) أن مستوى الالتزام التتظيهـي لمعلهـي المدارس الخـاصسة

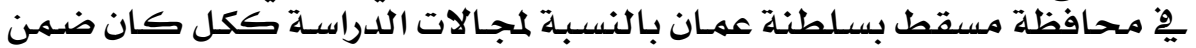

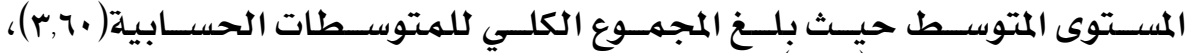

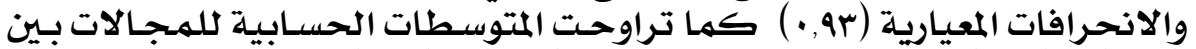

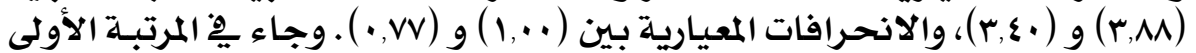

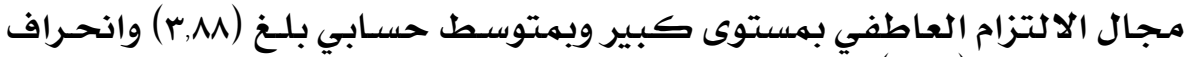

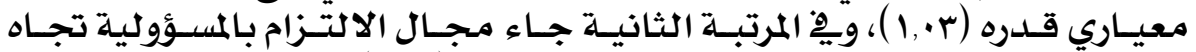

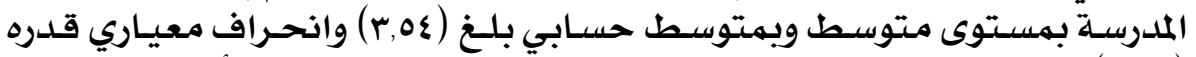

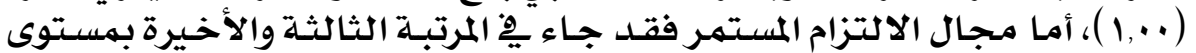
متوسط ومتتوسط حسابي بلغ ( • ع.ب) وانحراف معياري قدره (VV, • ) . 


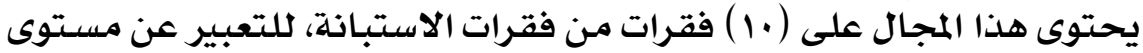

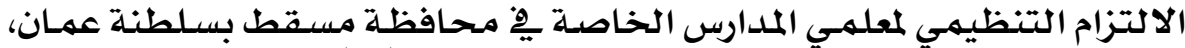

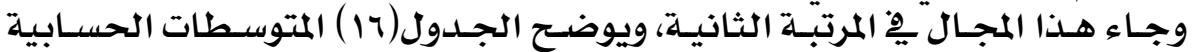

$$
\text { والانحرافات المعيارية لهذا المجات المجال. }
$$

جدول (17): المتوسطات الحسابيت والانحرافات المعياريت ومستوى الالتزام التنظيمي بالنسبت لفقرات

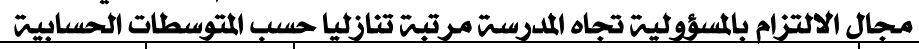

\begin{tabular}{|c|c|c|c|c|c|}
\hline الدرجت & الالانحراف & الحسوابط & 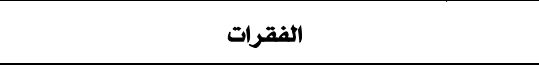 & $p$ & الرتبتة \\
\hline كبيرة & 0.80 & 4.08 & 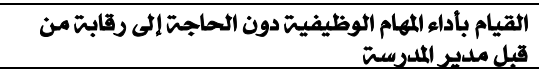 & $\mathbf{1}$ & 1 \\
\hline كبيرة & $\mathbf{0 . 9 7}$ & 3.76 & الاهتمام بسمعت ومستقبل المدرست & 3 & 2 \\
\hline كبيرة & 0.91 & 3.73 & الشعور بالواجب اتجاه نجاح المدرست واستمر & 5 & 3 \\
\hline متوسطتة & $\mathbf{1 . 0 3}$ & 3.67 & بذل جهدا كبيرا لتحقيق أهداف المدرستة & 2 & 4 \\
\hline متوسطنة & $\mathbf{1 . 0 0}$ & 3.56 & الشعور بان المدرستّ تستحق الالتزام والإخلاص ه العمل & 10 & 5 \\
\hline متوسطنة & 1.00 & 3.44 & الاهتمام بالحصول على المعلومات ذات الفائدة للمدرست & 7 & 6 \\
\hline متوسطتي & $\mathbf{0 . 8 9}$ & 3.34 & الاهتمام كثيرا بتفوق الطلبتــ المدرست & 9 & 7 \\
\hline متوسطتة & 1.00 & 3.32 & الحرص على تطبيق اللوائح والقوانين الخاصت بالمدرست & 4 & 8 \\
\hline متوسطتة & 1.16 & 3.31 & ممتلكات شخصلى الممتلكات الخاصتّ بالمدرست وكاثها & 8 & 9 \\
\hline متوسطنة & 1.32 & 3.18 & المحافظت على العمل وإنجازه & 6 & 10 \\
\hline متوسطنة & 1.00 & 3.54 & المجموع الكلى & & \\
\hline
\end{tabular}

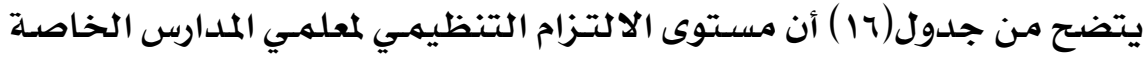

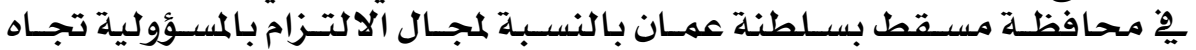

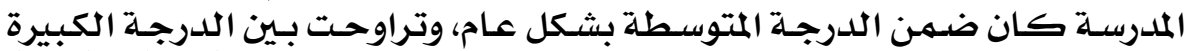

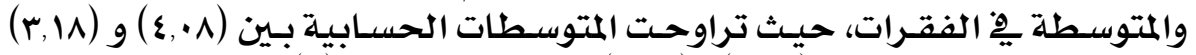

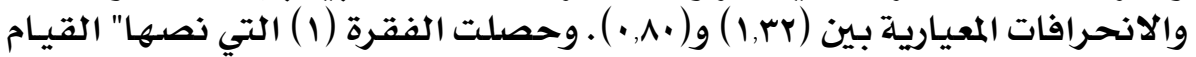

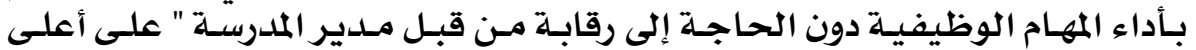

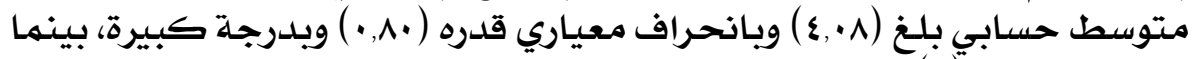

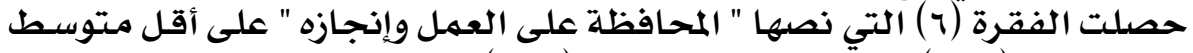

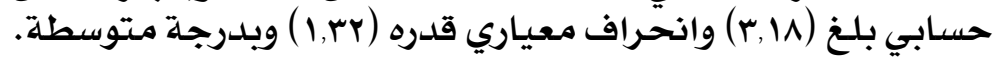

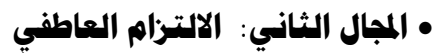

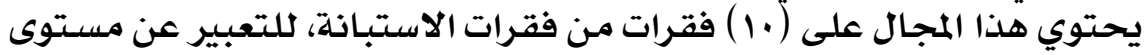



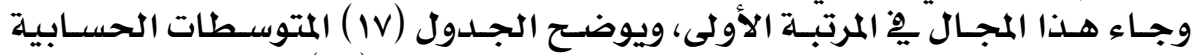

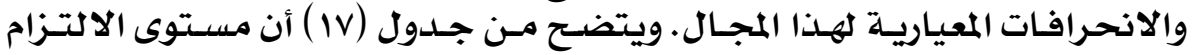

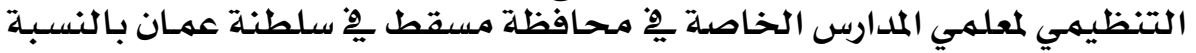

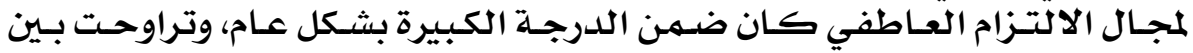

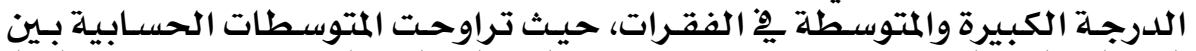

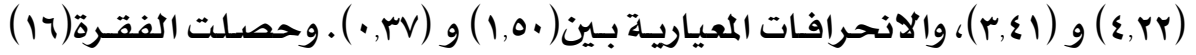




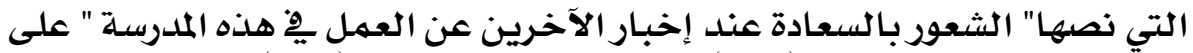

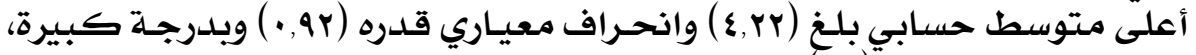

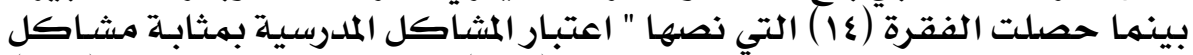

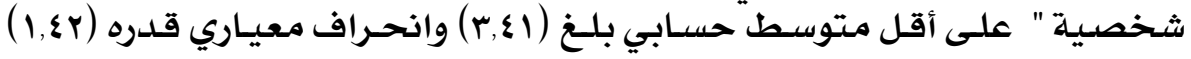
وبلدرجة منتوسطة.

جلدول (IV): المتوسطات الحسابيت والانحرافات المعياريت ومستوى الالتزام التنظيمي بالنسبت لفقرات

\begin{tabular}{|c|c|c|c|c|c|}
\hline الدرجت & الانحراف & الحستوسط & الفقرة & $p$ & الرتبة - الر \\
\hline كبيرة & 0.92 & 4.22 & هذه المدور بالسعادة عند إخبار الآخرين عن العمل فㅇ & 16 & 1 \\
\hline كبيرة & $\mathbf{0 . 7 7}$ & 4.13 & الاتفاق بين قيم المعلم وقيم المدرست & 15 & 2 \\
\hline كبيرة & 0.87 & 4.12 & يوجد ارتباط عاطفى بين المعلم والمدرست & 11 & 3 \\
\hline كبيرة & 0.93 & 4.11 & التوافق بين الأهداف الشخصيت واهداف المدرست & 13 & 4 \\
\hline كبيرة & 1.34 & 4.00 & الشعور بدرجت عاليت من الالتزام تجاه العمل & 19 & 5 \\
\hline كبيرة & 0.37 & 3.95 & الشعور بالسعادة للعمل مِ هذه المدرستي & 12 & 6 \\
\hline كبيرة & 1.24 & 3.68 & الثقت بالمدير والمعلمين بدرجت كبيرة & 20 & 7 \\
\hline متوسطت & 0.97 & 3.66 & الارتباط بالعمل بدوافع ذاتيت & 18 & 8 \\
\hline متوسطن & $\mathbf{1 . 5 0}$ & 3.52 & قضاء أوقات ممتعت مِ المدرستة & 17 & 9 \\
\hline متوسطت & 1.42 & 3.41 & امتبار المشاكل المدرسيت بمثابت مشاكل شخصيت & 14 & 10 \\
\hline كبيرة & $\mathbf{0 . 7 7}$ & 3.88 & المجموع الكلى & & \\
\hline
\end{tabular}

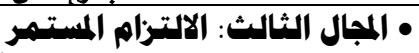

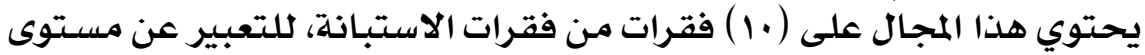

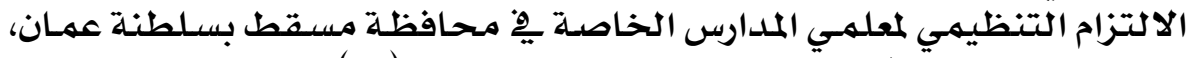

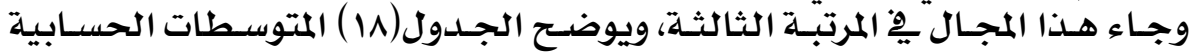

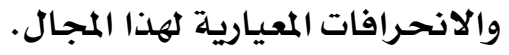

جلدول (U): المتوسطات الحسابيت والانحرافات المعياريت ومستوى الالتزام التنظيمي بالنسبت لفقرات

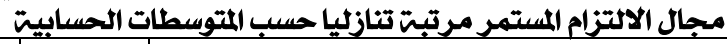

\begin{tabular}{|c|c|c|c|c|c|}
\hline الدرجة & الالانحياري & الحسابى & 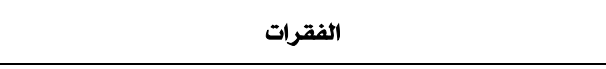 & الرقم & الرتبت \\
\hline كبيرة & $\mathbf{0 . 5 8}$ & 4.00 & العمل بصورة مستمرة على تذليل الصعويات التى تواجه المدرستة & 22 & 1 \\
\hline كبيرة & 0.62 & 3.88 & الافتخار باستمرار العلاقات مع زملاء العمل & 30 & 2 \\
\hline كبيرة & 0.49 & 3.77 & التطلع للحصول على ترقيه وظيفيت ــ المدرست & 27 & 3 \\
\hline كبيرة & 0.43 & 3.71 & الرغبتش يـ الاستمرار بالعمل يـ المدرستشحتى التقاعد & 21 & 4 \\
\hline متوسطنة & 1.13 & 3.65 & تقبل أي مهمت يكلف بها مقابل الاستمرار ــ المدرست & 25 & 5 \\
\hline متوسطنة & 0.61 & 3.51 & الرغبت يخ البقاء يف العمل مهما توفرت فرص بديلتي & 23 & 6 \\
\hline متوسطنة & 0.96 & 3.35 & الاستعداد لبذل مزيلِ من الجهد للمساهمت فِ نجلح المدرست & 29 & 7 \\
\hline متوسطت & 0.97 & 3.02 & السعى للمشاركت ـ إلجان التى تقدم خدمت لصالح المدرستة & 24 & 8 \\
\hline متوسطنة & 0.98 & 2.82 & اعتبار الوجود على رأس العمل استثمارا وظيفياجيدا & 28 & 9 \\
\hline متوسطت & .96 & 2.35 & الشعور بالحصول على مكاسب كثيرة عند الانتماء لهذه المدرست & 26 & 10 \\
\hline متوسطتة & 0.77 & 3.40 & المجموع الكلى & & \\
\hline
\end{tabular}

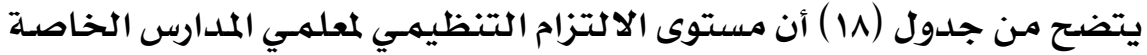

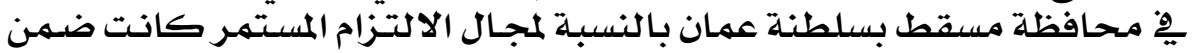

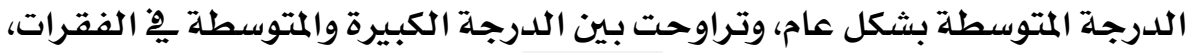




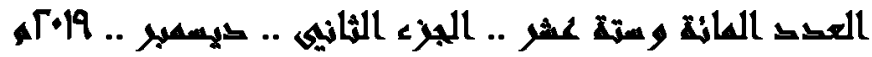

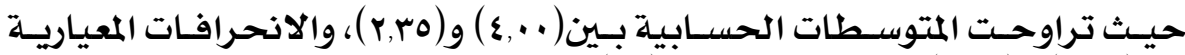

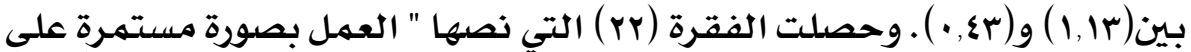

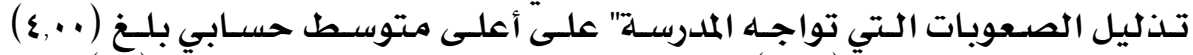

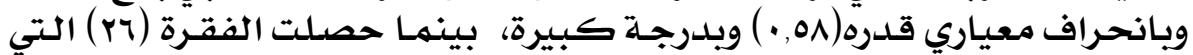

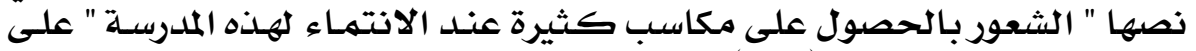

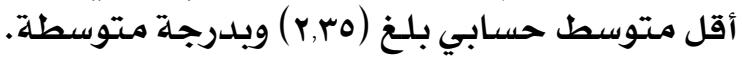

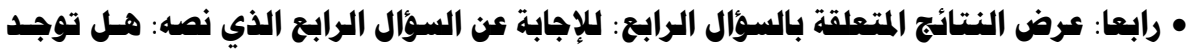

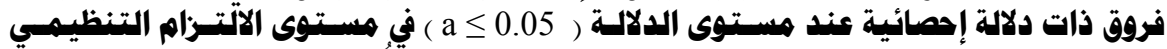

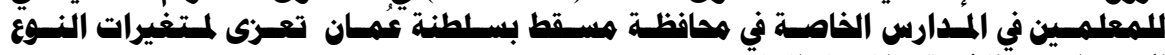

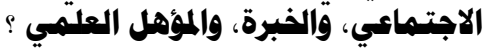

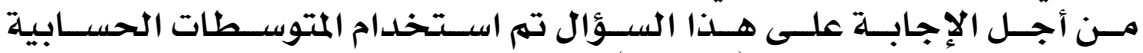

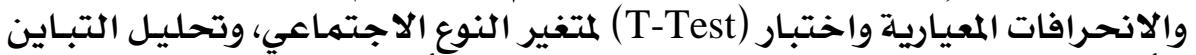

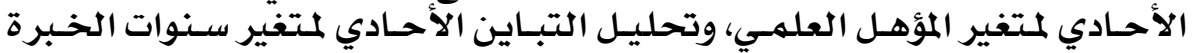
وذلك على النحو الآتي:

\section{1-هتغير النوع الاجتهاعي:}

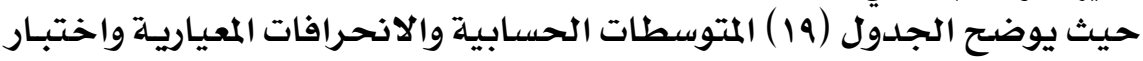
T-Test

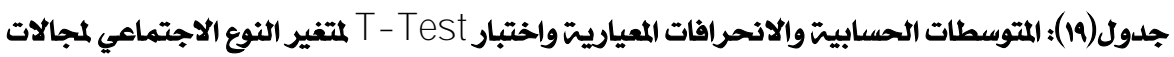

\begin{tabular}{|c|c|c|c|c|c|c|c|}
\hline \multicolumn{8}{|c|}{ الاتتزام التنظيمي } \\
\hline دلالتشئيا & مستوى & "تيمت & الالعياري & الحسوسط & العدد & النوع & 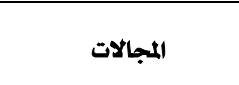 \\
\hline فير دالة & 0.83 & 0.41 & 0.84 & 4.14 & 354 & ذكر & الالتزام بالكسؤوليت تجاه \\
\hline & & & 0.88 & 4.20 & 146 & انثى & المدرستة \\
\hline غير دالتة & 0.71 & -1.44 & 0.92 & 3.90 & 354 & ذكر | ( ل & الالتزام العاطفي \\
\hline & & & 0.98 & 3.89 & 146 & اثثى & \\
\hline غير دالت & 0.60 & 0.02 & 0.78 & 4.11 & 354 & ذكر & 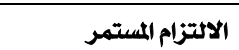 \\
\hline & & & 0.81 & 4.07 & 146 & 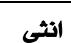 & \\
\hline & & & 0.84 & 4.05 & 354 & ذكر & المجموع الكلى الملى المجل \\
\hline غير دالة & 0.70 & -0.33 & 0.89 & 4.03 & 146 & أنثى & \\
\hline
\end{tabular}

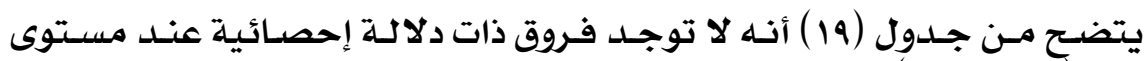

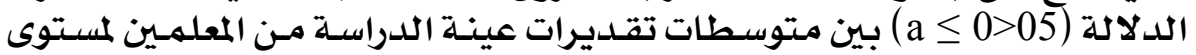

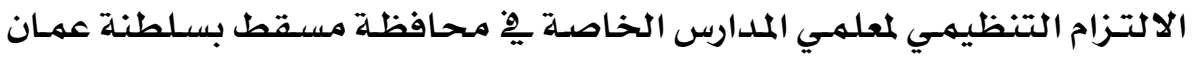

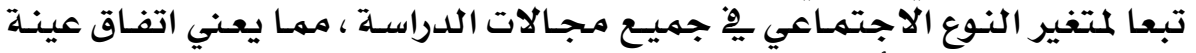

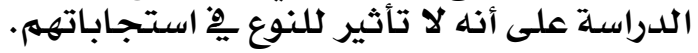

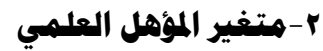

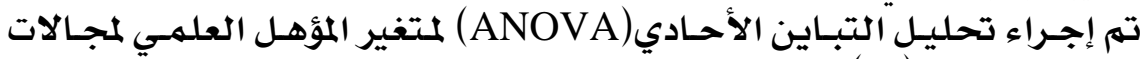

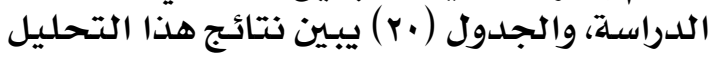




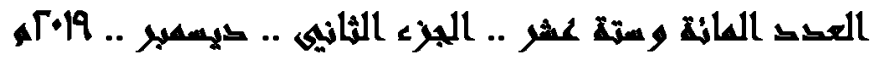

\begin{tabular}{|c|c|c|c|c|c|c|}
\hline الإحصائيت & قيمة (ف) & متوسط المربعات & درجات & مجموع المربعات & مصدر التباين & المجالات \\
\hline 0.21 & \multirow[t]{3}{*}{0.45} & 0.37 & 2 & 0.74 & بين المجموعات & \multirow{3}{*}{ بالالاؤزوليتيت } \\
\hline \multirow[t]{2}{*}{ فير دالتة } & & 0.72 & 497 & 31.42 & داخل المجموعات & \\
\hline & & & 499 & 32.16 & الكلى & \\
\hline 0.48 & \multirow[t]{3}{*}{0.35} & 0.04 & 2 & 0.51 & بين المجموعات & \multirow{3}{*}{ الالتزام } \\
\hline \multirow{2}{*}{ فير دالة } & & 0.29 & 497 & 22.64 & داخل المجموعات & \\
\hline & & & 499 & 23.15 & الكلى & \\
\hline 0.62 & \multirow[t]{3}{*}{0.87} & 0.53 & 2 & 1.21 & بين المجموعات & \multirow[t]{3}{*}{ الالتزام المستمر } \\
\hline \multirow[t]{2}{*}{ غير دالت } & & 0.17 & 497 & 29.43 & داخل المجموعات & \\
\hline & & & 499 & 30.64 & الكلى & \\
\hline
\end{tabular}

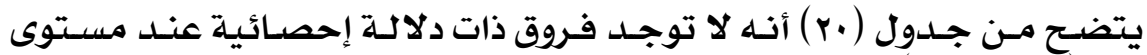

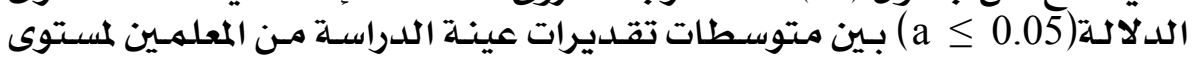

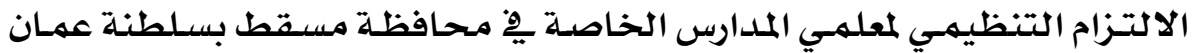

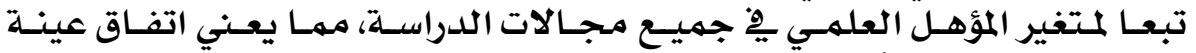

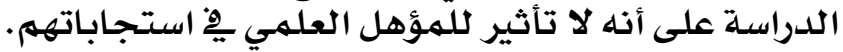

r-متفير سنوات الخبرة:

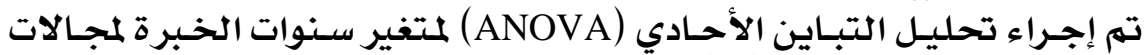

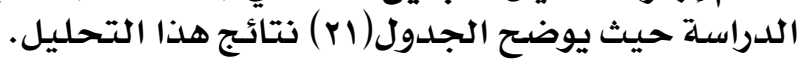

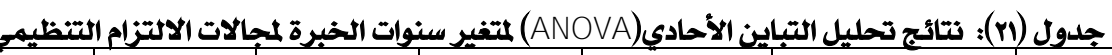

\begin{tabular}{|c|c|c|c|c|c|c|}
\hline الإحصائية & قيمت (ف) & متوسط المربعات & درجات الحريتة & مجموق المربعات & مصدر التباين & المجال \\
\hline \multirow{3}{*}{$\begin{array}{c}0.36 \\
\text { فير دالن }\end{array}$} & 1.04 & 0.32 & 2 & 0.62 & بين المجموعات & \multirow{3}{*}{ لجالألمؤوليتيت } \\
\hline & & 0.37 & 497 & 33.51 & داخل المجموعات & \\
\hline & & & 499 & 34.13 & الكلى & \\
\hline \multirow{3}{*}{$\begin{array}{c}0.82 \\
\text { غير دالتّ }\end{array}$} & 0.31 & 0.18 & 2 & 0.27 & بين المجموعات & \multirow{3}{*}{ العاطفزي } \\
\hline & & 0.66 & 497 & 65.41 & داخل المجموعات & \\
\hline & & & 499 & 65.68 & الكلى & \\
\hline \multirow{2}{*}{$\begin{array}{c}0.37 \\
\text { غير دالة }\end{array}$} & 0.26 & 0.05 & 2 & 0.09 & بين المجموعات & \multirow{2}{*}{ |الالالتزام } \\
\hline & & 0.19 & $\begin{array}{l}497 \\
99\end{array}$ & $\frac{34.76}{3485}$ & داخل المجموعات & \\
\hline
\end{tabular}

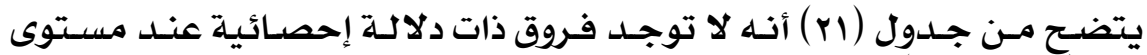

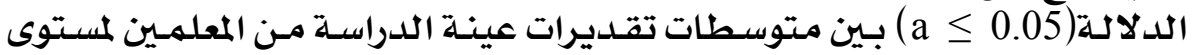

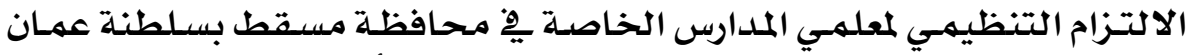

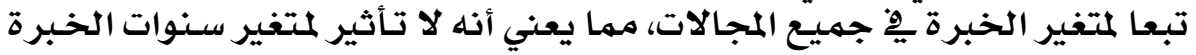

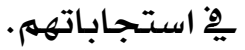

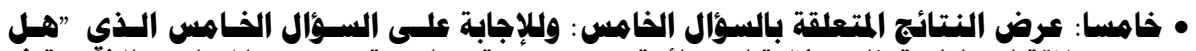

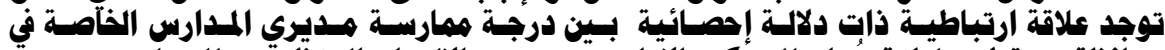

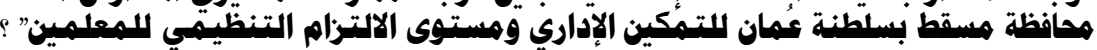

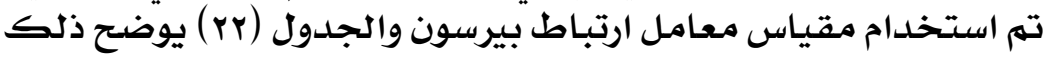

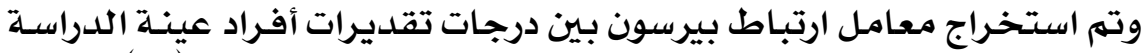

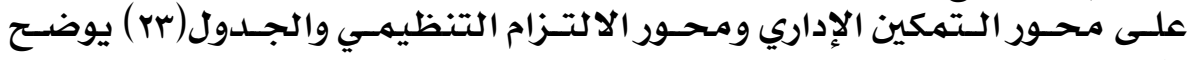
ذلك: 


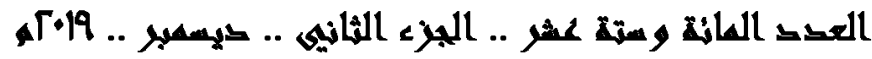

جلول(rr): مقياس معامل ارتباط بيرسون

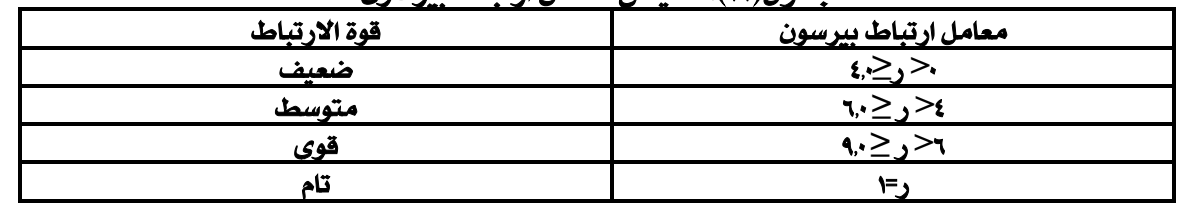

\begin{tabular}{|c|c|c|c|}
\hline \multicolumn{4}{|c|}{ جدول (rr): العلاقت الارتباطيت بين التمكين الإداري والالتزام التتظيمي } \\
\hline آلآلتزام المستمر & الالتزام العاطفي & الالتزام بالمسؤوليتَ اتجاه & مستوى الالتزام التتظيمي الإدي \\
\hline $0.651 * *$ & $0.551 * *$ & $0.663^{* * *}$ & المشاركت 2 صنع القرارات \\
\hline $0.622 * *$ & $0.591 * *$ & $0.544 * *$ & الاستقلاليت 2 العمل \\
\hline $\mathbf{0 . 5 8 0} * *$ & $0.441 * *$ & $0.493 * *$ & تفويض السلطة \\
\hline $0.491 * *$ & $0.523 * *$ & $0.463 * *$ & السلوك الإبداعي \\
\hline $0.550 * *$ & & ياط للمحموع الكلى دئ الا & \\
\hline
\end{tabular}

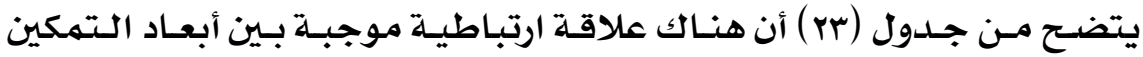

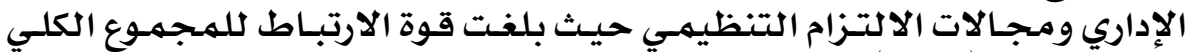

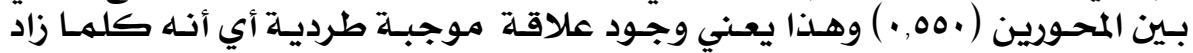

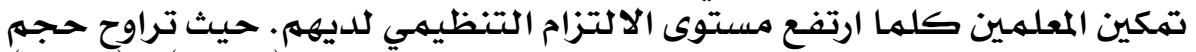

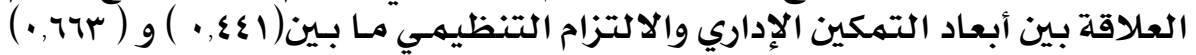

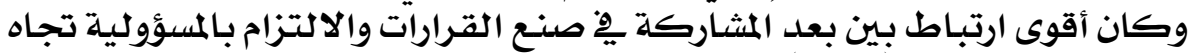

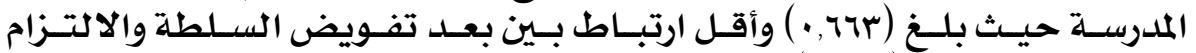

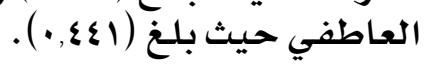

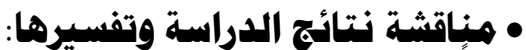

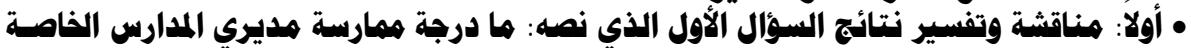

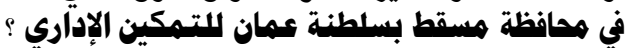

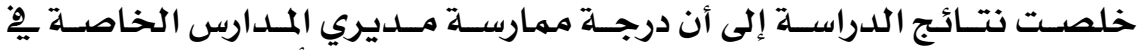

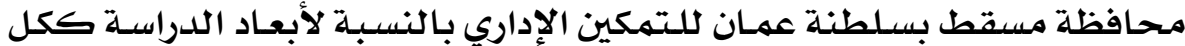

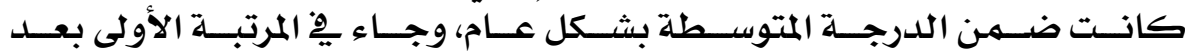

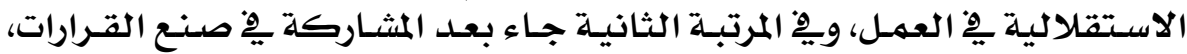

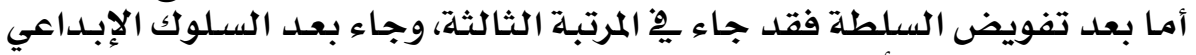

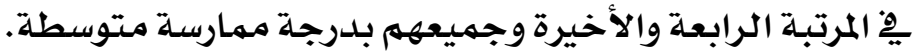

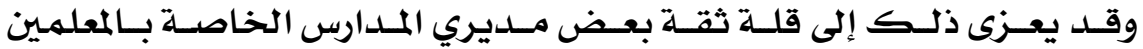

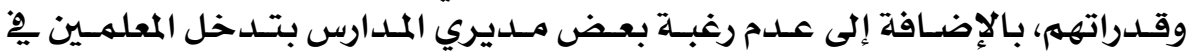

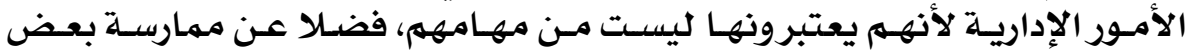

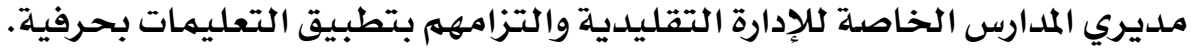

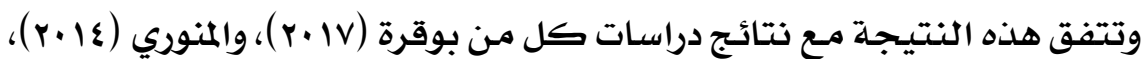

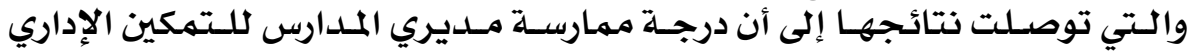

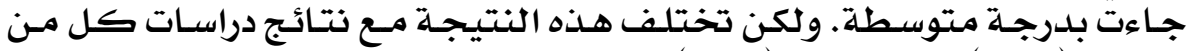

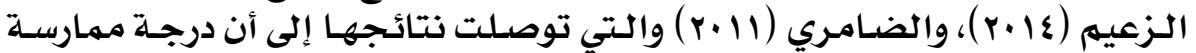

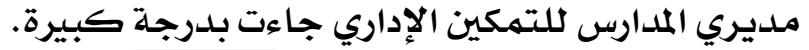




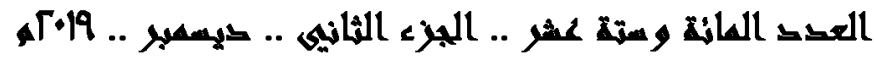

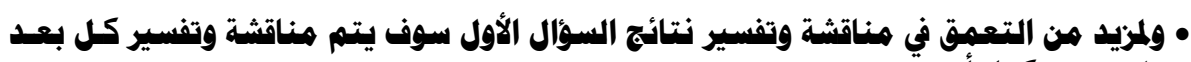

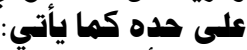

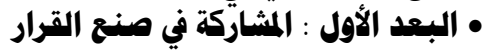

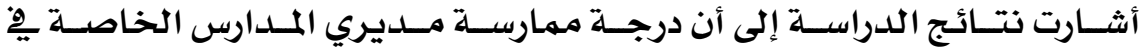

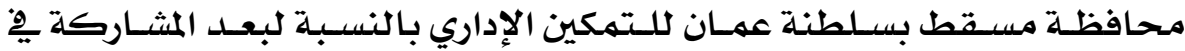

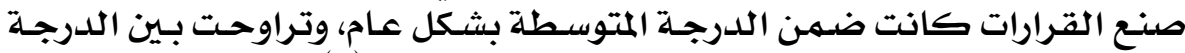

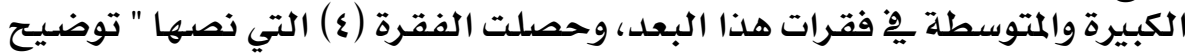

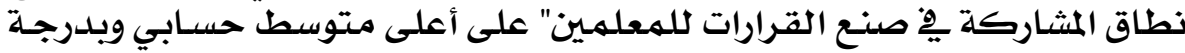

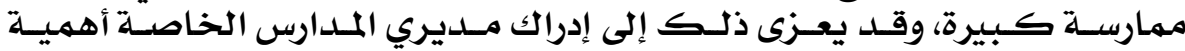

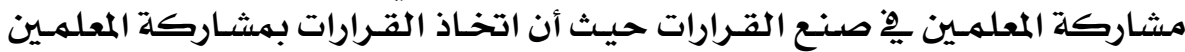

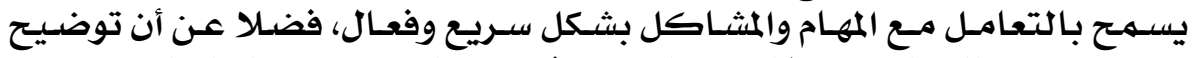

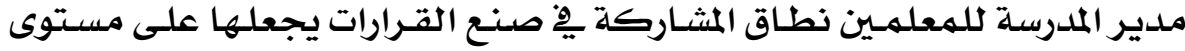
عال من الجودة والفعالية.

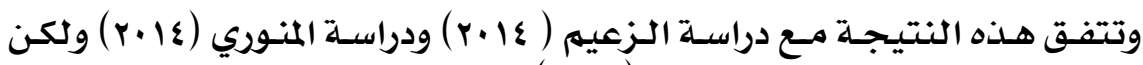

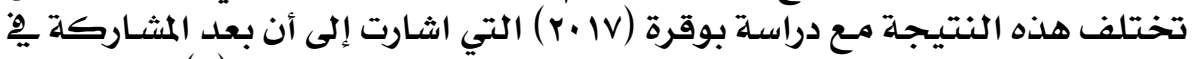

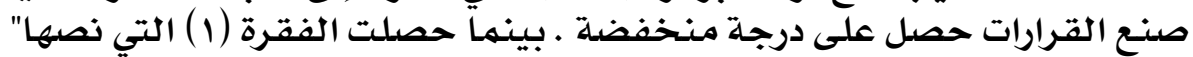

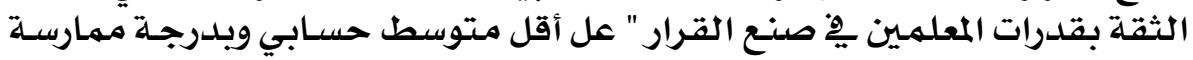

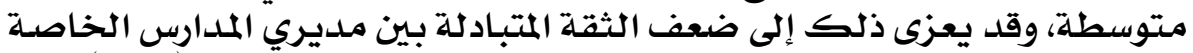

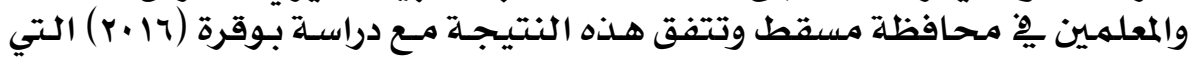

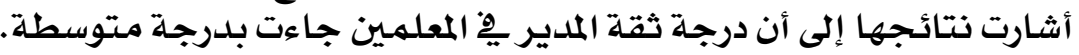

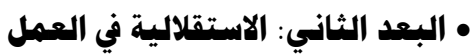

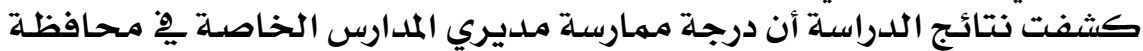

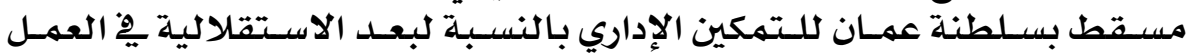

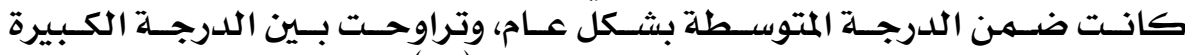

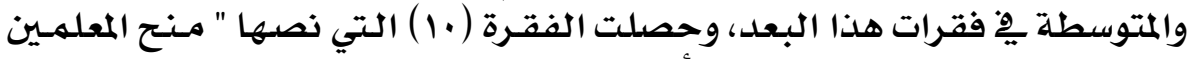

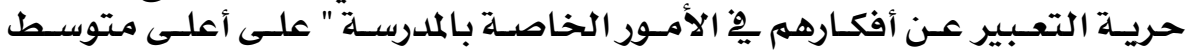

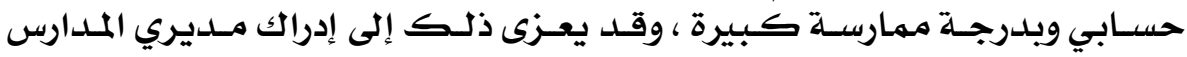

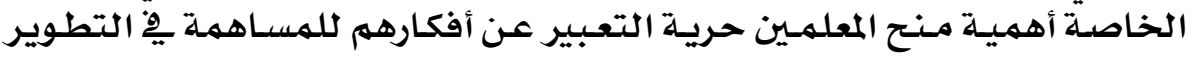

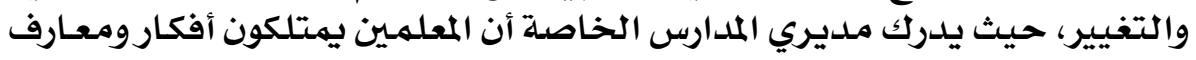

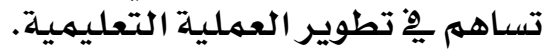

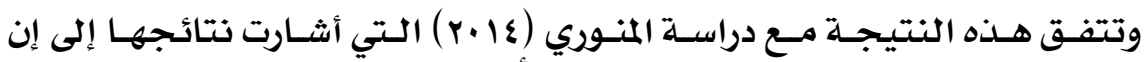

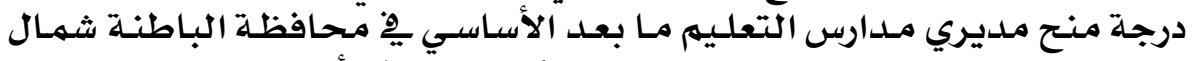

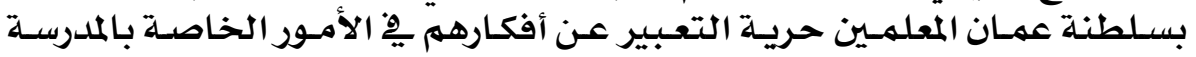
جاءت بلدرجة كبيرة.

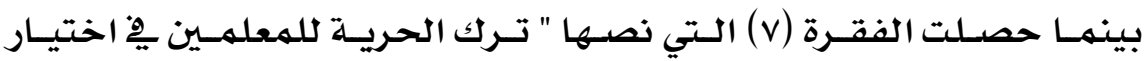

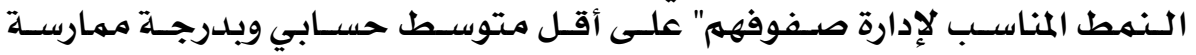




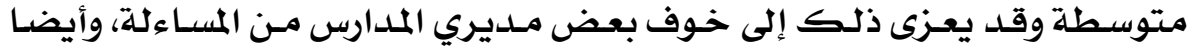

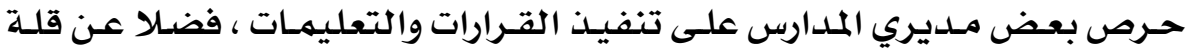

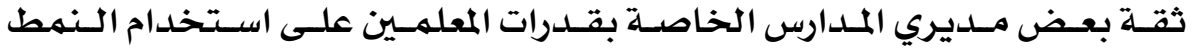

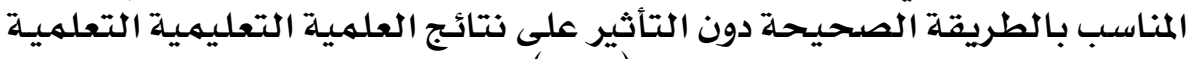

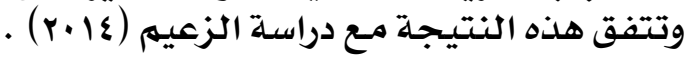

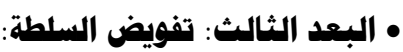

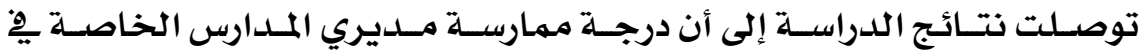

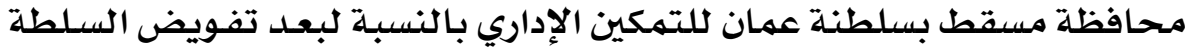

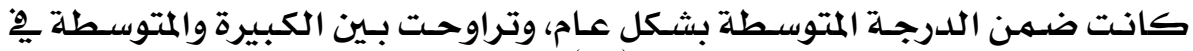

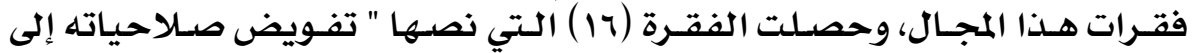

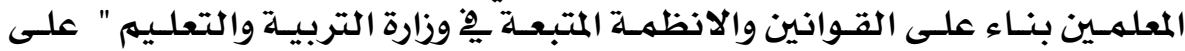

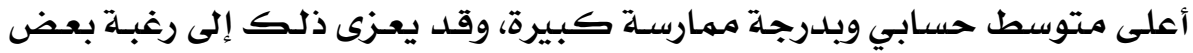

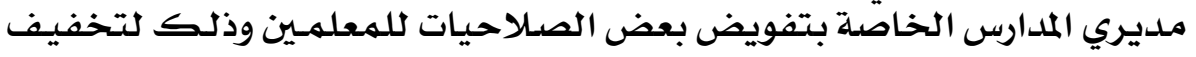

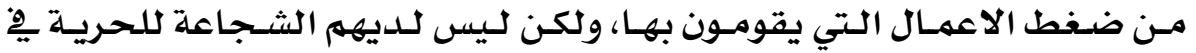

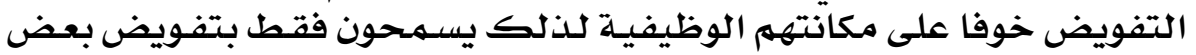

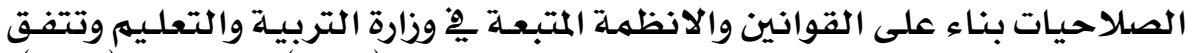

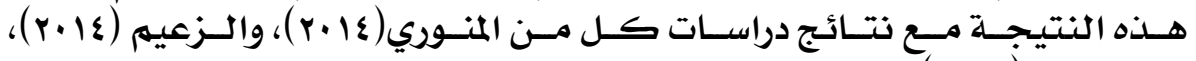

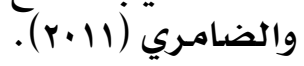

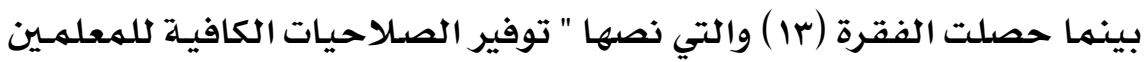

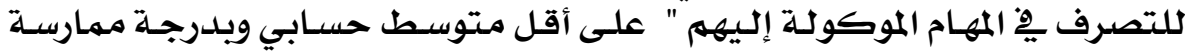

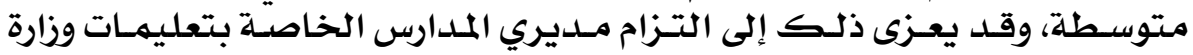

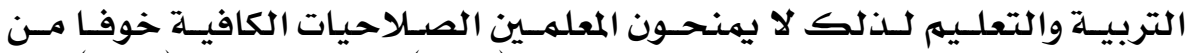

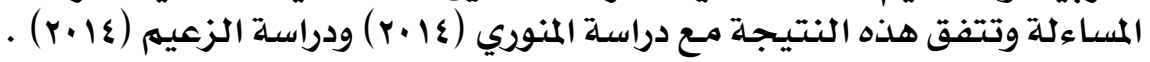

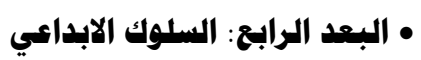

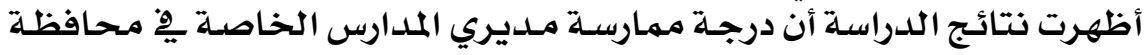

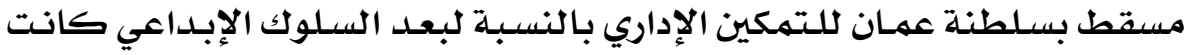

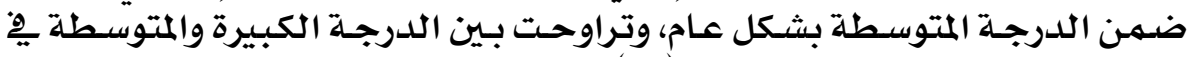

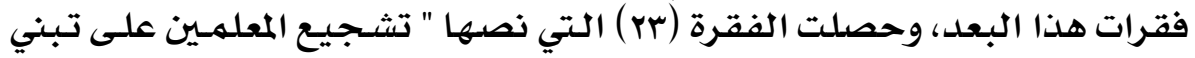

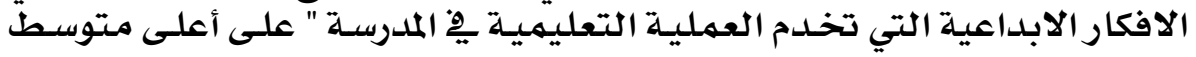

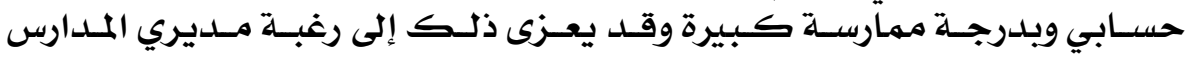

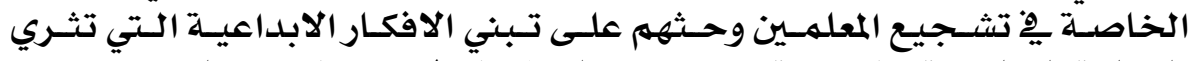

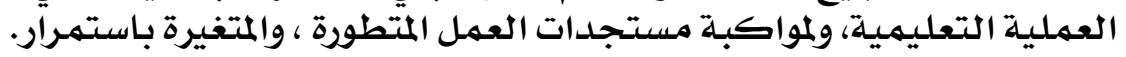

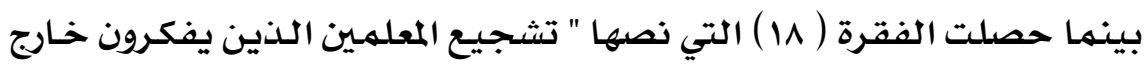

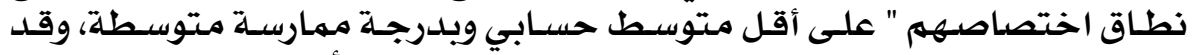

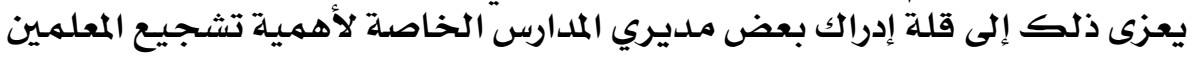

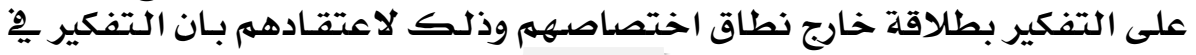




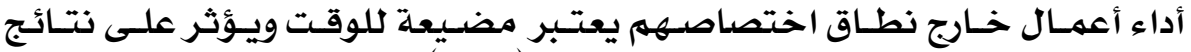

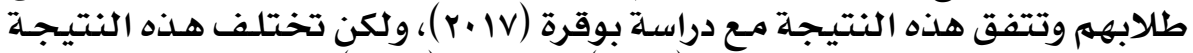

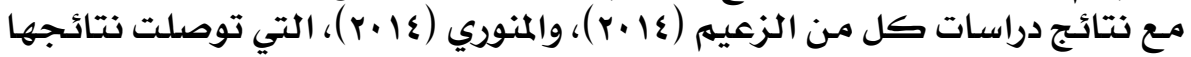

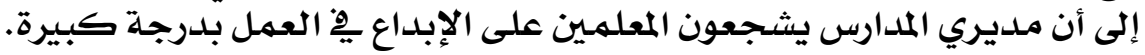

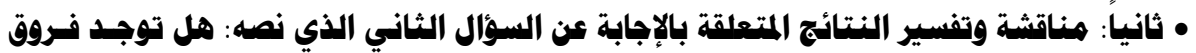

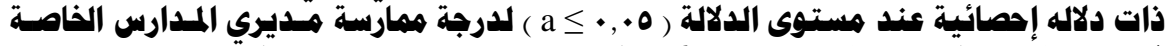

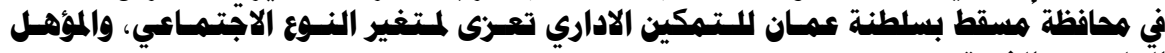

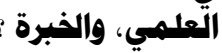

وسوف يتهم مناقشة وتفسير نتائج كل متغير على حده على النحو الآتي:

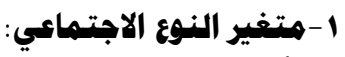

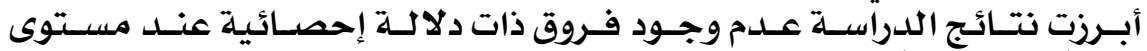

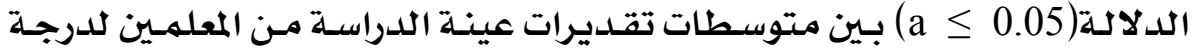

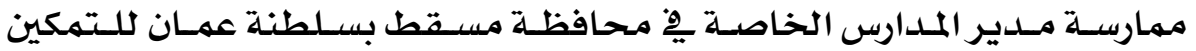

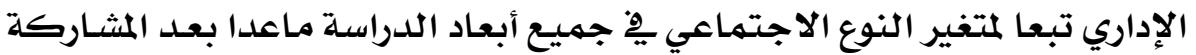

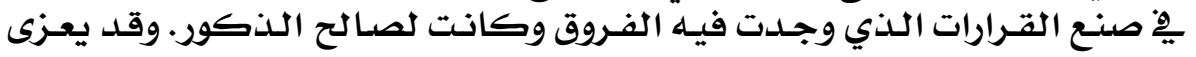

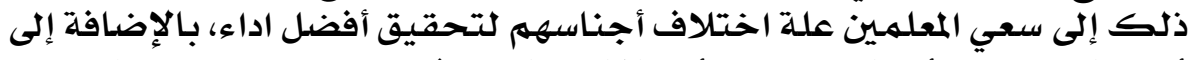

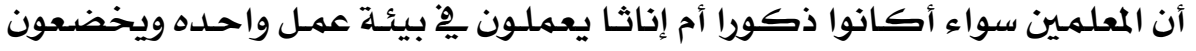

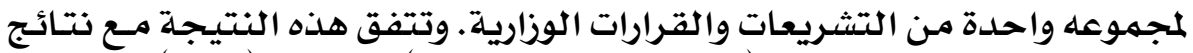

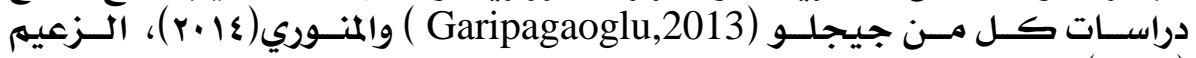

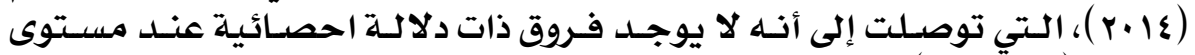

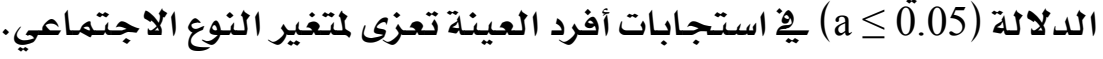

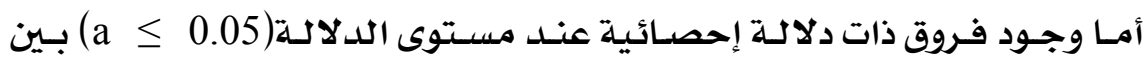

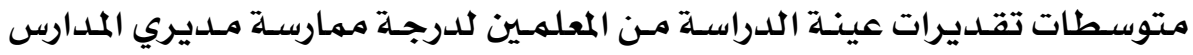

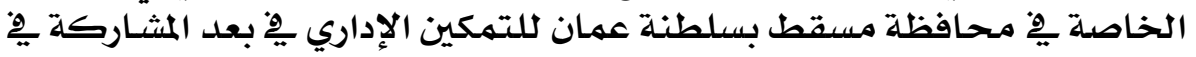

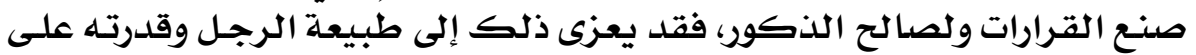

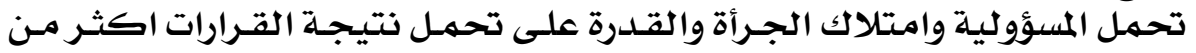

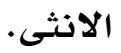

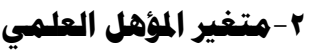

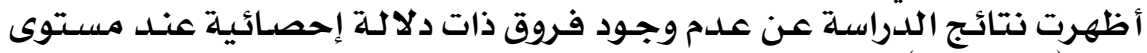

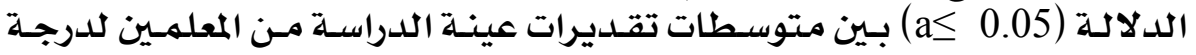

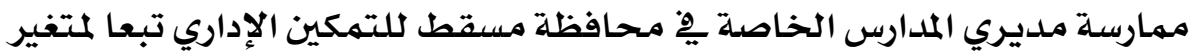

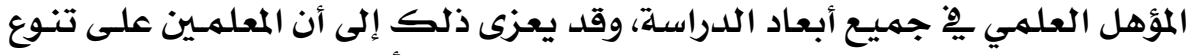

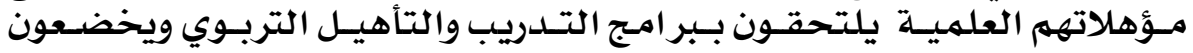

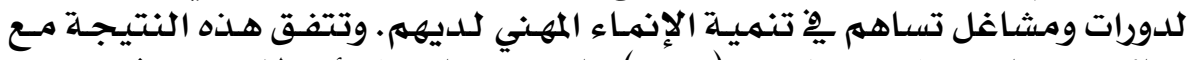

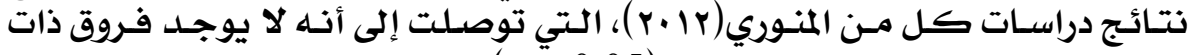

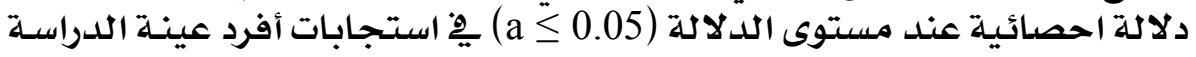




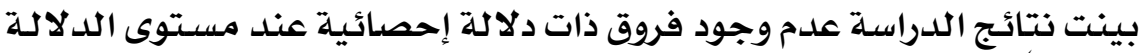

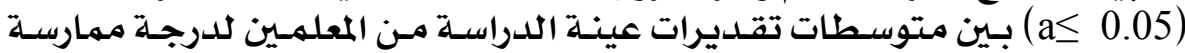

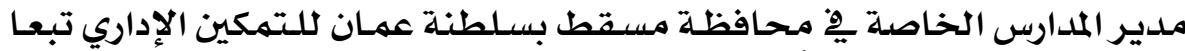

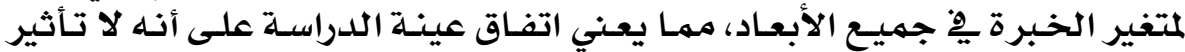

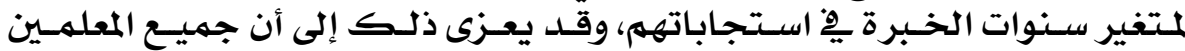

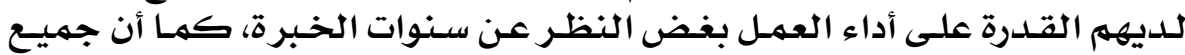

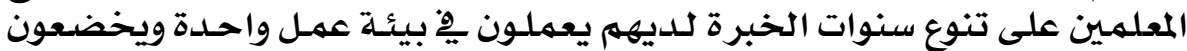

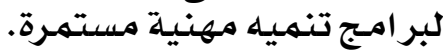

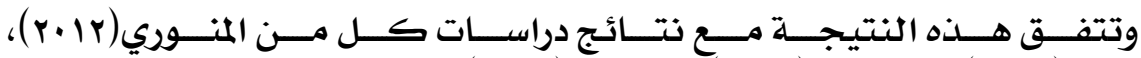

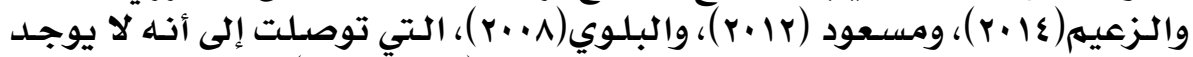

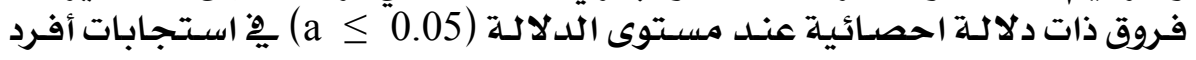

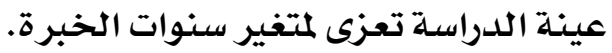

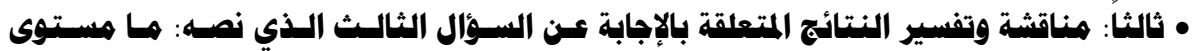

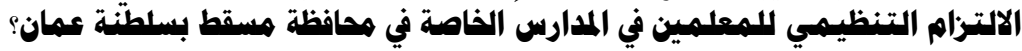

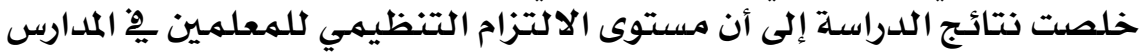

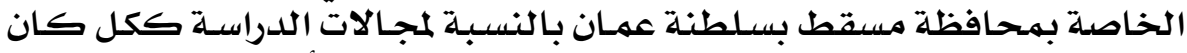

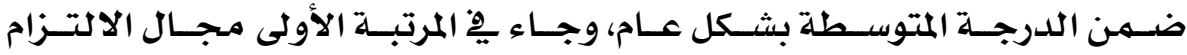

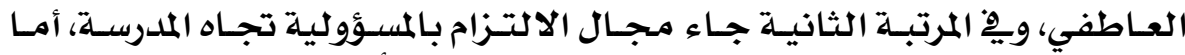

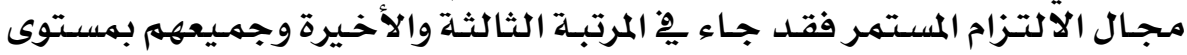

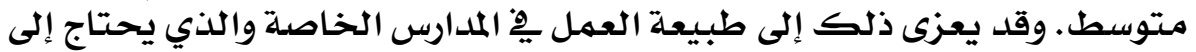

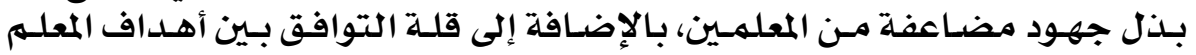

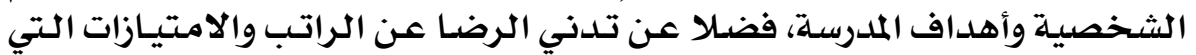

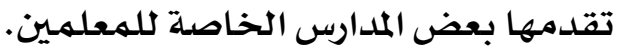

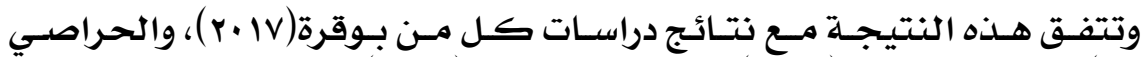

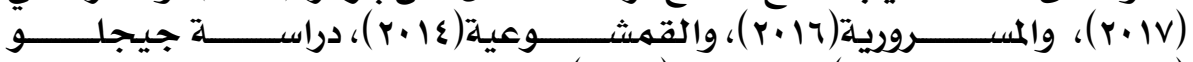

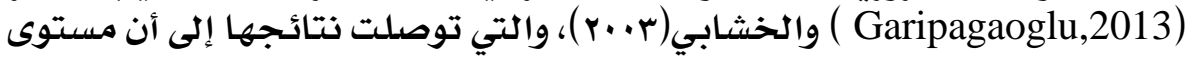

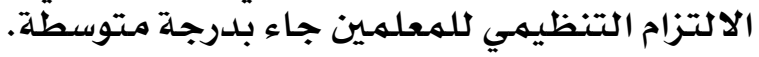
وتختلف هذه النتيـجة مـع نتائج دراسـة حنونة ( . . ) والتي أشـارت نتائجها إلى

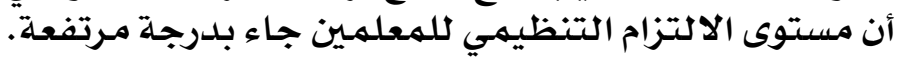

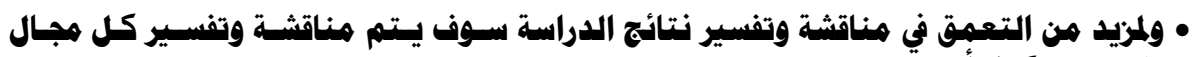

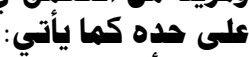

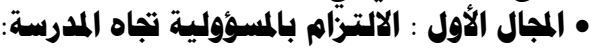

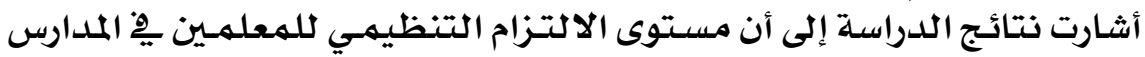

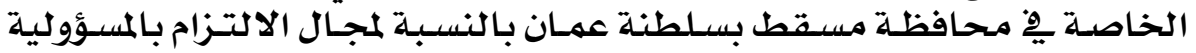

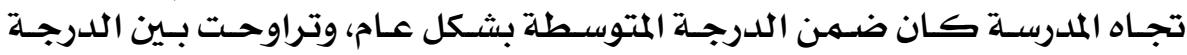




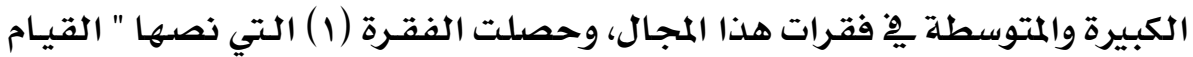

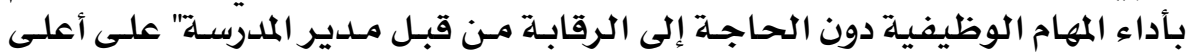

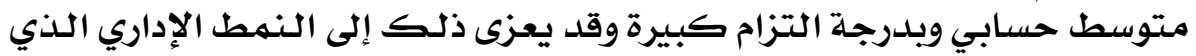

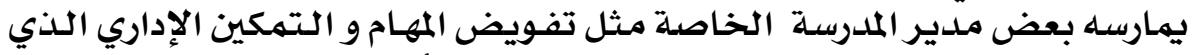

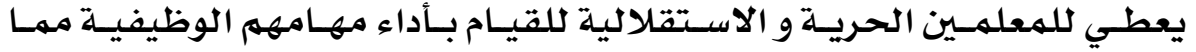

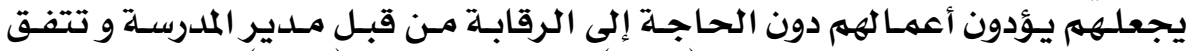

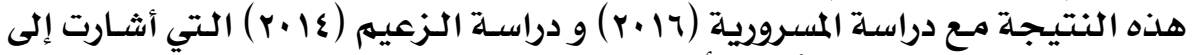

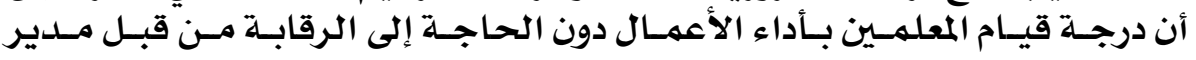

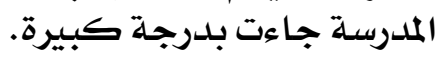

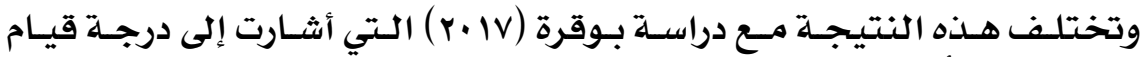

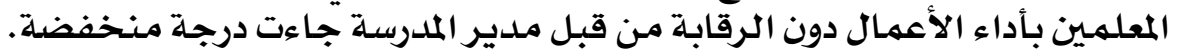

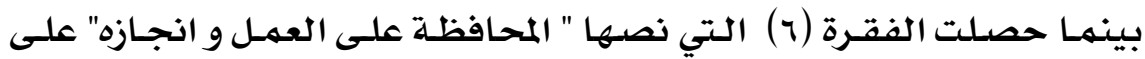

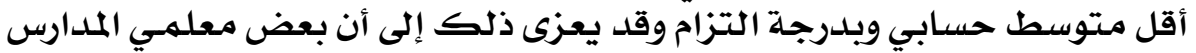

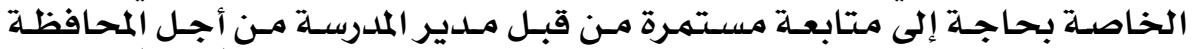

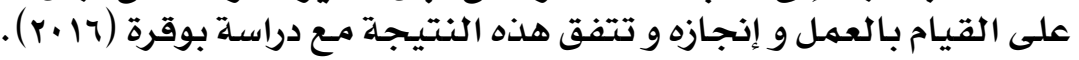

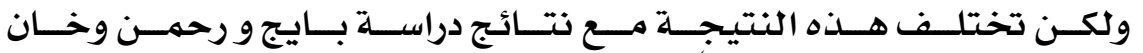
(Baig\&Rahman\&Khan,2012)

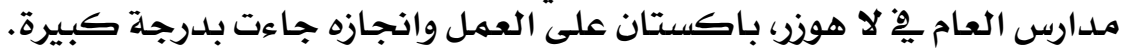

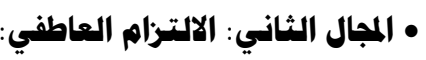

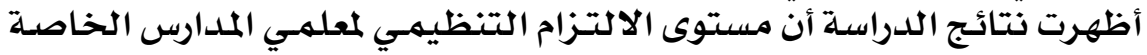

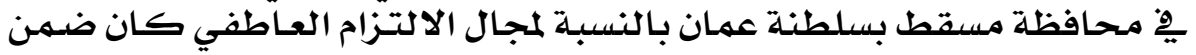

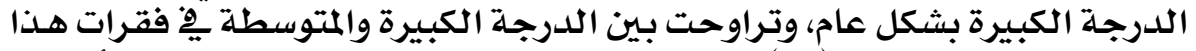

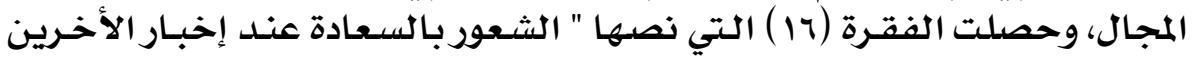

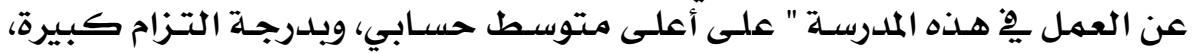

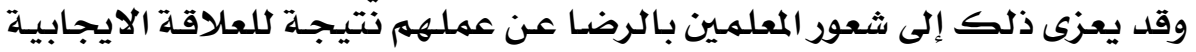

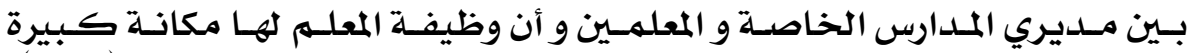

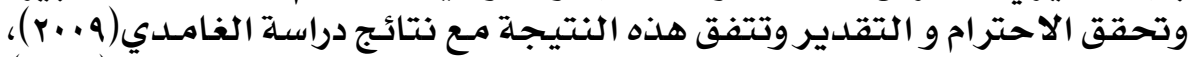

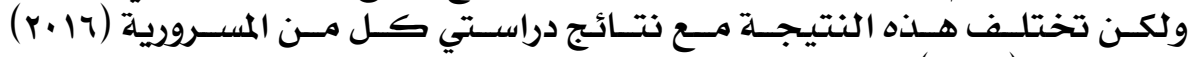

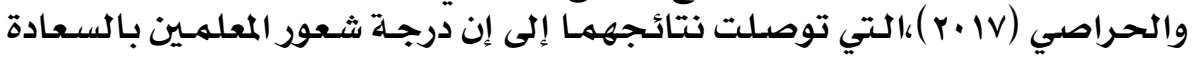

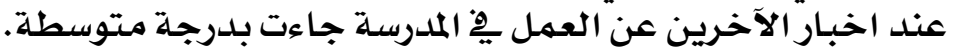

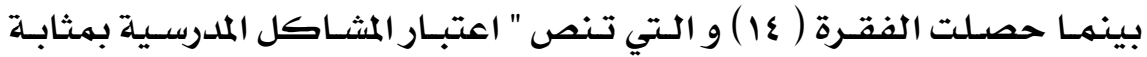

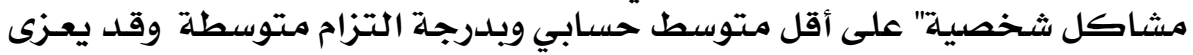

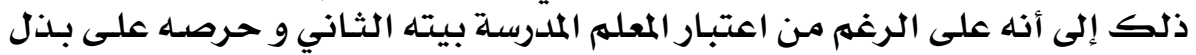

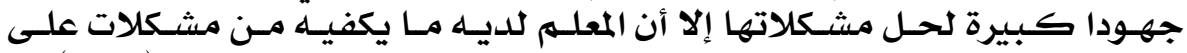






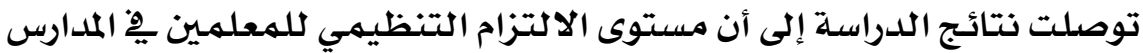

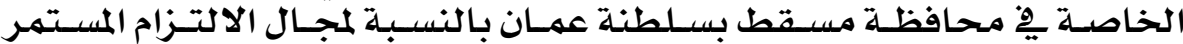

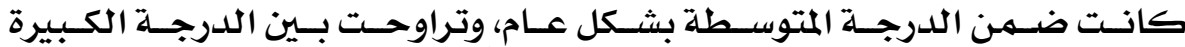

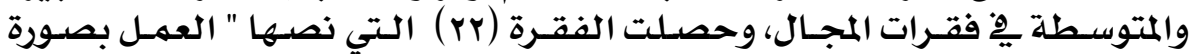

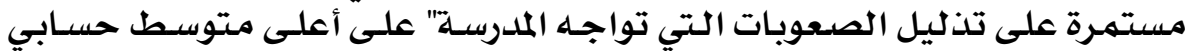

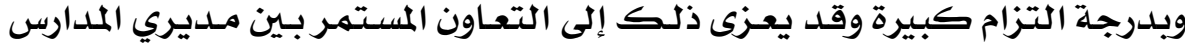

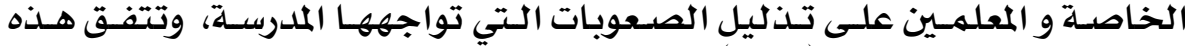

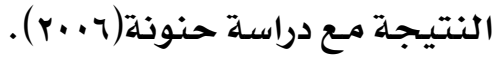

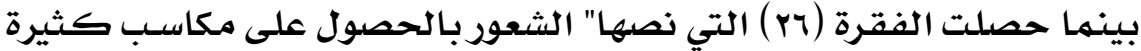

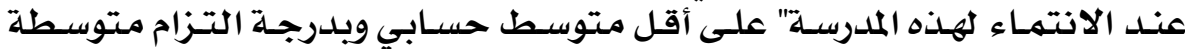

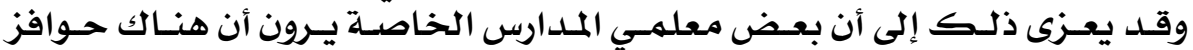

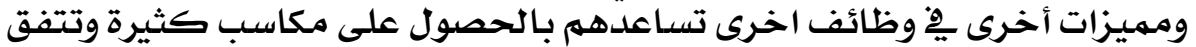

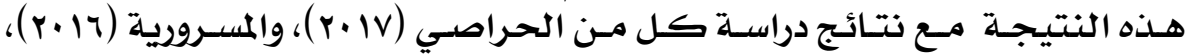

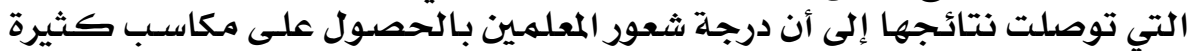

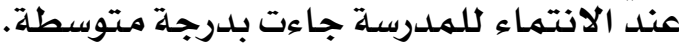

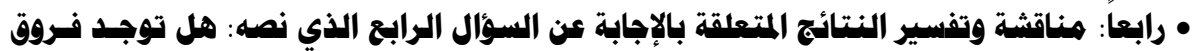
ذات دلالة احصائية عند هستوى الدلالة (

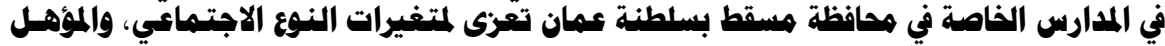

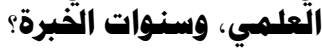

وسوف يتهم مناقشـة وتفسير نتائج كل متغير على حده على النحو الآتي:

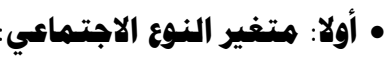

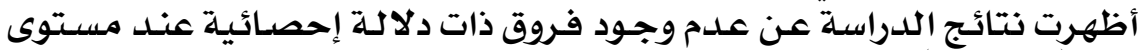

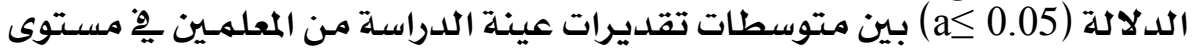

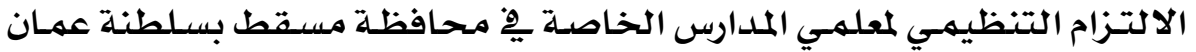

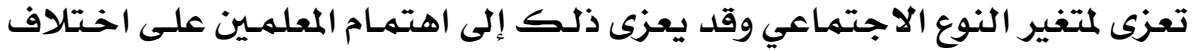

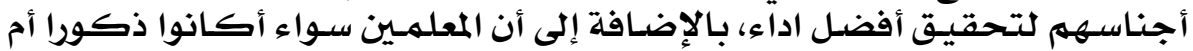

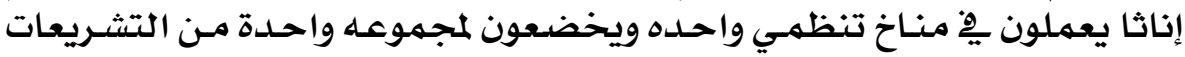

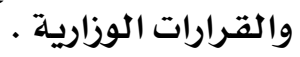

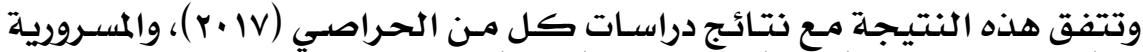

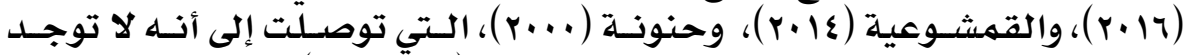

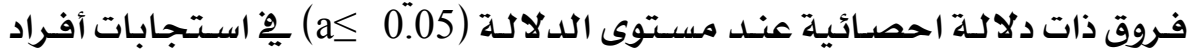
العينة تعزى لمتغير النوع الاجدة الاجتماعي.





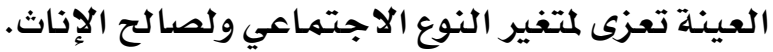




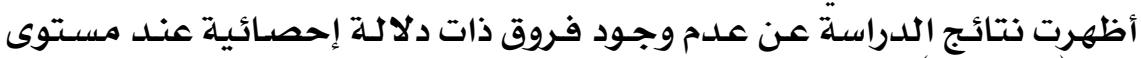

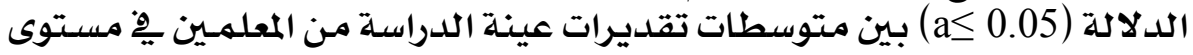

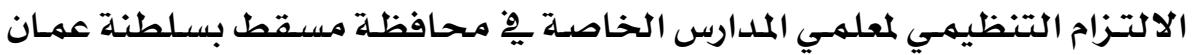

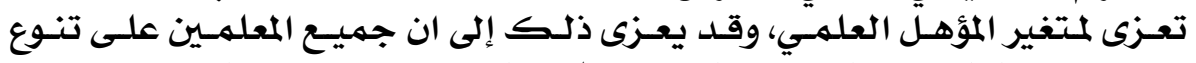

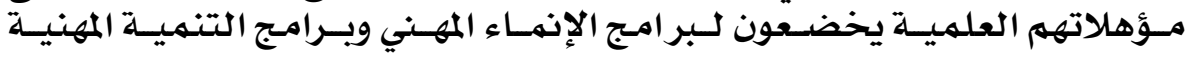
المستمرة التي تهدف إلى تطوير محارفهم ومهاراتهـه.

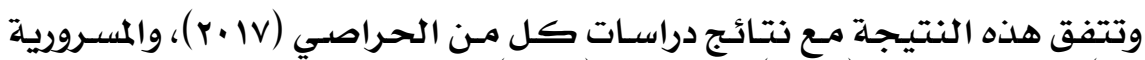

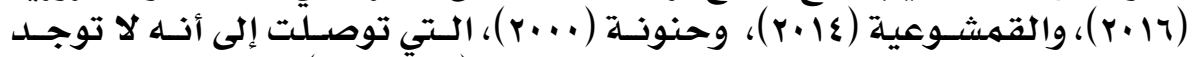

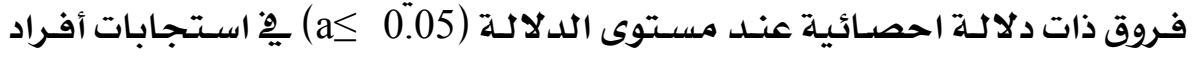
العينة تعزى لمتفير المؤهل العلمي.

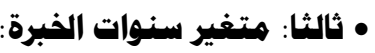

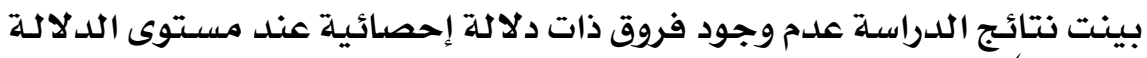

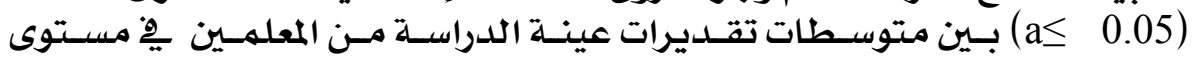

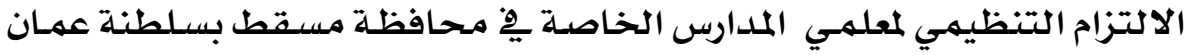

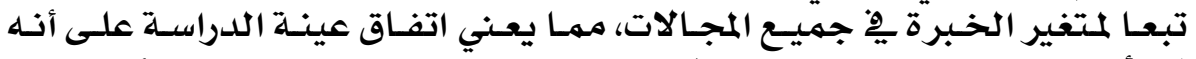

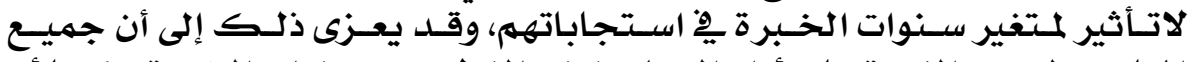

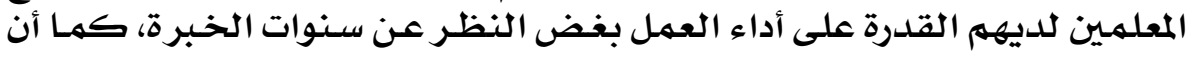

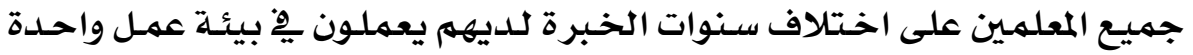
ويخضعون لبر امج تنميه مهنية مستمرة.

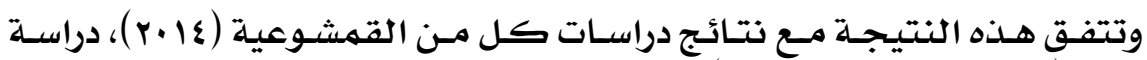

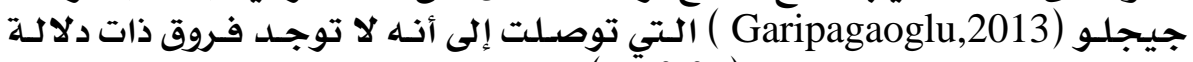
احصائية عند مستوى الدلالة (a

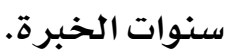

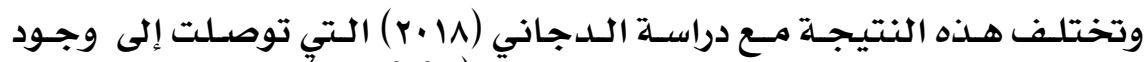

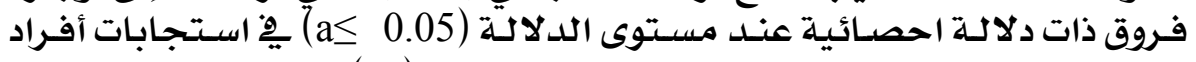

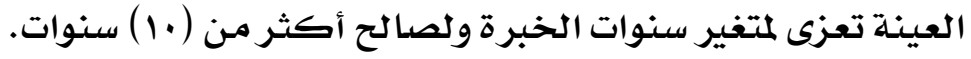

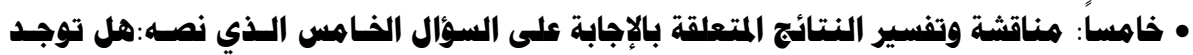

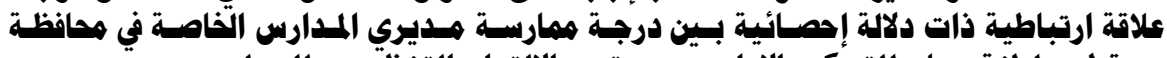

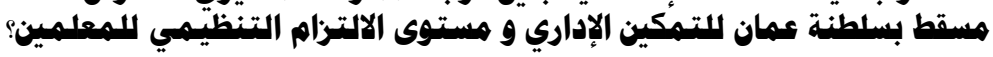

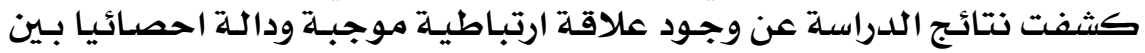

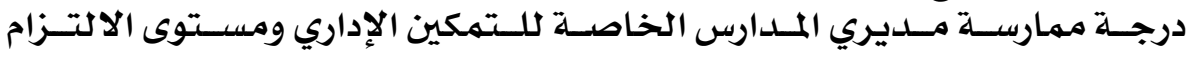

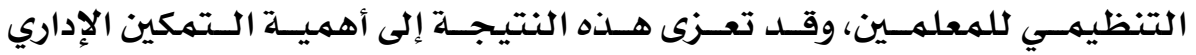

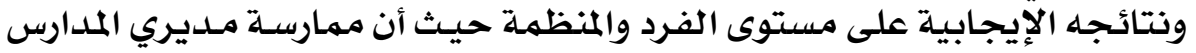

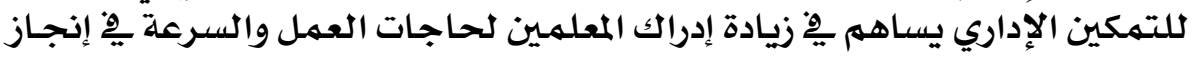

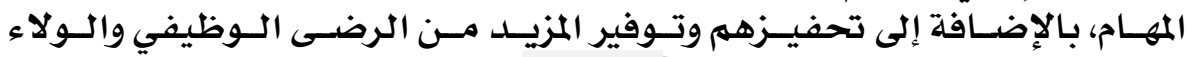




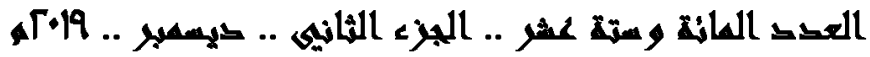

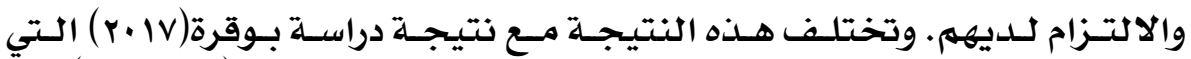

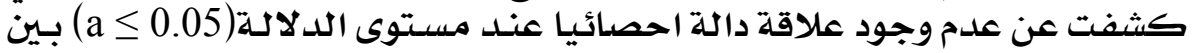
التمكين الإداري والالتزام التنظيهـي للمعحلمـين.

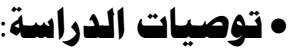

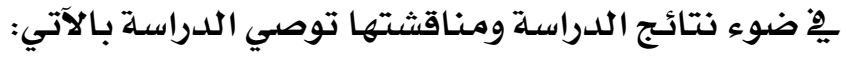

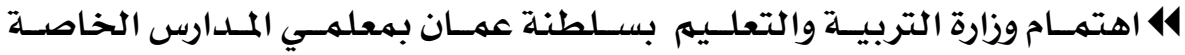

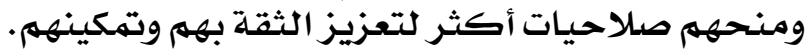

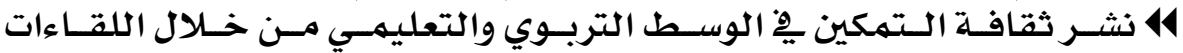

$$
\text { والنشرات والمواد التدريبية. }
$$

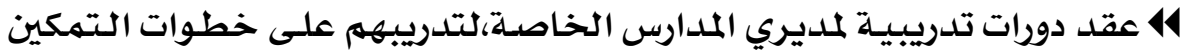

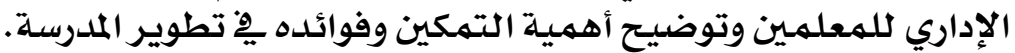

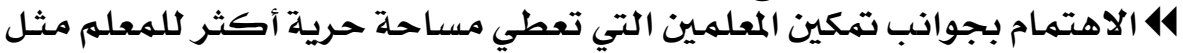

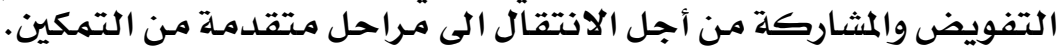

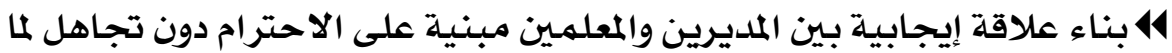

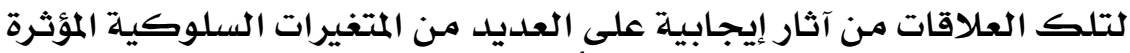

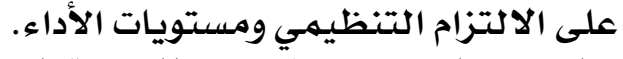

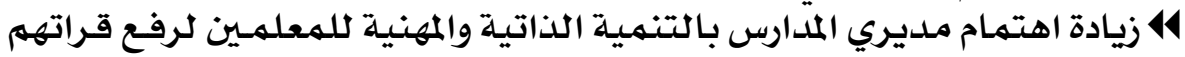

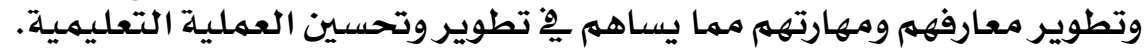

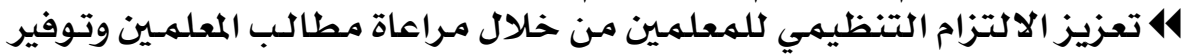

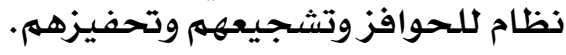

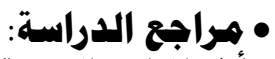

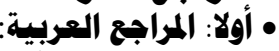

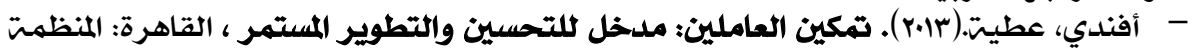

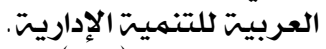

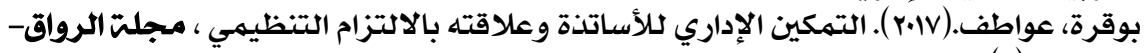

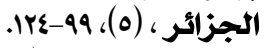

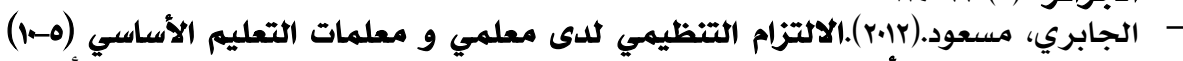

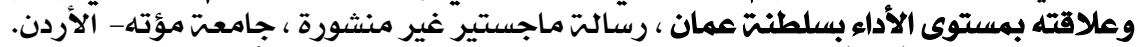

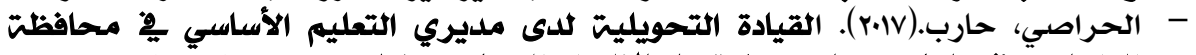

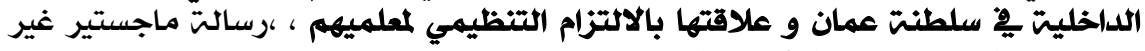

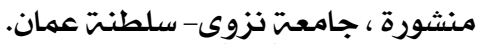

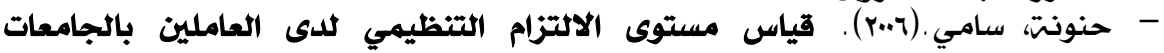

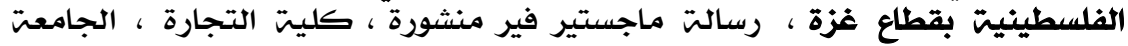
الإسلاميتش- غزة.

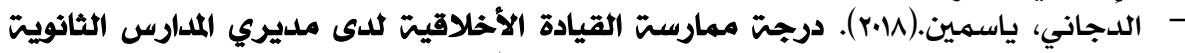

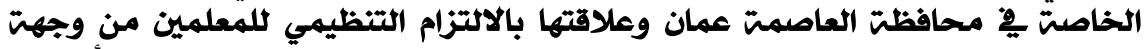

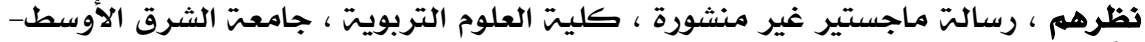

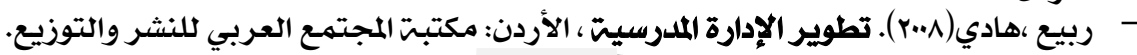




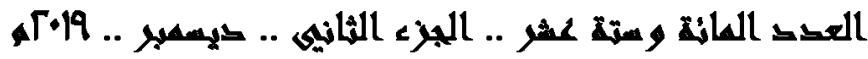

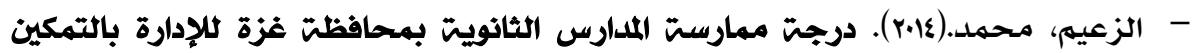

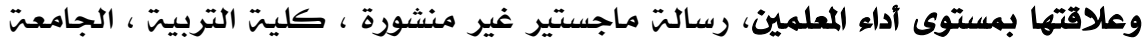

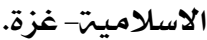

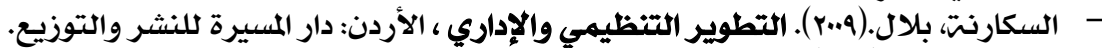

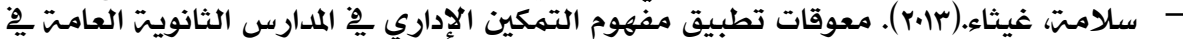

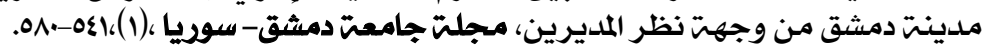

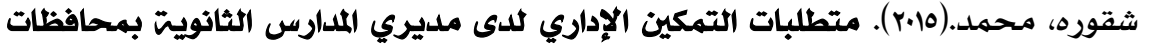

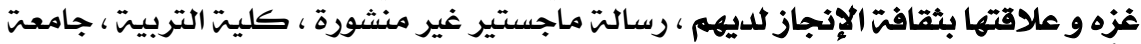

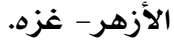

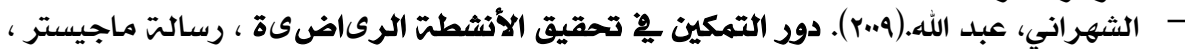



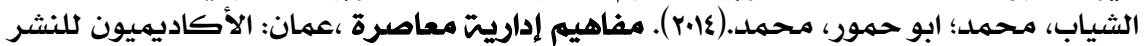

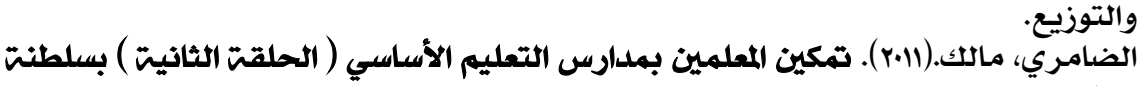

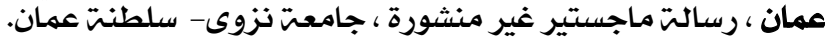

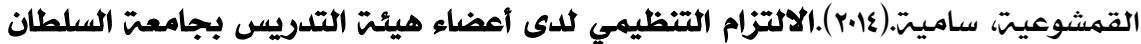

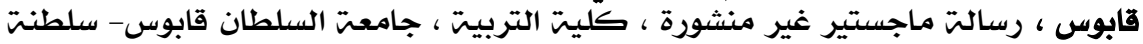
عمان.

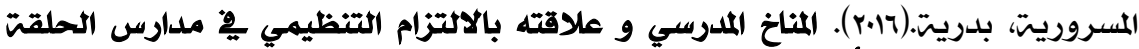

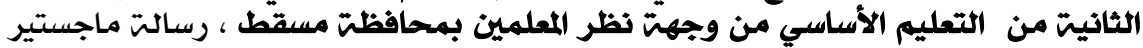

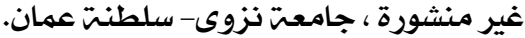

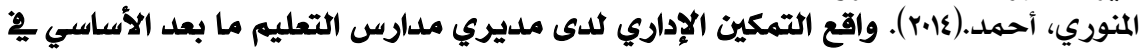

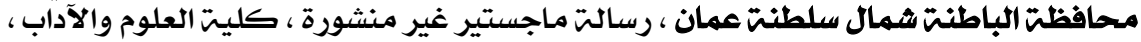
جامعت نزوى- سلطنت عمان.

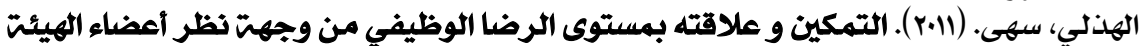

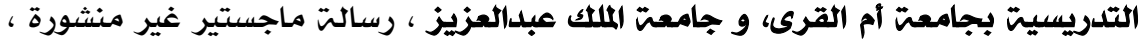

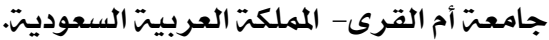

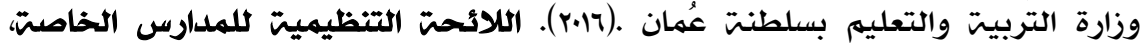
مسقط. وزارة التربيتة والتعليه بسلطنت عُمان. (19.r)، كتاب الإحصاء السنوي للعام الدراسي 19.r-

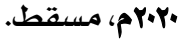

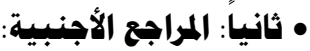

- Baig, M.A., Rehman,C.A. \& Khan,M.K. (2012). A study of the relationship Organizational commitment with participation in decision making, Procedural iustice and Organizational, Journal of Ouality and Technologv Management.8 (2), 4-25.

- Brown. B.B. (2003). Emplovee's organizational commitment And their perception of supervisors relations- oriented and task oriented leadership behavior. USA. Virginia polvtechnic institute.

- Eric. W. (2006). Teacher Empowerment as Perceived bv Principals in Hong Kong, Document Reproduction Services, Wayne State University. 


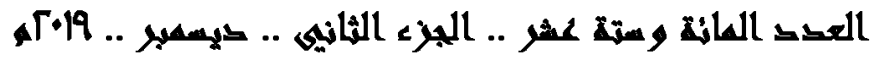

-Erlan, B. (2013). The Influence of Interpersonal Trust and Organizational Commitment on Perceived Organizational Performance, Journal of Applied Economics and Busines Research (JAEBR), 3 (3): 166-180.

- Garipagaoglu,B.(2013). Examining organizational commitment of private school teacher, Journal of Educational and Instructional Studies in The world.3(2), 22-28.

- Hung. C. J. (2005). A Correlational Study Between Junior High School Teacher Empowerment and Job Satisfaction in Kaohsiung Area of Taiwan. Theses \& Dissertations, University Of Incarnate Word.A.T.T.3193359.

- Lintner. J. (2008). The Relationship between Received Teacher Empowerment and principal Use of power, Degree of Doctor of Education of Auburn University.

- Luton. B. (2010). Transformational Leadership and OrganizationalCommitment: A study of UNC system business school department chairs, Ph.D. thesis. Capella University.

- Moye,M,Henkin, A,\&Egley,R,(2005).Teacher - principle Exploring Linkages between Empowerment \&Interpersonal Trust, Journal of Educational Adminlstration.43 (3), 260-277.

- Yao, Q., Chen, R., \& Cai, G. (2013). How internal marketing can cultivate psvchological empowerment and enhance employee performance. Social Behavior and Personality, 4(1), 529-538. 